\title{
Crystal Structure of the Intermediate $\mathrm{Na}_{2} \mathrm{~V}_{\mathbf{2}}\left(\mathrm{PO}_{4}\right)_{3}$ Phase and Electrochemical Reaction Mechanisms in $\mathrm{Na}_{x} \mathrm{~V}_{2}\left(\mathrm{PO}_{4}\right)_{3}(1 \leq \mathrm{x} \leq 4)$ System
}

\author{
Sunkyu Park ${ }^{1,2,3}$, Ziliang Wang ${ }^{4}$, Zeyu Deng ${ }^{4}$, lona Moog ${ }^{3}$, Pieremanuele \\ Canepa ${ }^{4,5^{*}}$, François Fauth ${ }^{6}$, Dany Carlier ${ }^{2,7}$, Laurence Croguennec ${ }^{2,7}$, \\ Christian Masquelier ${ }^{1,7}$ and Jean-Noël Chotard ${ }^{1,7, \&}$
}

${ }^{1}$ Laboratoire de Réactivité et de Chimie des Solides, Université de Picardie Jules Verne, CNRS-UMR 7314, F-80039 Amiens Cedex 1, France

${ }^{2}$ CNRS, Univ. Bordeaux, Bordeaux INP, ICMCB UMR 5026, F-33600 Pessac, France ${ }^{3}$ TIAMAT, 15 Rue Baudelocque, 80000 Amiens

${ }^{4}$ Department of Materials Science and Engineering, National University of Singapore, Singapore 117575, Singapore

${ }^{5}$ Chemical and Biomolecular Engineering, National University of Singapore, 4 Engineering Drive 4, Singapore 117585

${ }^{6}$ CELLS-ALBA Synchrotron, Cerdanyola del Vallès, E-08290 Barcelona, Spain ${ }^{7} R S 2 E$, Réseau Français sur le Stockage Electrochimique de l'Energie, FR CNRS 3459,

F-80039 Amiens Cedex 1, France

Corresponding authors:

* pcanepa@nus.edu.sg

\& jean-noel.chotard@u-picardie.fr 


\section{Abstract}

The Na-superionic-conductor (NASICON) $\mathrm{Na}_{3} \mathrm{~V}_{2}\left(\mathrm{PO}_{4}\right)_{3}$ is an important positive electrode material for Na-ion batteries. Here, we investigate the mechanisms of phase transition in $\mathrm{Na}_{x} \mathrm{~V}_{2}\left(\mathrm{PO}_{4}\right)_{3}(1 \leq \mathrm{x} \leq 4)$ upon a non-equilibrium battery cycling. Unlike the widely believed two-phase reaction in $\mathrm{Na}_{3} \mathrm{~V}_{2}\left(\mathrm{PO}_{4}\right)_{3}-\mathrm{Na}_{1} \mathrm{~V}_{2}\left(\mathrm{PO}_{4}\right)_{3}$ system, we determine a new intermediate $\mathrm{Na}_{2} \mathrm{~V}_{2}\left(\mathrm{PO}_{4}\right)_{3}$ phase using operando synchrotron X-ray diffraction. Density functional theory calculations further support the existence of the $\mathrm{Na}_{2} \mathrm{~V}_{2}\left(\mathrm{PO}_{4}\right)_{3}$ phase. We propose for the first time two possible crystal structures of $\mathrm{Na}_{2} \mathrm{~V}_{2}\left(\mathrm{PO}_{4}\right)_{3}$ analyzed by Rietveld refinement. The two structure models with the space groups $P 2_{1} / c$ or $P 2 / C$ for the new intermediate $\mathrm{Na}_{2} \mathrm{~V}_{2}\left(\mathrm{PO}_{4}\right)_{3}$ phase show similar unit cell parameters but different atomic arrangements, including a vanadium charge ordering. As the appearance of the intermediate $\mathrm{Na}_{2} \mathrm{~V}_{2}\left(\mathrm{PO}_{4}\right)_{3}$ phase is accompanied by symmetry reduction, $\mathrm{Na}(1)$ and $\mathrm{Na}(2)$ sites split into several positions in $\mathrm{Na}_{2} \mathrm{~V}_{2}\left(\mathrm{PO}_{4}\right)_{3}$, in which one of the splitting $\mathrm{Na}(2)$ position is found to be a vacancy whereas the $\mathrm{Na}(1)$ positions are almost fully filled. The intermediate $\mathrm{Na}_{2} \mathrm{~V}_{2}\left(\mathrm{PO}_{4}\right)_{3}$ phase reduces the lattice mismatch between $\mathrm{Na}_{3} \mathrm{~V}_{2}\left(\mathrm{PO}_{4}\right)_{3}$ and $\mathrm{Na}_{1} \mathrm{~V}_{2}\left(\mathrm{PO}_{4}\right)_{3}$ phases facilitating a fast phase transition. This work paves the way for a better understanding of great rate capabilities of $\mathrm{Na}_{3} \mathrm{~V}_{2}\left(\mathrm{PO}_{4}\right)_{3}$.

Keywords: crystal structure, $\mathrm{Na}_{2} \mathrm{~V}_{2}\left(\mathrm{PO}_{4}\right)_{3}$, phase transition, intermediate phase, metastable, non-equilibrium, operando X-ray diffraction, density functional theory calculations 


\section{Introduction}

Na-superionic-conductor (NASICON) structured materials are considered as promising electrodes for sodium-ion batteries because of their 3D open-framework crystal structure, resulting in high cyclability and fast rate capability. ${ }^{1-5}$ Among them, $\mathrm{Na}_{3} \mathrm{~V}_{2}\left(\mathrm{PO}_{4}\right)_{3}$ has been extensively studied, showing satisfactory energy density and rate performance as well as good thermal stability. ${ }^{6-13}$ The crystal structure of $\mathrm{Na}_{3} \mathrm{~V}_{2}\left(\mathrm{PO}_{4}\right)_{3}$ is composed of repeating units called lanterns, into which two $\mathrm{VO}_{6}$ octahedra are joined together through three corner-sharing $\mathrm{PO}_{4}$ tetrahedra. Within the 3D framework generated by these lanterns, two crystallographic sodium sites, labeled $\mathrm{Na}(1)$ and $\mathrm{Na}(2)$, are usually reported. The $\mathrm{Na}(1)$ site is located between the lantern units along the [001] $]_{\text {hexagonal }}$ direction and is surrounded by six oxygen atoms in its first coordination sphere and by six $\mathrm{Na}(2)$ atoms in its second one. At maximum, the $\mathrm{Na}(1)$ and $\mathrm{Na}(2)$ sites (of different multiplicities) can respectively generate one and three $\mathrm{Na}$ positions per formula unit, thus leading to the final stoichiometry $\mathrm{Na}_{4} \mathrm{~V}_{2}\left(\mathrm{PO}_{4}\right)_{3}$. During electrochemical reactions, although the $\mathrm{Na}(1)$ site is involved in the global $\mathrm{Na}$-ion transport mechanism $(\mathrm{Na}(2)-\mathrm{Na}(1)-\mathrm{Na}$ (2) pathways), it tends to be almost fully occupied regardless of the total $\mathrm{Na}$ content into the material, whereas the $\mathrm{Na}(2)$ site is partially/fully emptied or filled depending on the compositions. . $^{8,9,14-16}$

It is well known that two $\mathrm{Na}^{+}$ions can be reversibly electrochemically extracted from a $\mathrm{Na}_{3} \mathrm{~V}_{2}\left(\mathrm{PO}_{4}\right)_{3}$ electrode, through a voltage-composition "plateau" at $\sim 3.4 \mathrm{~V}$ (vs. $\mathrm{Na}^{+} / \mathrm{Na}$ ) utilizing the $\mathrm{V}^{4+/ 3+}$ redox couple (with a theoretical capacity of $117.6 \mathrm{mAh} / \mathrm{g}$ ). ${ }^{13,17-22}$ The reaction has been described by many authors as a mechanism of two-phase reaction between $\mathrm{Na}_{3} \mathrm{~V}_{2}{ }^{3+}\left(\mathrm{PO}_{4}\right)_{3}$ and $\mathrm{Na}_{1} \mathrm{~V}_{2}{ }^{4+}\left(\mathrm{PO}_{4}\right)_{3} \cdot{ }^{13,17-22}$ Additionally, one $\mathrm{Na}^{+}$ion can be inserted into $\mathrm{Na}_{3} \mathrm{~V}_{2}\left(\mathrm{PO}_{4}\right)_{3}$ at $\sim 1.6 \mathrm{~V}$ (vs. $\mathrm{Na}^{+} / \mathrm{Na}$ ) through the $\mathrm{V}^{3+/ 2+}$ redox couple towards the $\mathrm{Na}_{4} \mathrm{~V}_{2}\left(\mathrm{PO}_{4}\right)_{3}$ composition (theoretical capacity of $58.8 \mathrm{mAh} / \mathrm{g}$ ). ${ }^{18,19,22-27}$ Recently, Zakharkin et al. ${ }^{20}$ noticed the signature of an intermediate $\mathrm{Na}_{2} \mathrm{~V}_{2}\left(\mathrm{PO}_{4}\right)_{3}$ phase, which involves the $\mathrm{V}^{4+/ 3+}$ redox couple. Nevertheless, no structural information on the intermediate phase was provided. Other previous reports also suggested the existence of $\mathrm{Na}_{2} \mathrm{~V}_{2}\left(\mathrm{PO}_{4}\right)_{3}$, but the authors barely contemplated the existence of a new intermediate phase. ${ }^{18,19}$ This suggests 
that the widely believed two-phase reaction between $\mathrm{Na}_{3} \mathrm{~V}_{2}\left(\mathrm{PO}_{4}\right)_{3}$ and $\mathrm{Na}_{1} \mathrm{~V}_{2}\left(\mathrm{PO}_{4}\right)_{3}$ needs to be reinvestigated, in particular, providing structural information and the origin of the appearance of the intermediate $\mathrm{Na}_{2} \mathrm{~V}_{2}\left(\mathrm{PO}_{4}\right)_{3}$ phase.

Here, we elucidate the mechanisms of phase transition of the $\mathrm{Na}_{3} \mathrm{~V}_{2}\left(\mathrm{PO}_{4}\right)_{3}-\mathrm{Na}_{1} \mathrm{~V}_{2}\left(\mathrm{PO}_{4}\right)_{3}$ system including the intermediate $\mathrm{Na}_{2} \mathrm{~V}_{2}\left(\mathrm{PO}_{4}\right)_{3}$ phase, utilizing $\mathrm{V}^{4+/ 3+}$ redox couple. We also investigate the $\mathrm{Na}_{3} \mathrm{~V}_{2}\left(\mathrm{PO}_{4}\right)_{3}-\mathrm{Na}_{4} \mathrm{~V}_{2}\left(\mathrm{PO}_{4}\right)_{3}$ system involving the $\mathrm{V}^{3+/ 2+}$ redox couple. The intermediate $\mathrm{Na}_{2} \mathrm{~V}_{2}\left(\mathrm{PO}_{4}\right)_{3}$ phase was detected by operando $\mathrm{X}$-ray synchrotron diffraction as well as predicted by theoretical calculations. Here, we report for the first time on the crystal structure of the $\mathrm{Na}_{2} \mathrm{~V}_{2}\left(\mathrm{PO}_{4}\right)_{3}$ phase, compared in detail with those of $\mathrm{Na}_{x} \mathrm{~V}_{2}\left(\mathrm{PO}_{4}\right)_{3}(x=1,3$, 4). The intermediate $\mathrm{Na}_{2} \mathrm{~V}_{2}\left(\mathrm{PO}_{4}\right)_{3}$ phase appears as reducing the lattice mismatch between $\mathrm{Na}_{3} \mathrm{~V}_{2}\left(\mathrm{PO}_{4}\right)_{3}$ and $\mathrm{Na}_{1} \mathrm{~V}_{2}\left(\mathrm{PO}_{4}\right)_{3}$ phases, and as the $\mathrm{Na}(1)$ and $\mathrm{Na}(2)$ sites split into several positions with different $\mathrm{Na}^{+}$distributions, including vacancies. This study is highly relevant to better understand the behavior of fast-rate electrode materials that display transient phases, such as the intermediate $\mathrm{Li}_{x} \mathrm{FePO}_{4}$ phases $(x=0.6-0.75)$ detected during nonequilibrium battery operations. ${ }^{28-36}$

\section{Experimental}

Synthesis: The carbon-coated $\mathrm{Na}_{3} \mathrm{~V}_{2}\left(\mathrm{PO}_{4}\right)_{3}$ was prepared by a sol-gel-assisted solid-state reaction. $\mathrm{Na}_{2} \mathrm{CO}_{3}$ (Sigma-Aldrich, $99.5 \%$ ), $\mathrm{C}_{10} \mathrm{H}_{14} \mathrm{O}_{5} \mathrm{~V}$ (Sigma-Aldrich, 97\%), $\mathrm{NH}_{4} \mathrm{H}_{2} \mathrm{PO}_{4}$ (Sigma-Aldrich, 98.5\%), and citric acid (Alfa Aesar, $99 \%$ ) in a molar ratio of 1.5:2:3:2, were dissolved in deionized water and ethanol (50/50 by volume). The solution was stirred overnight at $80{ }^{\circ} \mathrm{C}$ in an oil bath before being dried in oven. The obtained powder was ground and pre-heated at $400{ }^{\circ} \mathrm{C}$ for $4 \mathrm{~h}$ in Ar. The resulting powder was then mixed in a mortar and annealed at $700{ }^{\circ} \mathrm{C}$ for $10 \mathrm{~h}$ under $\mathrm{Ar} / \mathrm{H}_{2}$ (95/5) atmosphere.

Material Characterization: The chemical composition of the synthesized material was quantified using inductively coupled plasma-optical emission spectroscopy (ICP-OES) with a Varian Model 720-ES spectrometer. The amount of carbon coating on the synthesized 
material was measured by thermogravimetric analyses (TGA) with a NETZSCH STA 449C. The morphology of the powder was examined by scanning electron microscopy (SEM) with a Hitachi Model S-4500 microscope.

Operando Synchrotron X-ray Diffraction: Operando synchrotron X-ray powder diffraction (SXRPD) measurements were performed on the MSPD beamline of the ALBA synchrotron in Spain $^{37}$ with Debye-Scherrer geometry $(\lambda=0.8266 \AA)$ using an in situ coin cell with glass windows. Prior to the operando measurements, the SXRPD pattern of the pristine $\mathrm{Na}_{3} \mathrm{~V}_{2}\left(\mathrm{PO}_{4}\right)_{3}$ was collected with a $0.3 \mathrm{~mm}$ diameter capillary. Two in situ cells containing $\mathrm{Na}_{3} \mathrm{~V}_{2}\left(\mathrm{PO}_{4}\right)_{3}$ electrodes were measured at the same time thanks to the eight-cells holder with an automatic positioning system available at the MSPD beamline. ${ }^{38}$ Each SXRPD pattern was collected every 30 minutes with an acquisition time of $\sim 3.5$ minutes in the $2 \theta$ angular range of $2-40^{\circ}$, with a $2 \theta$ step size of $0.006^{\circ}$ using a MYTHEN detector for rapid pattern collection. The working electrodes were composed of the $\mathrm{Na}_{3} \mathrm{~V}_{2}\left(\mathrm{PO}_{4}\right)_{3}$ powder and carbon black (80/20 in wt\%), and Na metal was used as counter/reference electrode. The mass loadings of the active material in the electrodes were 5.33 and $6.12 \mathrm{mg}$, respectively. One sheet of Whatman glass fiber (GF/D) was used as a separator and the electrolyte was composed of $1 \mathrm{M} \mathrm{NaPF}_{6}$ in ethylene carbonate (EC) / dimethyl carbonate (DMC) $(1: 1, \mathrm{w} / \mathrm{w})$ with 2 wt.\% of fluoroethylene carbonate (FEC). The first cell was measured for one cycle with a slow electrochemical reaction rate of $0.11 \mathrm{C}(1 \mathrm{C}=58.2 \mathrm{~mA} / \mathrm{g}$, or about $9 \mathrm{~h}$ for the exchange of $1 \mathrm{Na}^{+} / 1 \mathrm{e}^{-}$) with a voltage window of $1-3.75 \mathrm{~V}$ versus $\mathrm{Na}^{+} / \mathrm{Na}$. The second cell was measured for six cycles with higher C-rates (i.e., 0.37-0.77-0.77-0.77-0.37-0.77 C). A large overpotential was observed during the measurements of the second cell, hence the voltage windows were adjusted with the respected C-rates (detailed cycling conditions can be found in Table S1 in the supporting information section).

Density Functional Theory Calculations: To assess the thermodynamic stability of $\mathrm{Na}_{\mathrm{x}} \mathrm{V}_{2}\left(\mathrm{PO}_{4}\right)_{3}$ with distinct Na-vacancy orderings at $0 \mathrm{~K}$, we used the spin-polarized density functional theory (DFT), as implemented in VASP. ${ }^{39,40}$ The exchange-correlation was approximated by the strongly constrained and appropriately normed (SCAN) meta- 
generalized gradient approximation functional, ${ }^{41}$ with a $U$ correction of $1.0 \mathrm{eV}$ on all vanadium atoms to improve the localization of $3 d$ electrons. ${ }^{42}$ The total energies were converged to within $10^{-5} \mathrm{eV} / \mathrm{cell}$, atomic forces (stresses) within $10^{-2} \mathrm{eV} / \AA ̊(0.29 \mathrm{GPa})$. The $1^{\text {st }}$ Brillouin zone was integrated over a $\Gamma$-centered $k$-point grid of $3 \times 3 \times 3$ for all primitive structures containing 2 formula units (f.u.) with 42 atoms, a $1 \times 3 \times 3 k$-point mesh for all supercells with 4 f.u. ( 84 atoms), and a $1 \times 1 \times 3$ mesh for 8 f.u. (168 atoms). The valence electrons were treated in terms of plane-waves up to an energy cutoff of $520 \mathrm{eV}$, while projector augmented wave potentials were used to describe the core electrons, ${ }^{43}$ with $\mathrm{Na}$ $3 s^{1}, \mathrm{~V} \_$pv $3 p^{6} 3 d^{4} 4 s^{1}, \mathrm{P} 2 s^{2} 3 p^{3}, \mathrm{O} 2 s^{2} 2 p^{4}$.

The average intercalation voltage was derived using Eq. 1.

$$
V=-\frac{\Delta G^{0}}{y F} \approx-\frac{E\left(\mathrm{Na}_{x+y} \mathrm{~V}_{2}\left(\mathrm{PO}_{4}\right)_{3}\right)-\left[E\left(\mathrm{Na}_{x} \mathrm{~V}_{2}\left(\mathrm{PO}_{4}\right)_{3}\right)+y \mu_{N a}\right]}{y F}
$$

where $\Delta G^{0}$ is the change of Gibbs free energy, as approximated from our DFT total energies, which ignore the zero-point energy correction, the $p V$ term, and entropic effects. Thus, $E\left(\mathrm{Na}_{x+y} \mathrm{~V}_{2}\left(\mathrm{PO}_{4}\right)_{3}\right), E\left(\mathrm{Na}_{x} \mathrm{~V}_{2}\left(\mathrm{PO}_{4}\right)_{3}\right)$ and $\mu_{N a}$ are the DFT total energies of stable $\mathrm{Na}$ vacancy orderings at compositions $x$ and $x+y$, and the $\mathrm{Na}$ chemical potential of $\mathrm{Na}$ metal, respectively. $F$ is the Faraday constant. Mixing enthalpies $\left(H_{\text {mixing }}\right)$ at different $\mathrm{Na}$ compositions, to construct the $0 \mathrm{~K}$ phase diagram were defined in Eq. 2.

$$
\begin{aligned}
H_{\text {mixing }}(x) \approx & E\left[\mathrm{Na}_{x} \mathrm{~V}_{2}\left(\mathrm{PO}_{4}\right)_{3}\right]-\left(\frac{4-x}{3}\right) E\left[\mathrm{Na}_{1} \mathrm{~V}_{2}\left(\mathrm{PO}_{4}\right)_{3}\right] \\
& -\left(\frac{x-1}{3}\right) E\left[\mathrm{Na}_{4} \mathrm{~V}_{2}\left(\mathrm{PO}_{4}\right)_{3}\right]
\end{aligned}
$$




\section{Results and Discussion}

The composition of the as-synthesized $\mathrm{Na}_{3} \mathrm{~V}_{2}\left(\mathrm{PO}_{4}\right)_{3}$ powder was determined by elemental analysis using ICP-OES. The Na/V/P ratio was found to be 3.03(2):1.97(3):2.99(6), suggesting that the target composition $\mathrm{Na}_{3} \mathrm{~V}_{2}\left(\mathrm{PO}_{4}\right)_{3}$ was achieved through the sol-gel-assisted solidstate reaction. SEM images of the $\mathrm{Na}_{3} \mathrm{~V}_{2}\left(\mathrm{PO}_{4}\right)_{3}$ powder (Figure S1) show that the particles have no particular shapes as similar to other studies. ${ }^{11-13,17-22}$ However, relatively large agglomerates ranging from few microns to several tenths of microns were found with the primary particles in the size of a few hundreds of nanometers. The powder is carbon-coated on the surface, ca. $9 \mathrm{wt} \%$ of carbon as determined by TGA measurements in air, shown in Figure S2.

The SXRPD pattern of the as-synthesized $\mathrm{Na}_{3} \mathrm{~V}_{2}\left(\mathrm{PO}_{4}\right)_{3}$ powder is shown in Figure 1. No impurity phases were detected based on the XRD analysis. As previously reported, ${ }^{44}$ at room temperature the crystal structure of $\mathrm{Na}_{3} \mathrm{~V}_{2}\left(\mathrm{PO}_{4}\right)_{3}$ cannot be indexed using a rhombohedral ( $R 3 C$ ) cell, but a monoclinic distortion must be considered. This is illustrated by the splitting

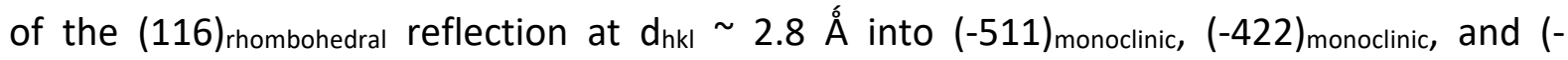
313) monoclinic, which are signatures of the monoclinic distortion (inset images of Figure 1). Depending on the thermal history of the sample, $\mathrm{Na}_{3} \mathrm{~V}_{2}\left(\mathrm{PO}_{4}\right)_{3}$ can crystallize either in the monoclinic $\alpha$ or $\beta$ form at room temperature (the reversible phase transition occurring very close to room temperature with about $10^{\circ}$ of hysteresis)..$^{44}$ In the present study, the crystal structure was refined with the monoclinic $\beta$ phase since the (111) reflection at $6.74^{\circ}$ $\left(\lambda=0.8266 \AA\right.$ ) was not observed, while it is allowed in the $\alpha$ (i.e., $\mathrm{Na}^{+}$ordered) phase, as shown in Figure S3. The refined cell parameters using the Rietveld method are $a=15.4104(4)$ $\AA$, $b=8.7288(2) \AA, c=8.8257(2) \AA, b=126.1202(17)^{\circ}$, and $V / Z=239.75(2) \AA^{3}$ with the space group $C 2 / c$. The weak unindexed satellite reflections at low angles are attributed to an incommensurate modulated structure. These modulations originate both from the occupancies and the positions of $\mathrm{Na}^{+}$ions in $\mathrm{Na}_{3} \mathrm{~V}_{2}\left(\mathrm{PO}_{4}\right)_{3}$. No detailed structural study of the incommensurate $\beta$ phase has been reported yet and thus the SXRPD pattern was refined without modulation vectors. 


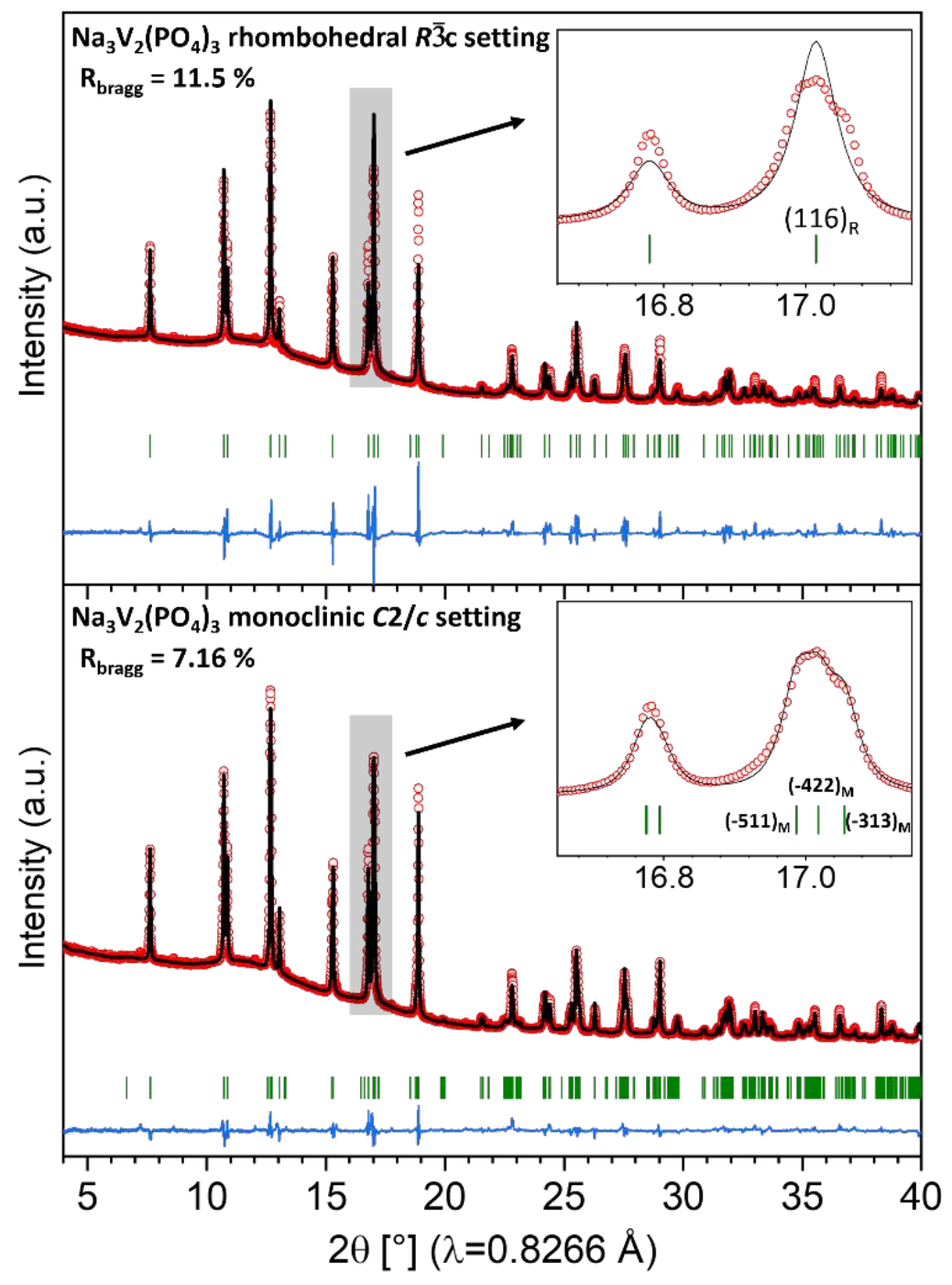

Figure 1. Rietveld refinement results of the as-synthesized $\mathrm{Na}_{3} \mathrm{~V}_{2}\left(\mathrm{PO}_{4}\right)_{3}$ powder with (top) the space group $R 3 c$ and (bottom) the space group $C / 2 c$. The corresponding SXRPD pattern was collected at $298 \mathrm{~K}$. It clearly shows that the structure of $\mathrm{Na}_{3} \mathrm{~V}_{2}\left(\mathrm{PO}_{4}\right)_{3}$ contains a monoclinic distortion as, for instance, $(116)_{R}$ reflection splits into $(-511)_{M},(-422)_{M}$, and $(-313)_{M}(R$ and $M$ here stand for rhombohedral and monoclinic, respectively).

To study the (de-)intercalated phases and the $\mathrm{Na}^{+}$insertion/extraction mechanisms in $\mathrm{Na}_{3} \mathrm{~V}_{2}\left(\mathrm{PO}_{4}\right)_{3}$, operando SXRPD measurements were performed. Figure 2a displays a 2D view of the SXRPD of a selected $2 \theta$ range during the first electrochemical charge-discharge cycle together with the corresponding galvanostatic data measured within a voltage window of $1.0-3.75 \mathrm{~V}$ (vs. $\mathrm{Na}^{+} / \mathrm{Na}$ ) at a C-rate of $\sim 0.11 \mathrm{C}$ (for wider $2 \theta$ range, see Figure S4). A total number of 89 scans were recorded during the first cycle. From scan number 1 to 30, 
$\mathrm{Na}_{3} \mathrm{~V}_{2}\left(\mathrm{PO}_{4}\right)_{3}$ is first oxidized up to $3.75 \mathrm{~V}$ vs. $\mathrm{Na}^{+} / \mathrm{Na}$. During the charge process, two $\mathrm{Na}^{+}$ cations are extracted leading to the composition $\mathrm{Na}_{1} \mathrm{~V}_{2}\left(\mathrm{PO}_{4}\right)_{3}$. Close to the mid-charge (i.e., after approximatively $10 \mathrm{~h}$ of cycling) a weak reflection at $2 \theta \approx 7.7^{\circ}$ starts to appear together with the presence of $\mathrm{Na}_{3} \mathrm{~V}_{2}\left(\mathrm{PO}_{4}\right)_{3}$ (corresponding reflection at $2 \theta \approx 7.63^{\circ}$ ) and $\mathrm{Na}_{1} \mathrm{~V}_{2}\left(\mathrm{PO}_{4}\right)_{3}$ (corresponding reflection at $\left.2 \theta \approx 7.85^{\circ}\right) . \mathrm{Na}_{1} \mathrm{~V}_{2}\left(\mathrm{PO}_{4}\right)_{3}$ is then reduced back to $\mathrm{Na}_{3} \mathrm{~V}_{2}\left(\mathrm{PO}_{4}\right)_{3}$ (scan number 60) and further to $\mathrm{Na}_{4} \mathrm{~V}_{2}\left(\mathrm{PO}_{4}\right)_{3}$ (scan number 89 ) at a potential of $\sim 1 \mathrm{~V}$ vs. $\mathrm{Na}^{+} / \mathrm{Na}$. During the discharge process, the very same peak at $2 \theta \approx 7.7^{\circ}$ re-appears with an increased intensity. This new reflection that is attributed to the new intermediate $\mathrm{Na}_{2} \mathrm{~V}_{2}\left(\mathrm{PO}_{4}\right)_{3}$ phase can be more clearly seen in the selected SXRPD patterns (scan number 40-60) of Figure 2b. The appearance of the $\mathrm{Na}_{2} \mathrm{~V}_{2}\left(\mathrm{PO}_{4}\right)_{3}$ phase indicates that the electrochemical mechanisms of $\mathrm{Na}^{+}$insertion/extraction in $\mathrm{Na}_{3} \mathrm{~V}_{2}\left(\mathrm{PO}_{4}\right)_{3}$, involving the $\mathrm{V}^{4+/ 3+}$ redox couple at $\sim 3.4 \mathrm{~V}$ (vs. $\mathrm{Na}^{+} / \mathrm{Na}$ ), are different from what has been reported before. ${ }^{13,17-}$ 22 
a)
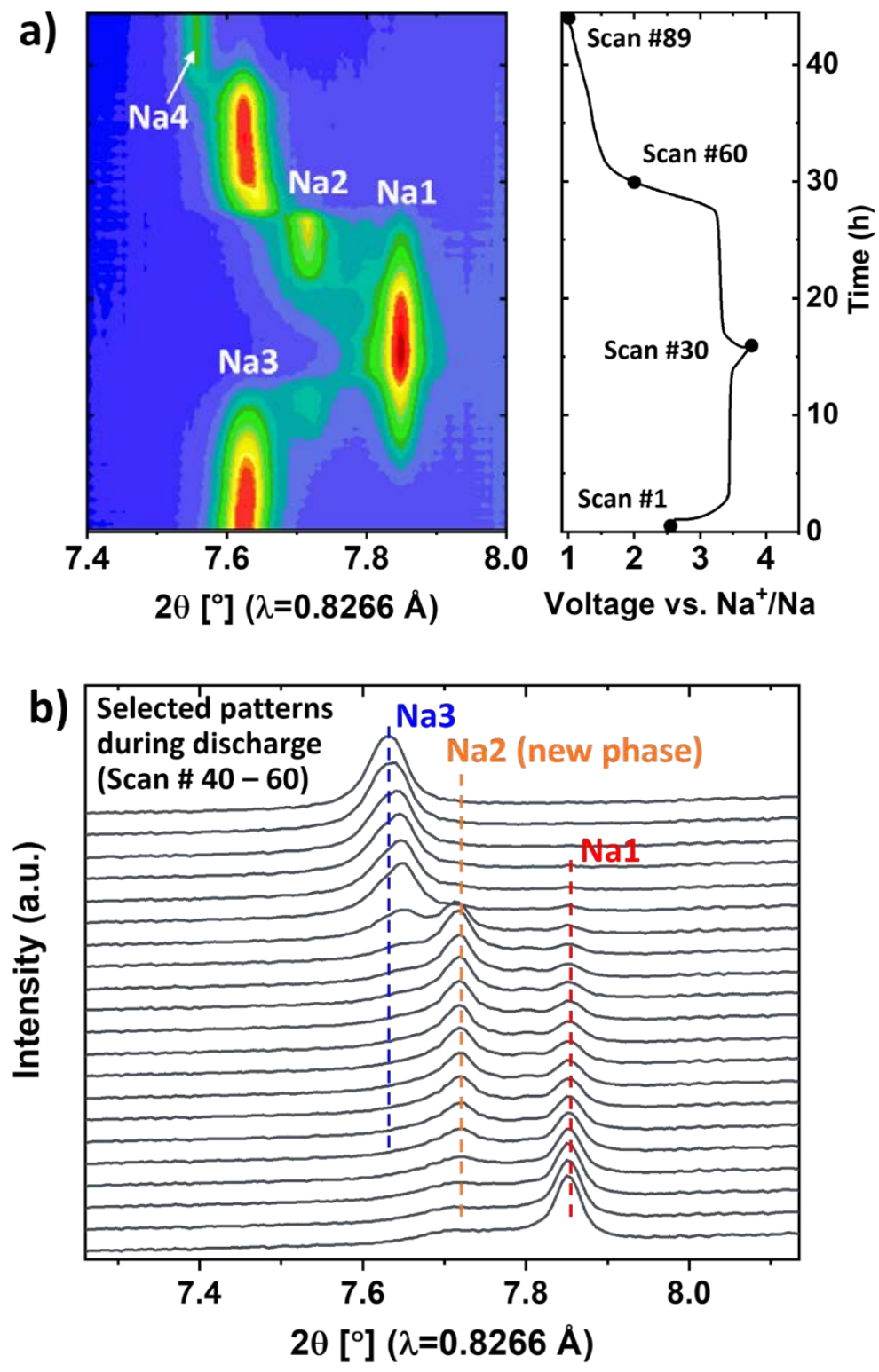

Figure 2. a) Operando SXRPD patterns using $\mathrm{Na}_{3} \mathrm{~V}_{2}\left(\mathrm{PO}_{4}\right)_{3}$ as positive electrode material in a half cell versus $\mathrm{Na}$ metal upon charge and discharge, with a voltage window of $1.0-3.75 \mathrm{~V} \mathrm{vs}$. $\mathrm{Na}^{+} / \mathrm{Na}^{2}$ a a $\mathrm{C}-$ rate of $0.11 \mathrm{C}\left(\approx 1 \mathrm{Na}^{+}\right.$in $\left.9 \mathrm{~h}\right)$. b) Selected SXRPD patterns (from scan number 40-60 during discharge), where the intermediate $\mathrm{Na}_{2} \mathrm{~V}_{2}\left(\mathrm{PO}_{4}\right)_{3}$ phase appears more clearly. $\mathrm{Na}_{x}(\mathrm{x}=1,2$, and 3$)$ refers to $\mathrm{Na}_{x} \mathrm{~V}_{2}\left(\mathrm{PO}_{4}\right)_{3}$.

The intermediate $\mathrm{Na}_{2} \mathrm{~V}_{2}\left(\mathrm{PO}_{4}\right)_{3}$ phase tended to coexist with the $\mathrm{Na}_{3} \mathrm{~V}_{2}\left(\mathrm{PO}_{4}\right)_{3}$ and $\mathrm{Na}_{1} \mathrm{~V}_{2}\left(\mathrm{PO}_{4}\right)_{3}$ phases at low C-rate $(0.11 \mathrm{C})$. However, when a higher current density was applied (i.e., towards a non-equilibrium state), the $\mathrm{Na}_{2} \mathrm{~V}_{2}\left(\mathrm{PO}_{4}\right)_{3}$ phase became more isolated. Similarly, in the operando study of $\mathrm{LiFePO}_{4}$, a higher C-rate $(1 \mathrm{C}$ to $10 \mathrm{C}$ ) allowed a more intense appearance of the intermediate $\mathrm{Li}_{x} \mathrm{FePO}_{4}$ phase. ${ }^{30}$ Even though the C-rates used in this study 
were relatively low, the battery cells already reached a non-equilibrium condition. This is probably because (i) the $\mathrm{Na}_{3} \mathrm{~V}_{2}\left(\mathrm{PO}_{4}\right)_{3}$ powder contains relatively large particles (see Figure S1); and (ii) the electrodes without binder can induce a higher overpotential. ${ }^{45}$ This is further confirmed by the observation of the large polarization of $\sim 150 \mathrm{mV}$ using the in situ cell compared to a low polarization of $30 \mathrm{mV}$ observed using a normal coin cell, cycled at the same C-rate of 0.11 C (Figure S5). Figure S6 shows operando SXRPD data collected during six cycles with the C-rates of $0.37-0.77-0.77-0.77-0.37-0.77 \mathrm{C}$ (which are about three to seven times higher current densities than $0.11 \mathrm{C}$ ). To increase the chance of isolating a 'pure' $\mathrm{Na}_{2} \mathrm{~V}_{2}\left(\mathrm{PO}_{4}\right)_{3}$ phase, multiple cycles were measured. The SXRPD pattern which appears mostly composed by the $\mathrm{Na}_{2} \mathrm{~V}_{2}\left(\mathrm{PO}_{4}\right)_{3}$ phase was obtained during the last cycle (see Figure S6 for more details).

Figure 3 shows a comparison of the SXRPD patterns among the $\mathrm{Na}_{x} \mathrm{~V}_{2}\left(\mathrm{PO}_{4}\right)_{3}(x=1,2$, and 3$)$ compositions. Importantly, a careful evaluation of the SXRPD pattern of $\mathrm{Na}_{2} \mathrm{~V}_{2}\left(\mathrm{PO}_{4}\right)_{3}$ reveals the appearance of weak Bragg peak at a very low $2 \theta$ angle $\left(\sim 3.85^{\circ}, d_{h k l}=12.29 \AA\right)$. With operando technic, this weak Bragg peak at such a low angle (equivalent to $7.2^{\circ}$ in $\mathrm{Cu}_{\mathrm{K} \alpha}$ radiation) may be missed with a standard laboratory X-ray equipment, while we clearly observed it with a synchrotron X-ray source. This provides critical information to solve the crystal structure of $\mathrm{Na}_{2} \mathrm{~V}_{2}\left(\mathrm{PO}_{4}\right)_{3}$. 

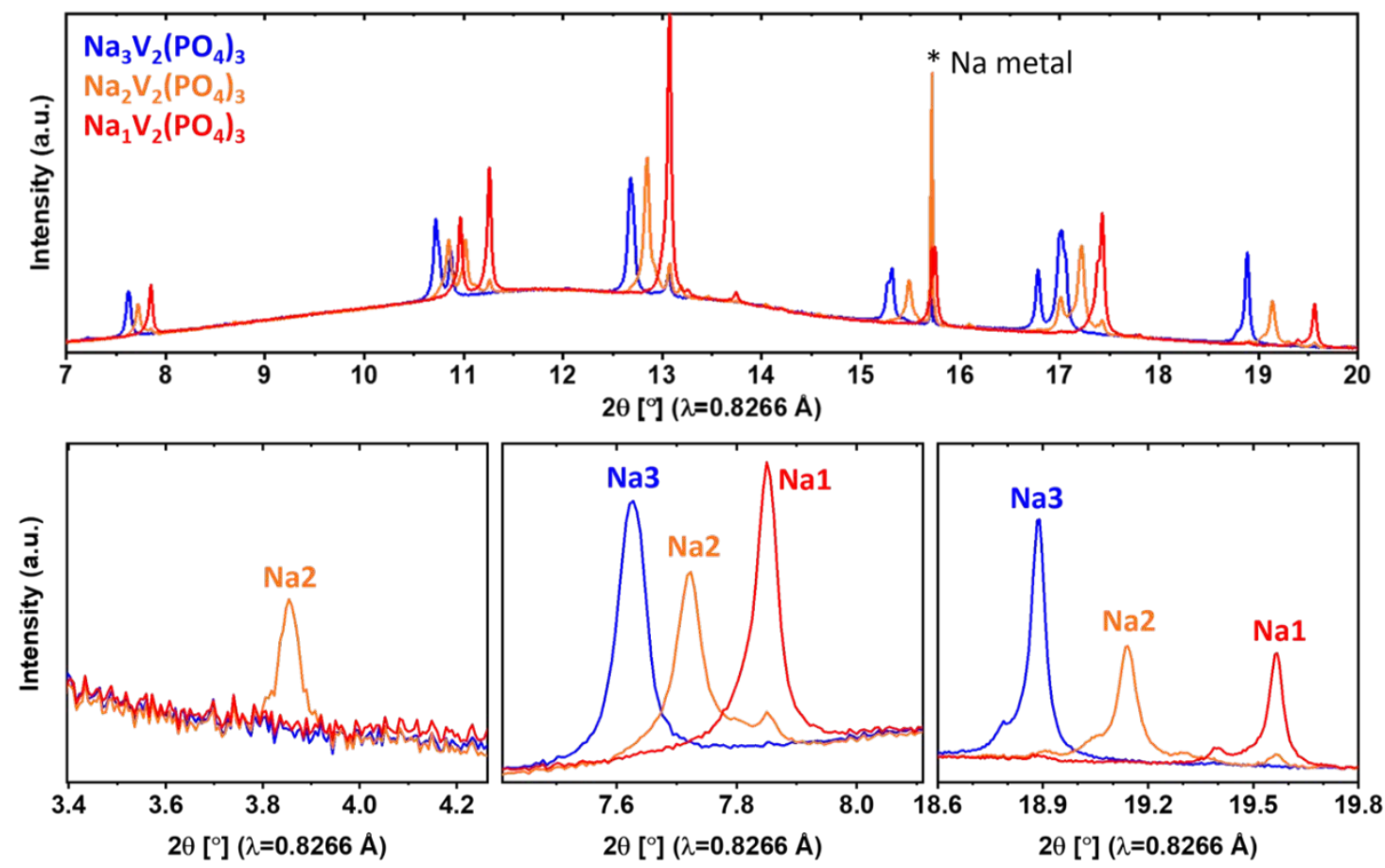

Figure 3. The SXRPD patterns of $\mathrm{Na}_{3} \mathrm{~V}_{2}\left(\mathrm{PO}_{4}\right)_{3}$ (blue), $\mathrm{Na}_{2} \mathrm{~V}_{2}\left(\mathrm{PO}_{4}\right)_{3}$ (orange), and $\mathrm{Na}_{1} \mathrm{~V}_{2}\left(\mathrm{PO}_{4}\right)_{3}$ (red) with different angular domains. The Bragg peak at $3.85^{\circ}$ is only observed for the new $\mathrm{Na}_{2} \mathrm{~V}_{2}\left(\mathrm{PO}_{4}\right)_{3}$ phase. The overall positions of the Bragg peaks manifest the appearance of the intermediate phase which can be differentiated from $\mathrm{Na}_{3} \mathrm{~V}_{2}\left(\mathrm{PO}_{4}\right)_{3}$ and $\mathrm{Na}_{1} \mathrm{~V}_{2}\left(\mathrm{PO}_{4}\right)_{3}$ phases.

The powder pattern of $\mathrm{Na}_{2} \mathrm{~V}_{2}\left(\mathrm{PO}_{4}\right)_{3}$ presented in Figure $\mathbf{3}$ was then used to solve its crystal structure. The indexing of the powder pattern, the space group determination, and the cell transformation with group-subgroup relationships were carried out using Dicvol, ${ }^{46}$ Chekcell, $^{47}$ and POWDERCELL ${ }^{48}$ software, to fully resolve the crystal structure of $\mathrm{Na}_{2} \mathrm{~V}_{2}\left(\mathrm{PO}_{4}\right)_{3}$. During the steps of indexing and space group determination, it was found that the reflection at $2 \theta=3.85^{\circ}$ excludes the rhombohedral lattices (Figure S7) as well as Ccentered monoclinic-type cells (Figure S8). Possible space groups are then primitive, and thus several structure models with different space groups were examined to solve the structure. The initial atomic positions of each model were deduced from the groupsubgroup relationships starting from the $R 3 c$ rhombohedral cell. The highest to lowest symmetry of the examined space groups are $P 2_{1} / c, P 2 / c, P 2_{1} / \mathrm{m}$, and $P / \mathrm{m}$ (corresponding to $22,23,42$, and 46 independent atoms per cell, respectively). We attempted unsuccessfully to solve the structure using the two space groups $\left(P 2_{1} / \mathrm{m}\right.$, and $\left.P / \mathrm{m}\right)$. The structure model, namely "Model 1 ", using the $P 2_{1} / c$ space group showed slightly better results than that 
using a $P 2 / c$ space group (i.e., Model 2). The detailed comparisons between Models 1 and 2 are discussed later in this paper.

For the structure of $\mathrm{Na}_{2} \mathrm{~V}_{2}\left(\mathrm{PO}_{4}\right)_{3}$ using the space group $P 2_{1} / c$ (Model 1 ), the refined cell parameters are: $a=15.2377(5) \AA, b=8.6082(5) \AA, c=8.7391(4) \AA, b=126.281(3), V / Z=$ 231.02(2) $\AA^{3}$. The results of Rietveld refinement are presented in Figure 4a, illustrating that the reflection at $2 \theta=3.85^{\circ}$ can be fully explained. The final refinement was performed using $\mathrm{Na}_{3} \mathrm{~V}_{2}\left(\mathrm{PO}_{4}\right)_{3}$ and $\mathrm{Na}_{1} \mathrm{~V}_{2}\left(\mathrm{PO}_{4}\right)_{3}$ as secondary phases with final weight fractions of $8.4(5)$ and 7.1(3) \%, respectively. The global structural information, including atomic coordinates, atomic displacement parameters, and occupancy factors, are listed in Table 1. The crystal structure of $\mathrm{Na}_{2} \mathrm{~V}_{2}\left(\mathrm{PO}_{4}\right)_{3}$ contains two different vanadium Wyckoff positions, $\mathrm{V}(1 \mathrm{a})$ and $\mathrm{V}(1 \mathrm{~b})$, involved in the same lantern unit as illustrated in Figure $\mathbf{4 b}$. From the examination of the V-O bond distances (Table S2), it appears that the environment of both $V(1 a)$ and $V(1 b)$ are similar with an average $\mathrm{V}$-O bond distance of $1.99(9) \AA$, which suggests that $\mathrm{V}^{3+}$ and $\mathrm{V}^{4+}$ are randomly distributed over the $\mathrm{V}(1 \mathrm{a})$ and $\mathrm{V}(1 \mathrm{~b})$ positions. For the Na crystallographic sites, the $\mathrm{Na}(1)$ and $\mathrm{Na}(2)$ sites split into two $\mathrm{Na}(1)$ (labeled $\mathrm{Na}(1 \mathrm{a})$ and $\mathrm{Na}(1 \mathrm{~b})$ ) and three $\mathrm{Na}(2)$ positions (labeled $\mathrm{Na}\left(2 \mathrm{a}_{1}\right), \mathrm{Na}\left(2 \mathrm{a}_{2}\right)$, and $\mathrm{Na}(2 \mathrm{~b})$ ) in the space group $\mathrm{P} 2_{1} / \mathrm{c}$. The refined occupancy factor for $\mathrm{Na}\left(2 \mathrm{a}_{2}\right)$ position was $0.08(7)$, which can be considered as fully empty. The refined occupancy factors for $\mathrm{Na}(1 \mathrm{a}), \mathrm{Na}(1 \mathrm{~b}), \mathrm{Na}\left(2 \mathrm{a}_{1}\right)$, and $\mathrm{Na}(2 \mathrm{~b})$ are 1, 0.98(8), 0.36(7), and $0.73(10)$, respectively, yielding a composition $\mathrm{Na}_{2.1(3)} \mathrm{V}_{2}\left(\mathrm{PO}_{4}\right)_{3}$. 

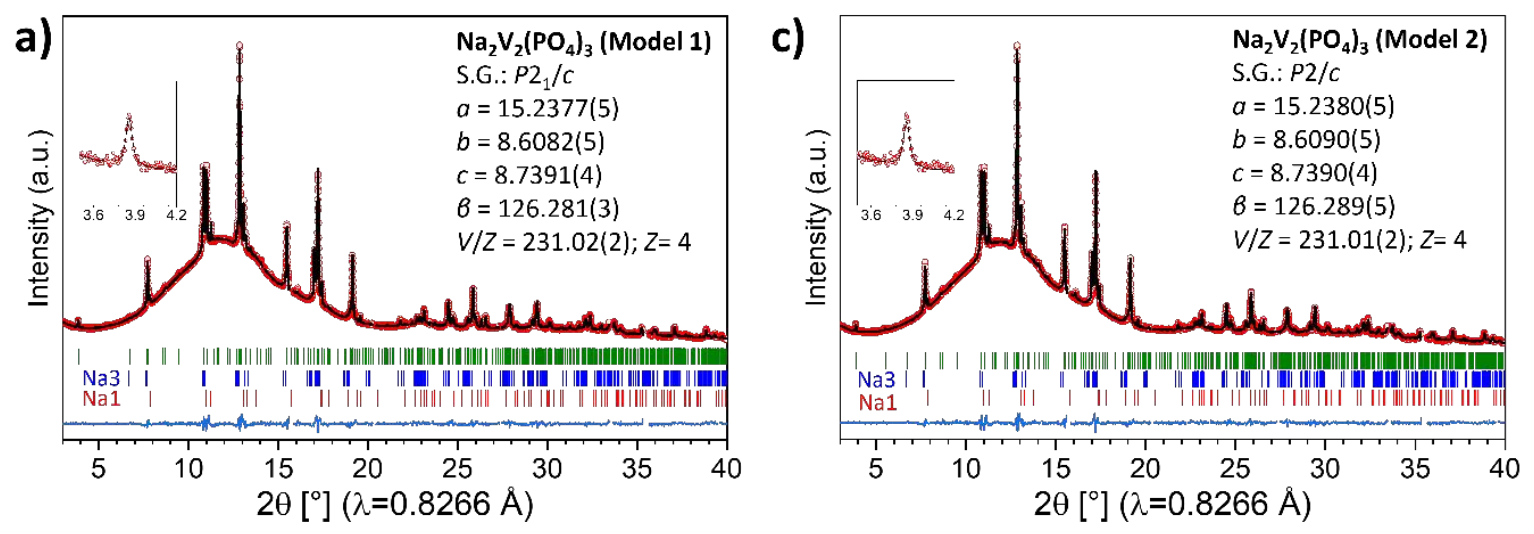

b)

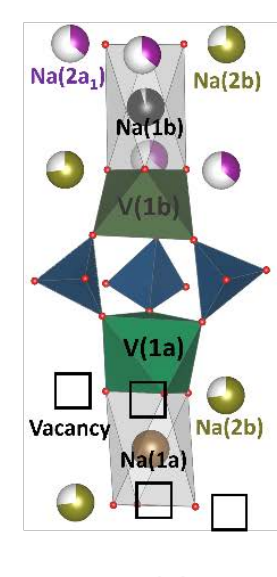

d)
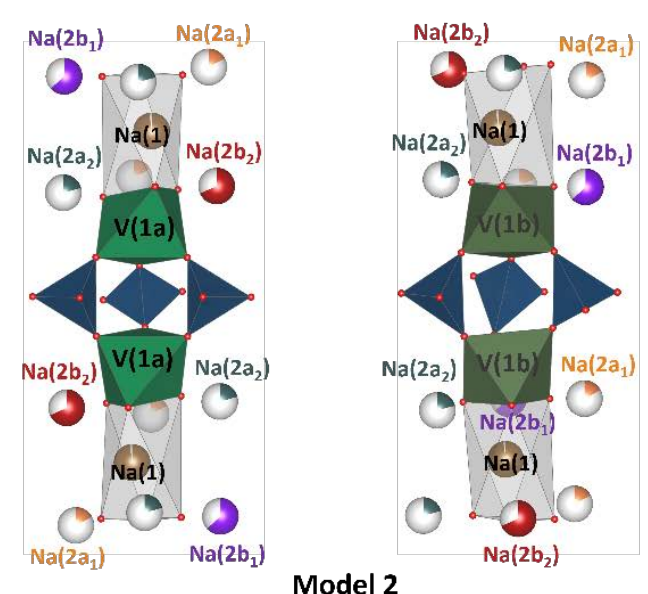

Figure 4. Rietveld refinement results of the intermediate phase $\mathrm{Na}_{2} \mathrm{~V}_{2}\left(\mathrm{PO}_{4}\right)_{3}$ using a) the space group $P 2_{1} / c$ (Model 1) and b) the space group $P 2 / c$ (Model 2). c) Lantern unit with adjacent $\mathrm{Na}^{+}$ions in the crystal structure of $\mathrm{Na}_{2} \mathrm{~V}_{2}\left(\mathrm{PO}_{4}\right)_{3}$, refined with the space group $P 2_{1} / c$. $V(1 \mathrm{a})$ and $V(1 \mathrm{~b})$ atoms are involved in a single lantern unit. Vacant $\mathrm{Na}^{+}$positions are shown as empty squares. $d$ ) Lantern units with adjacent $\mathrm{Na}^{+}$ions in the crystal structure of $\mathrm{Na}_{2} \mathrm{~V}_{2}\left(\mathrm{PO}_{4}\right)_{3}$, refined with the space group $\mathrm{P} 2 / \mathrm{C}$. Two different lantern units exist in the structure: each vanadium position forms a distinct lantern unit.

We tested another structural model for $\mathrm{Na}_{2} \mathrm{~V}_{2}\left(\mathrm{PO}_{4}\right)_{3}$ using the space group $P 2 / c$ (Model 2), which showed similar agreement factors with the following cell parameters: $a=15.2380(5)$ $\AA ; b=8.6090(5) \AA ; ; c=8.7390(4) ; b=126.289(5), V / Z=231.01(2) \AA^{3}$ (Figure 4c). Model 2 also contains two vanadium positions, but it generates two distinct lantern units in the structure: one with two $V(1 a)$ atoms and the other one with two $V(1 b)$ atoms (Figure $4 d$ ). Furthermore, the average $\mathrm{V}-\mathrm{O}$ distances in $\mathrm{V}(1 \mathrm{a}) \mathrm{O}_{6}$ and $\mathrm{V}(1 \mathrm{~b}) \mathrm{O}_{6}$ octahedra are 1.92(8) $\AA$ and 2.04(8) $\AA$, respectively, suggesting a possible charge ordering of the $\mathrm{V}^{4+}$ and $\mathrm{V}^{3+}$ in the crystal structure (see the details of V-O distances in Table S2). In terms of V charge ordering, Model 2 compares well with the DFT data discussed below. Finally, the $\mathrm{Na}(1)$ site is unique, while the $\mathrm{Na}(2)$ site splits into four distinct Wyckoff positions, i.e., $\mathrm{Na}\left(2 \mathrm{a}_{1}\right), \mathrm{Na}\left(2 \mathrm{a}_{2}\right), \mathrm{Na}\left(2 \mathrm{~b}_{1}\right)$, and 
$\mathrm{Na}\left(2 \mathrm{~b}_{2}\right)$. The refined occupancy factors for $\mathrm{Na}(1), \mathrm{Na}\left(2 \mathrm{a}_{1}\right), \mathrm{Na}\left(2 \mathrm{a}_{2}\right), \mathrm{Na}\left(2 \mathrm{~b}_{1}\right)$, and $\mathrm{Na}\left(2 \mathrm{~b}_{2}\right)$ are $0.98(3), 0.17(7), 0.21(7), 0.63(11)$, and $0.68(11)$, respectively, yielding a composition $\mathrm{Na}_{2.0(3)} \mathrm{V}_{2}\left(\mathrm{PO}_{4}\right)_{3}$. Detailed structural information is listed in Table S3.

Table 1. Refined structural parameters of the intermediate phase $\mathrm{Na}_{2} \mathrm{~V}_{2}\left(\mathrm{PO}_{4}\right)_{3}$ using the space group $P 2_{1} / c$ (Model 1). ${ }^{a}$ Refined and fixed at the last stages of refinement.

\begin{tabular}{|c|c|c|c|c|c|c|}
\hline \multicolumn{7}{|c|}{$\begin{array}{c}\mathrm{Na}_{2} \mathbf{V}_{\mathbf{2}}\left(\mathrm{PO}_{4}\right)_{3} \\
\text { Space group: } P 2_{1} / c(\# 14) ; Z=4 \\
\mathrm{a}=15.2377(5) \AA ; \quad b=8.6082(5) \AA ; c=8.7391(4) ; b=126.281(3) ; \\
\mathrm{V}=924.069(8) \AA^{3} ; \mathrm{V} / Z=231.02(2) \AA^{3} \\
R_{\mathrm{wp}}=13.3 \% ; R_{\mathrm{p}}=19.5 \% ; R_{\text {bragg }}=6.21 \%\end{array}$} \\
\hline Atom & $\begin{array}{l}\text { Wyckoff } \\
\text { position }\end{array}$ & $x / a$ & $y / b$ & $z / c$ & Uiso, $\AA^{2}$ & Occ. \\
\hline$V(1 a)$ & $4 e$ & $0.848(2)$ & $0.492(5)$ & $0.630(4)$ & $0.026(3)$ & 1 \\
\hline$V(1 b)$ & $4 e$ & $0.640(2)$ & $0.493(5)$ & $0.834(4)$ & $0.026(3)$ & 1 \\
\hline$P(1 a)$ & $4 e$ & $0.1047(10)$ & $0.3521(17)$ & $0.958(2)$ & $0.033(4)$ & 1 \\
\hline$P(1 b)$ & $4 e$ & $0.3965(10)$ & $0.3581(17)$ & $0.564(2)$ & $0.033(4)$ & 1 \\
\hline$P(2)$ & $4 e$ & $0.2572(10)$ & $0.7725(14)$ & $0.262(2)$ & $0.033(4)$ & 1 \\
\hline $\mathrm{O}(1 \mathrm{~b})$ & $4 e$ & $0.397(7)$ & $0.372(10)$ & $0.389(7)$ & $0.012(3)$ & 1 \\
\hline$O(1 d)$ & $4 e$ & $0.094(7)$ & $0.423(7)$ & $0.107(10)$ & $0.012(3)$ & 1 \\
\hline $\mathrm{O}(1 \mathrm{e})$ & $4 e$ & $0.338(5)$ & $0.700(10)$ & $0.230(10)$ & $0.012(3)$ & 1 \\
\hline $\mathrm{O}(2 \mathrm{~b})$ & $4 e$ & $0.208(6)$ & $0.637(5)$ & $0.303(10)$ & $0.012(3)$ & 1 \\
\hline $\mathrm{O}(2 \mathrm{c})$ & $4 e$ & $0.706(5)$ & $0.916(10)$ & $0.960(14)$ & $0.012(3)$ & 1 \\
\hline$O(2 f)$ & $4 e$ & $0.805(5)$ & $0.926(10)$ & $0.547(14)$ & $0.012(3)$ & 1 \\
\hline $\mathrm{O}(1 \mathrm{a})$ & $4 e$ & $0.398(7)$ & $0.319(2)$ & $0.081(14)$ & $0.012(3)$ & 1 \\
\hline $\mathrm{O}(1 \mathrm{c})$ & $4 e$ & $0.104(7)$ & $0.325(2)$ & $0.478(10)$ & $0.012(3)$ & 1 \\
\hline$O(1 f)$ & $4 e$ & $0.004(5)$ & $0.085(10)$ & $0.270(7)$ & $0.012(3)$ & 1 \\
\hline $\mathrm{O}(2 \mathrm{a})$ & $4 e$ & $0.506(5)$ & $0.083(10)$ & $0.240(7)$ & $0.012(3)$ & 1 \\
\hline$O(2 d)$ & $4 e$ & $0.331(7)$ & $0.614(10)$ & $0.927(10)$ & $0.012(3)$ & 1 \\
\hline $\mathrm{O}(2 \mathrm{e})$ & $4 e$ & $0.167(6)$ & $0.639(10)$ & $0.582(7)$ & $0.012(3)$ & 1 \\
\hline $\mathrm{Na}(1 \mathrm{a})$ & $2 a$ & 0 & 0 & 0 & $0.090(13)$ & $1^{\mathrm{a}}$ \\
\hline $\mathrm{Na}(1 \mathrm{~b})$ & $2 d$ & 0.5 & 0 & 0.5 & $0.090(13)$ & $0.98(8)$ \\
\hline $\mathrm{Na}\left(2 \mathrm{a}_{1}\right)$ & $4 e$ & $0.557^{a}$ & $0.168^{a}$ & $0.908^{a}$ & $0.090(13)$ & $0.36(7)$ \\
\hline $\mathrm{Na}\left(2 \mathrm{a}_{2}\right)$ & $4 e$ & 0.936 & 0.169 & 0.565 & $0.090(13)$ & $0^{\mathrm{a}}$ \\
\hline $\mathrm{Na}(2 \mathrm{~b})$ & $4 e$ & $0.232(7)$ & $0.140(14)$ & $0.243(14)$ & $0.090(13)$ & $0.73(10)$ \\
\hline
\end{tabular}


Note that both monoclinic structural models for $\mathrm{Na}_{2} \mathrm{~V}_{2}\left(\mathrm{PO}_{4}\right)_{3}\left(P 2 / c\right.$ and $\left.P 2_{1} / c\right)$ have very similar cell parameters and can fully account for the existence of the (100) reflection at $2 \theta=$ $3.85^{\circ}$. However, subtle differences to distinguish between the two space groups are convoluted in the possible existence of [(0k0), $k=2 n+1]$ reflections for $P 2 / c$ while they are forbidden for $P 2_{1} / c$. A very low-intensity peak at $\sim 5.5^{\circ}$ (of the SXRPD pattern) could be assigned to the (010) reflection in the space group $P 2 / C$, although the same was also observed in $\mathrm{Na}_{3} \mathrm{~V}_{2}\left(\mathrm{PO}_{4}\right)_{3}$ and $\mathrm{Na}_{1} \mathrm{~V}_{2}\left(\mathrm{PO}_{4}\right)_{3}$ phases with the same intensity. This evidence suggests this peak may not originate from the phase reflection of $\mathrm{Na}_{x} \mathrm{~V}_{2}\left(\mathrm{PO}_{4}\right)_{3}$ but it is rather a noisy background (Figure S9). For this reason, we believe that the $P 2_{1} / c$ model (Model 1 ) is more suitable, although the $P 2 / c$ one (Model 2 ) cannot be completely excluded.

To shed light on the thermodynamic stability of the intermediate $\mathrm{Na}_{2} \mathrm{~V}_{2}\left(\mathrm{PO}_{4}\right)_{3}$ phase, detected with our SXRPD diffraction, we performed dedicated DFT calculations. Figure $\mathbf{5}$ shows the thermodynamic properties of $\mathrm{Na}_{x} \mathrm{~V}_{2}\left(\mathrm{PO}_{4}\right)_{3}$ in the region of $\mathrm{x}=1-3$ at $0 \mathrm{~K}$, as computed by DFT. Figure 5a shows the DFT mixing enthalpies ( $H_{\text {mixing }}$ in eq. 2 ) for all $\mathrm{Na}$ /vacancy orderings of the $\mathrm{Na}_{x} \mathrm{~V}_{2}\left(\mathrm{PO}_{4}\right)_{3}$ compositions. Using a convex hull minimization algorithm, all the ground-state configurations were obtained. It can be concluded that besides the endmembers $\mathrm{Na}_{1} \mathrm{~V}_{2}\left(\mathrm{PO}_{4}\right)_{3}$ and $\mathrm{Na}_{3} \mathrm{~V}_{2}\left(\mathrm{PO}_{4}\right)_{3}$, which are assigned to rhombohedral and monoclinic symmetry, respectively, a new phase $\mathrm{Na}_{2} \mathrm{~V}_{2}\left(\mathrm{PO}_{4}\right)_{3}$ appears as a stable configuration. However, $\mathrm{Na}_{2} \mathrm{~V}_{2}\left(\mathrm{PO}_{4}\right)_{3}$ shows a relatively low mixing enthalpy (ca. -23 meV/f.u.) with respect to $\mathrm{Na}_{1} \mathrm{~V}_{2}\left(\mathrm{PO}_{4}\right)_{3}$ and $\mathrm{Na}_{3} \mathrm{~V}_{2}\left(\mathrm{PO}_{4}\right)_{3}$, and this suggests that the intermediate phase may be metastable at room temperature.

Table 2. Unit cell parameters, $\mathrm{Na}$ occupancy factors, and average of $\mathrm{V}-\mathrm{O}$ distances of $\mathrm{Na}_{2} \mathrm{~V}_{2}\left(\mathrm{PO}_{4}\right)_{3}$ obtained by DFT calculations.

\begin{tabular}{|c|c|c|c|c|c|c|c|c|c|c|c|c|}
\hline & S.G. & $a$ & $b$ & $c$ & $\alpha$ & $\beta$ & $v$ & $v / Z$ & $\begin{array}{c}\mathrm{Na}(1) \\
\text { /f.u. }\end{array}$ & $\begin{array}{c}\mathrm{Na}(2) \\
\text { /f.u. }\end{array}$ & $\begin{array}{c}\text { Total } \\
\text { Na /f.u. }\end{array}$ & $\begin{array}{l}\text { Avg. } \\
\text { V-O (Å) }\end{array}$ \\
\hline $\mathrm{Na}_{2} \mathrm{~V}_{2}\left(\mathrm{PO}_{4}\right)_{3}$ & $P 1$ & 8.712 & 8.667 & 8.629 & 59.729 & 58.858 & 59.602 & 227.159 & 1 & 1 & 2 & 1.964 \\
\hline
\end{tabular}

Table 2 presents unit cell parameters, sodium occupancy factors, and the average of $\mathrm{V}-\mathrm{O}$ distances of the $\mathrm{Na}_{2} \mathrm{~V}_{2}\left(\mathrm{PO}_{4}\right)_{3}$ structure obtained by DFT calculations. The computed 
structure of $\mathrm{Na}_{2} \mathrm{~V}_{2}\left(\mathrm{PO}_{4}\right)_{3}$ shows a similar cell volume with the experimentally observed one, and this calculated phase is assigned to a triclinic symmetry $P 1$ with distinguished $V^{4+}$ and $\mathrm{V}^{3+}$ states, and with fully ordered $\mathrm{Na}(1)$ and $\mathrm{Na}(2)$ sites. Higher temperatures will enable other Na-vacancy ordering to be stable, with intrinsic symmetries maybe similar to what was found experimentally. Therefore, the structures extracted from the synchrotron measurements can be assumed with a superposition of several Na-vacancy orderings. A closer look to the local arrangement of $\mathrm{Na}$ ions in the DFT structure of $\mathrm{Na}_{2} \mathrm{~V}_{2}\left(\mathrm{PO}_{4}\right)_{3}$ shows that fully occupied $\mathrm{Na}(1)$ site is surrounded by two fully occupied $\mathrm{Na}(2)$ sites and four vacancies. ${ }^{49}$ Consequently, we could observe unique $\mathrm{Na}^{+}$sites of the $\mathrm{Na}_{2} \mathrm{~V}_{2}\left(\mathrm{PO}_{4}\right)_{3}$ groundstate predicted by DFT split into a larger number of distinct Wyckoff positions compared to what elaborated by our experimental Model 1 and 2. However, our room-temperature synchrotron data of the intermediate $\mathrm{Na}_{2} \mathrm{~V}_{2}\left(\mathrm{PO}_{4}\right)_{3}$ structure detected under non-equilibrium conditions will likely incorporate several possible Na-vacancy configurations, averaging out the $\mathrm{Na}$ ions among the available $\mathrm{Na}(1)$ and $\mathrm{Na}(2)$ sites, which can be the origin of the observed fractional occupancies from SXRPD. ${ }^{44,50}$ Furthermore, our DFT calculations suggest a specific vanadium charge orderings within the ground-state $\mathrm{Na}_{2} \mathrm{~V}_{2}\left(\mathrm{PO}_{4}\right)_{3}$, which may be disrupted by temperature effects. Ongoing synthesis efforts to obtain $\mathrm{Na}_{2} \mathrm{~V}_{2}\left(\mathrm{PO}_{4}\right)_{3}$ chemically as a pure phase will further clarify the discrepancies between the DFT data and our experimental models.

Figure $\mathbf{5 b}$ depicts the DFT-derived voltage profile in the region of $\mathrm{Na}_{1} \mathrm{~V}_{2}\left(\mathrm{PO}_{4}\right)_{3}$ to $\mathrm{Na}_{3} \mathrm{~V}_{2}\left(\mathrm{PO}_{4}\right)_{3}$. By identifying the $\mathrm{Na}_{2} \mathrm{~V}_{2}\left(\mathrm{PO}_{4}\right)_{3}$ phase, we could realize two voltage plateaus while $\mathrm{Na}^{+}$ intercalation via biphasic reaction mechanisms, namely $3.29 \mathrm{~V}$ vs. $\mathrm{Na}^{+} / \mathrm{Na}$ between $\mathrm{Na}_{1} \mathrm{~V}_{2}\left(\mathrm{PO}_{4}\right)_{3}$ and $\mathrm{Na}_{2} \mathrm{~V}_{2}\left(\mathrm{PO}_{4}\right)_{3}$, and $3.24 \mathrm{~V}$ vs. $\mathrm{Na}^{+} / \mathrm{Na}$ between $\mathrm{Na}_{2} \mathrm{~V}_{2}\left(\mathrm{PO}_{4}\right)_{3}$ and $\mathrm{Na}_{3} \mathrm{~V}_{2}\left(\mathrm{PO}_{4}\right)_{3}$. Notably, the $\mathrm{Na}$ ordering of $\mathrm{Na}_{2} \mathrm{~V}_{2}\left(\mathrm{PO}_{4}\right)_{3}$ give rise to a small voltage step ( $\sim 50 \mathrm{mV}$ ). 

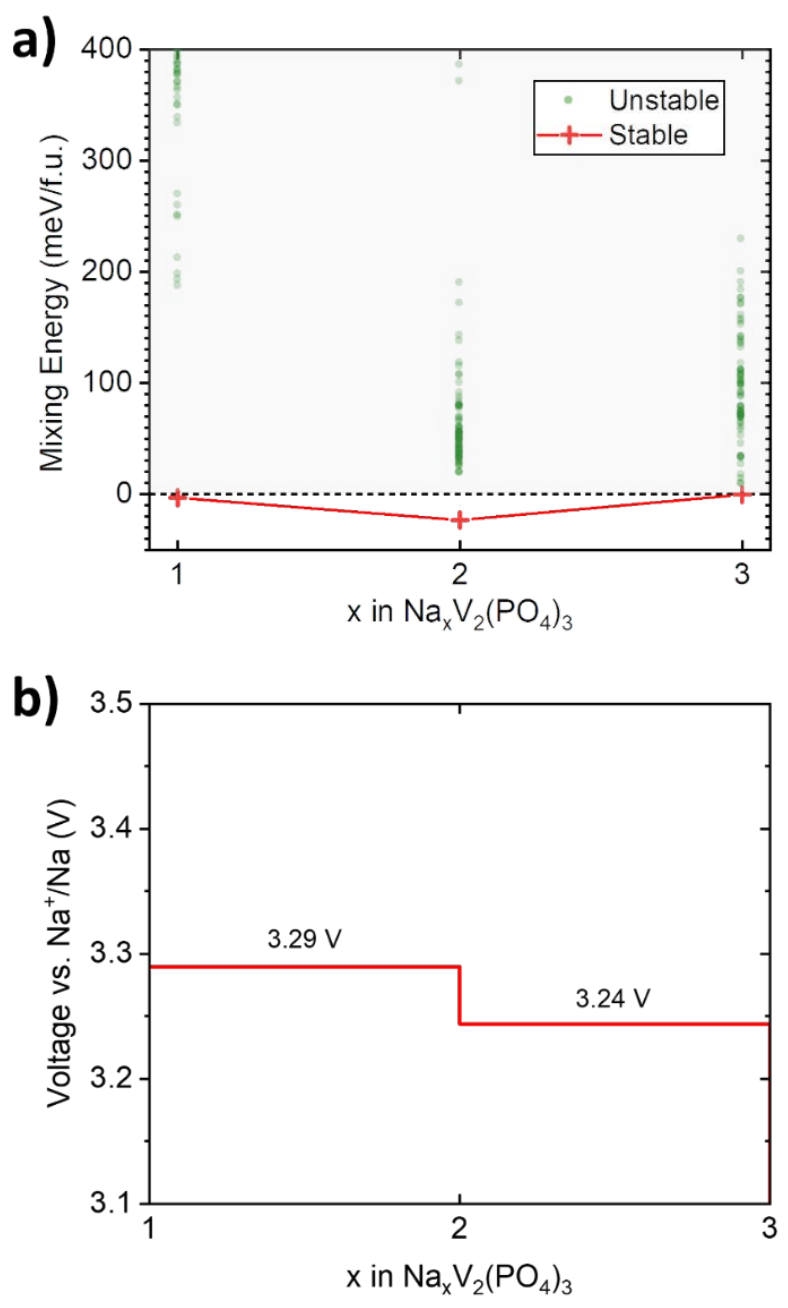

Figure 5. a) DFT-derived phase diagram in the composition range $(1 \leq x \leq 3)$ for $\mathrm{Na}_{x} \mathrm{~V}_{2}\left(\mathrm{PO}_{4}\right)_{3}$ at $0 \mathrm{~K}$, in terms of $\mathrm{Na}$ mixing enthalpies. The stable ground-state configurations, namely $\mathrm{Na}_{1} \mathrm{~V}_{2}\left(\mathrm{PO}_{4}\right)_{3}$, $\mathrm{Na}_{1} \mathrm{~V}_{2}\left(\mathrm{PO}_{4}\right)_{3}$ and $\mathrm{Na}_{3} \mathrm{~V}_{2}\left(\mathrm{PO}_{4}\right)_{3}$, and the unstable configurations are represented by red cross and green dots, respectively. b) The computed voltage profile from $\mathrm{Na}_{1} \mathrm{~V}_{2}\left(\mathrm{PO}_{4}\right)_{3}$ to $\mathrm{Na}_{3} \mathrm{~V}_{2}\left(\mathrm{PO}_{4}\right)_{3}$.

Having the crystal structures of the new $\mathrm{Na}_{2} \mathrm{~V}_{2}\left(\mathrm{PO}_{4}\right)_{3}$ phase determined (with the space group $P 2_{1} / c$ ), the operando SXRPD data (shown in Figure 2 ) were analyzed by Rietveld refinements including the evolutions of phase transitions, cell volumes, and phase weights as shown in Figure 6. Five different regions can be distinguished during the charge and discharge processes (labeled from I to V) in Figure 6. In region I (solid solution part), only $\mathrm{Na}_{3-\delta} \mathrm{V}_{2}\left(\mathrm{PO}_{4}\right)_{3}$ is present and its unit cell volume $(\mathrm{V} / \mathrm{Z})$ slightly decreases from $239.687(6) \AA^{3}$ to $239.384(8) \AA^{3}$. Region II (plateau at $3.4 \mathrm{~V}$ vs. $\mathrm{Na}^{+} / \mathrm{Na}$ ) can be divided into two sub-regions (II' and II"). The $\mathrm{Na}^{+}$extraction mechanism occurs first through an out-of-equilibrium "threephase" reaction, where the amount of $\mathrm{Na}_{3} \mathrm{~V}_{2}\left(\mathrm{PO}_{4}\right)_{3}$ phase decreases while those of 
$\mathrm{Na}_{1} \mathrm{~V}_{2}\left(\mathrm{PO}_{4}\right)_{3}$ and $\mathrm{Na}_{2} \mathrm{~V}_{2}\left(\mathrm{PO}_{4}\right)_{3}$ phases increase concomitantly up to mid-charge (region $\mathrm{II}^{\prime}$ ). This can be rationalized as the overlap of two biphasic reactions of $\mathrm{Na}_{3} \mathrm{~V}_{2}\left(\mathrm{PO}_{4}\right)_{3}-$ $\mathrm{Na}_{2} \mathrm{~V}_{2}\left(\mathrm{PO}_{4}\right)_{3}$ and $\mathrm{Na}_{2} \mathrm{~V}_{2}\left(\mathrm{PO}_{4}\right)_{3}-\mathrm{Na}_{1} \mathrm{~V}_{2}\left(\mathrm{PO}_{4}\right)_{3}$. We note that the two reactions tend to separate more when higher current densities are furnished (Figure S6). After that (in region II" of Figure 6), the quantities of $\mathrm{Na}_{2} \mathrm{~V}_{2}\left(\mathrm{PO}_{4}\right)_{3}$ and $\mathrm{Na}_{3} \mathrm{~V}_{2}\left(\mathrm{PO}_{4}\right)_{3}$ phases diminish, while the $\mathrm{Na}_{1} \mathrm{~V}_{2}\left(\mathrm{PO}_{4}\right)_{3}$ content keeps increasing until the end of charge at $\sim 3.75 \mathrm{~V}$ vs. $\mathrm{Na}^{+} / \mathrm{Na}$. The discharge process down to $\sim 2 \mathrm{~V}$ vs. $\mathrm{Na}^{+} / \mathrm{Na}$ appears rather different (region III). On the plateau, the main reaction seems to occur between $\mathrm{Na}_{1} \mathrm{~V}_{2}\left(\mathrm{PO}_{4}\right)_{3}$ and $\mathrm{Na}_{2} \mathrm{~V}_{2}\left(\mathrm{PO}_{4}\right)_{3}$ via a twophase reaction. At this stage, the amount of $\mathrm{Na}_{3} \mathrm{~V}_{2}\left(\mathrm{PO}_{4}\right)_{3}$ remains low (< $10 \mathrm{wt} \%$ ). Afterwards, in region IV, the phase transition from $\mathrm{Na}_{2} \mathrm{~V}_{2}\left(\mathrm{PO}_{4}\right)_{3}$ to $\mathrm{Na}_{3} \mathrm{~V}_{2}\left(\mathrm{PO}_{4}\right)_{3}$ occurred rapidly. Finally, in region $\mathrm{V}$ (reduction down to $1 \mathrm{~V}$ vs. $\mathrm{Na}^{+} / \mathrm{Na}$ ), a biphasic reaction between $\mathrm{Na}_{3} \mathrm{~V}_{2}\left(\mathrm{PO}_{4}\right)_{3}$ and $\mathrm{Na}_{4} \mathrm{~V}_{2}\left(\mathrm{PO}_{4}\right)_{3}$ is observed.

a)

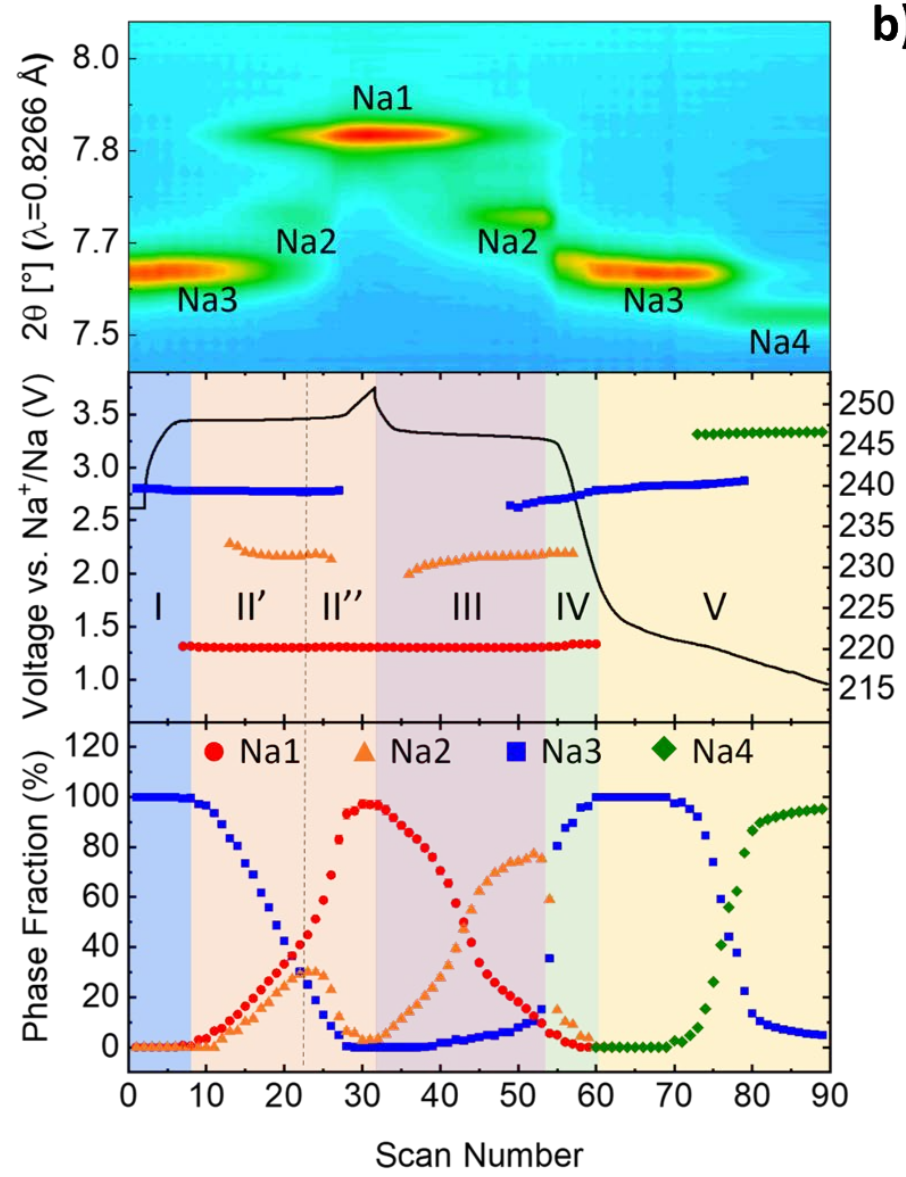

b)

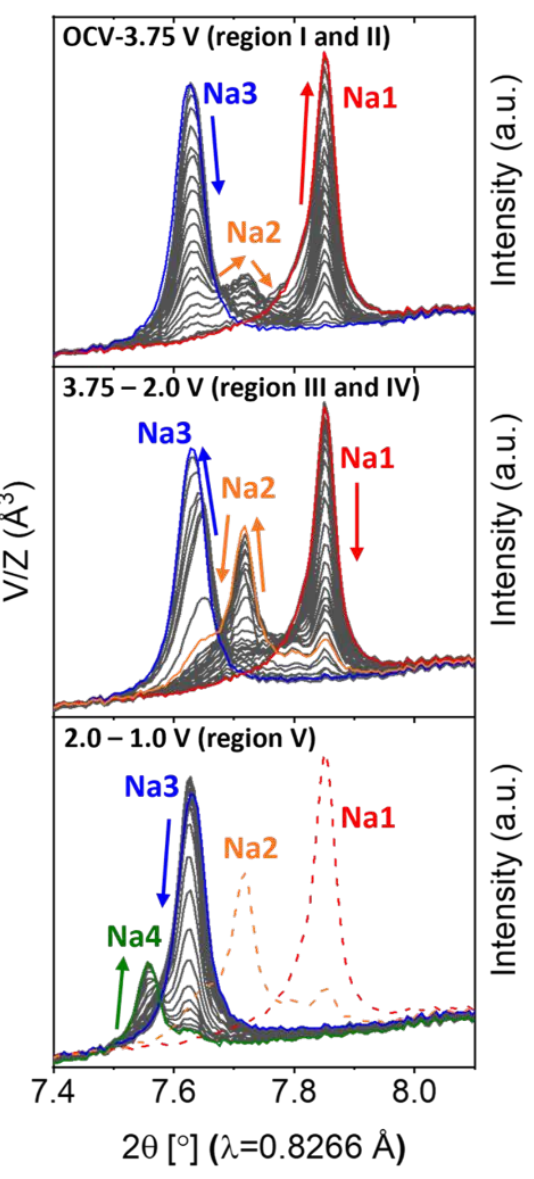

Figure 6. a) Counter plot of operando SXRPD patterns in the 7.46-8.03 angular range (top). Voltage profile of $\mathrm{Na}_{3} \mathrm{~V}_{2}\left(\mathrm{PO}_{4}\right)_{3}$ during the first cycle and $V / Z$ evolution of the $\mathrm{Na}_{x} \mathrm{~V}_{2}\left(\mathrm{PO}_{4}\right)_{3}(\mathrm{x}=1,2,3$, and 4) phases (middle). The corresponding phase weights (bottom). b) Details of the SXRPD patterns, upon 
$\mathrm{Na}^{+}$extraction from $\mathrm{Na}_{3} \mathrm{~V}_{2}\left(\mathrm{PO}_{4}\right)_{3}$ to $\mathrm{Na}_{1} \mathrm{~V}_{2}\left(\mathrm{PO}_{4}\right)_{3}$, (top), upon $\mathrm{Na}^{+}$re-insertion from $\mathrm{Na}_{1} \mathrm{~V}_{2}\left(\mathrm{PO}_{4}\right)_{3}$ to $\mathrm{Na}_{3} \mathrm{~V}_{2}\left(\mathrm{PO}_{4}\right)_{3}$ (middle), and upon one additional $\mathrm{Na}^{+}$insertion from $\mathrm{Na}_{3} \mathrm{~V}_{2}\left(\mathrm{PO}_{4}\right)_{3}$ to $\mathrm{Na}_{4} \mathrm{~V}_{2}\left(\mathrm{PO}_{4}\right)_{3}$ (bottom). $\mathrm{Na}_{x}\left(\mathrm{x}=1,2,3\right.$, and 4) refers to $\mathrm{Na}_{x} \mathrm{~V}_{2}\left(\mathrm{PO}_{4}\right)_{3}$.

When the pristine $\mathrm{Na}_{3} \mathrm{~V}_{2}\left(\mathrm{PO}_{4}\right)_{3}$ phase re-appears during discharge, the reaction mainly occurs through a two-phase reaction mechanism but a slight peak-shift to lower angles (Figure $6 \mathbf{b}$ ) and an increase of $V / Z$ were observed, which indicates that a partial solid solution mechanism is also involved. This behavior is typically observed in $\mathrm{Na}_{3} \mathrm{~V}_{2}\left(\mathrm{PO}_{4}\right)_{3}{ }^{17-22}$ and other electrode materials, such as, $\mathrm{Na}_{3} \mathrm{Al}_{0.5} \mathrm{~V}_{1.5}\left(\mathrm{PO}_{4}\right)_{3},{ }^{51} \quad \mathrm{Na}_{4} \mathrm{MnCr}\left(\mathrm{PO}_{4}\right)_{3},{ }^{52}$ $\mathrm{Na}_{2} \mathrm{TiV}\left(\mathrm{PO}_{4}\right)_{3},{ }^{53}$ and $\mathrm{LiVOPO}_{4},{ }^{54}$ which involve a two-phase reaction mechanism upon cycling. When multiple phase boundaries are possibly observed between two end-members, leading to strains, slight changes in cell parameters can occur as a signature of these strains. ${ }^{51,53,54}$ Nevertheless, the SXRPD pattern of $\mathrm{Na}_{3} \mathrm{~V}_{2}\left(\mathrm{PO}_{4}\right)_{3}$ is maintained after the re-sodiation, implying that the overall electrochemical reaction is highly reversible.

From the phase fraction analysis, it is clear that the $\mathrm{Na}_{2} \mathrm{~V}_{2}\left(\mathrm{PO}_{4}\right)_{3}$ phase could not be observed as completely isolated but rather coexisting together with the $\mathrm{Na}_{1} \mathrm{~V}_{2}\left(\mathrm{PO}_{4}\right)_{3}$ and $\mathrm{Na}_{3} \mathrm{~V}_{2}\left(\mathrm{PO}_{4}\right)_{3}$ ones. The maximum phase fraction of the $\mathrm{Na}_{2} \mathrm{~V}_{2}\left(\mathrm{PO}_{4}\right)_{3}$ phase observed during charge was of 30.1(8) wt\% while it reached 77(1) wt\% during discharge. The asymmetric behaviors in the appearance of the intermediate phase during charge and discharge were also observed in other studies of $\mathrm{Na}_{3} \mathrm{~V}_{2}\left(\mathrm{PO}_{4}\right)_{3}{ }^{18-20}$ and of LiFePO${ }_{4}{ }^{30,32,35,36}$. The intermediate phases of $\mathrm{Na}_{x} \mathrm{~V}_{2}\left(\mathrm{PO}_{4}\right)_{3}$ and $\mathrm{Li}_{x} \mathrm{FePO}_{4}$ are more visible during charge in some cases ${ }^{18-20,30,36}$ and during discharge in other cases $^{20,32,35}$. Zakharkin et al. investigated three different synthesis routes for preparing $\mathrm{Na}_{3} \mathrm{~V}_{2}\left(\mathrm{PO}_{4}\right)_{3}$ with different precursors resulting in different intensities of the XRD reflections of the $\mathrm{Na}_{2} \mathrm{~V}_{2}\left(\mathrm{PO}_{4}\right)_{3}$ intermediate phase. ${ }^{20}$ Depending on the synthesis procedures, the $\mathrm{Na}_{2} \mathrm{~V}_{2}\left(\mathrm{PO}_{4}\right)_{3}$ phase was either not observed, or observed only during charge, or observed during both charge and discharge. ${ }^{20}$ These observations may suggest that the intermediate phase could be metastable/transient. Further investigations are required to understand the origin of the asymmetric behavior of the $\mathrm{Na}_{2} \mathrm{~V}_{2}\left(\mathrm{PO}_{4}\right)_{3}$ intermediate phase in the $\mathrm{Na}_{3} \mathrm{~V}_{2}\left(\mathrm{PO}_{4}\right)_{3}-\mathrm{Na}_{1} \mathrm{~V}_{2}\left(\mathrm{PO}_{4}\right)_{3}$ system. 
A global overview of cell parameters, $\mathrm{Na}$ site occupancies, and average of $\mathrm{V}$-O bond lengths of $\mathrm{Na}_{x} \mathrm{~V}_{2}\left(\mathrm{PO}_{4}\right)_{3}(\mathrm{x}=1,2,3$, and 4$)$ is summarized in Table 3. For the monoclinic phases, $\mathrm{Na}_{3} \mathrm{~V}_{2}\left(\mathrm{PO}_{4}\right)_{3}$ and $\mathrm{Na}_{2} \mathrm{~V}_{2}\left(\mathrm{PO}_{4}\right)_{3}$, the $a, b$, and $c$ parameters decrease by $1.1,1.38$, and $0.97 \%$, respectively, and a slight increase in the $B$ angle $(0.14 \%)$ is noticed from $x=3$ to 2 in $\mathrm{Na}_{x} \mathrm{~V}_{2}\left(\mathrm{PO}_{4}\right)_{3}$. The two end members $\left(\mathrm{Na}_{4} \mathrm{~V}_{2}\left(\mathrm{PO}_{4}\right)_{3}\right.$ and $\left.\mathrm{Na}_{1} \mathrm{~V}_{2}\left(\mathrm{PO}_{4}\right)_{3}\right)$ crystalize in the same space group $R 3 c$. From the Na-rich phase, $\mathrm{Na}_{4} \mathrm{~V}_{2}\left(\mathrm{PO}_{4}\right)_{3}$, to the $\mathrm{Na}$-poor one, $\mathrm{Na}_{1} \mathrm{~V}_{2}\left(\mathrm{PO}_{4}\right)_{3}$, the a parameter dramatically decreases from $8.94302(10)$ to $8.42631(12) \AA(\Delta a / a=-5.81 \%)$ while the $c$ parameter slightly increases from 21.3609 (4) to $21.4772(6) \AA$ ( $\Delta c / c=0.54 \%$ ). This noticeable anisotropy in the change of cell parameters is closely linked to the occupancies of the $\mathrm{Na}(1)$ and $\mathrm{Na}(2)$ sites.

Table 3. Unit cell parameters, Na occupancy factors, and average $\mathrm{V}-\mathrm{O}$ distances for the compositions $\mathrm{Na}_{\mathrm{x}} \mathrm{V}_{2}\left(\mathrm{PO}_{4}\right)_{3},(\mathrm{x}=1,2,3$, and 4) obtained by Rietveld refinement. See the profiles of the Rietveld refinements for $\mathrm{Na}_{x} \mathrm{~V}_{2}\left(\mathrm{PO}_{4}\right)_{3}(\mathrm{x}=1,3$, and 4$)$ in Figures $\mathbf{S 1 0 - S 1 2}$, and the details of their structural information in Table S4-S6.

\begin{tabular}{|c|c|c|c|c|c|c|c|c|c|c|}
\hline & S.G. & $a$ & B & c & $\beta$ & $v / Z$ & $\begin{array}{l}\mathrm{Na}(1) \\
\text { /f.u. }\end{array}$ & $\begin{array}{l}\mathrm{Na}(2) \\
\text { /f.u. }\end{array}$ & $\begin{array}{c}\text { Total } \\
\mathrm{Na} / \mathrm{f} . u\end{array}$ & $\begin{array}{c}\text { Avg. } \\
\text { V-O (Å) }\end{array}$ \\
\hline $\mathrm{Na}_{4} \mathrm{~V}_{2}\left(\mathrm{PO}_{4}\right)_{3}$ & $R 3 c$ & $8.94302(10)$ & $8.94302(10)$ & ) $21.3609(4)$ & 120 & $246.585(7)$ & $0.97(4)$ & $2.77(7)$ & $3.74(11)$ & $2.078(14)$ \\
\hline $\mathrm{Na}_{3} \mathrm{~V}_{2}\left(\mathrm{PO}_{4}\right)_{3}$ & $C 2 / c$ & $15.4065(3)$ & $8.7288(2)$ & $8.8243(2)$ & $126.1091(16)$ & ) $239.682(10)$ & $0.679(14)$ & $2.27(8)$ & $2.9(1)$ & $2.02(4)$ \\
\hline $\mathrm{Na}_{2} \mathrm{~V}_{2}\left(\mathrm{PO}_{4}\right)_{3}$ & $P 2_{1} / c$ & $15.2377(5)$ & $8.6082(5)$ & $8.7391(4)$ & $126.281(3)$ & $231.02(2)$ & $0.98(4)$ & $1.2(3)$ & $2.2(3)$ & 1.99(9) \\
\hline $\mathrm{Na}_{1} \mathrm{~V}_{2}\left(\mathrm{PO}_{4}\right)_{3}$ & $R 3 c$ & $8.42631(12)$ & $8.42631(12)$ & ) $21.4772(6)$ & 120 & $220.105(8)$ & $0.96(4)$ & 0 & $0.96(4)$ & $1.91(2)$ \\
\hline
\end{tabular}

Generally, $\mathrm{Na}^{+}$insertion in the NASICON structure increases the $a$ parameter and decreases the $c$ parameter (in hexagonal axes). When the $\mathrm{Na}(1)$ site is depopulated, the $c$ parameter increases mainly due to an increasing repulsion between parallel $\mathrm{O}_{3}$ triangular faces of the $\mathrm{MO}_{6}$ octahedra through the $\mathrm{Na}(1)$ site, as less screened by the $\mathrm{Na}^{+}$ions. ${ }^{15,52,55-57}$ 


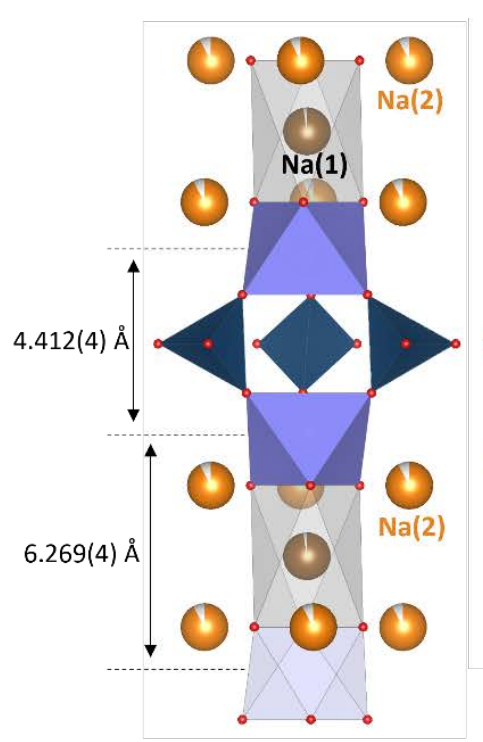

$\mathrm{Na}_{4} \mathrm{~V}_{2}\left(\mathrm{PO}_{4}\right)_{3}$

$(R \overline{3} C)$

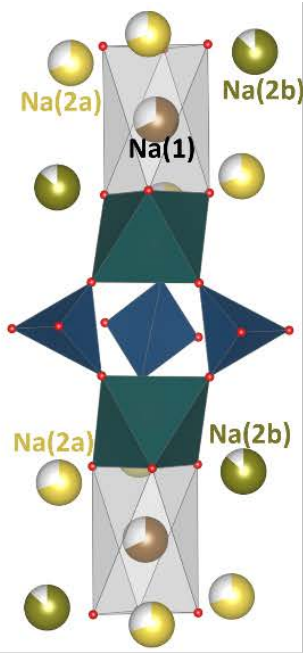

$\mathrm{Na}_{3} \mathrm{~V}_{2}\left(\mathrm{PO}_{4}\right)_{3}$

$(C 2 / c)$
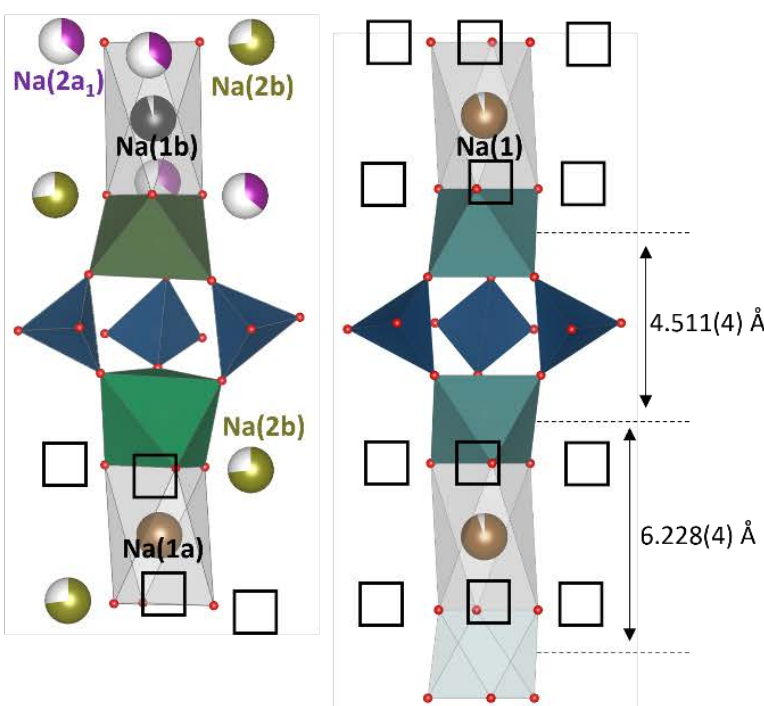

$\mathrm{Na}_{2} \mathrm{~V}_{2}\left(\mathrm{PO}_{4}\right)_{3}$

$\left(P 2_{1} / C\right)$
$\mathrm{Na}_{1} \mathrm{~V}_{2}\left(\mathrm{PO}_{4}\right)_{3}$

$(R \overline{3} C)$

Figure 7. Illustration of the lantern units with adjacent $\mathrm{Na}$ ions of the compositions $\mathrm{Na}_{x} \mathrm{~V}_{2}\left(\mathrm{PO}_{4}\right)_{3}(\mathrm{x}=$ $1,2,3$, and 4). Black squares represent $\mathrm{Na}$ vacancies. The distances shown in $\mathrm{Na}_{4} \mathrm{~V}_{2}\left(\mathrm{PO}_{4}\right)_{3}$ and $\mathrm{Na}_{1} \mathrm{~V}_{2}\left(\mathrm{PO}_{4}\right)_{3}$ indicate $\mathrm{V}-\mathrm{V}$ distances either through the $\mathrm{Na}(1)$ site or within the lantern unit.

In the case of $\mathrm{Na}_{x} \mathrm{~V}_{2}\left(\mathrm{PO}_{4}\right)_{3}$, the distances between adjacent $\mathrm{VO}_{6}$ octahedra through the $\mathrm{Na}(1)$ site along [001] hexagonal remain nearly constant, 6.269(4) $\AA$ in $\mathrm{Na}_{4} \mathrm{~V}_{2}\left(\mathrm{PO}_{4}\right)_{3}$ and 6.228(4) $\AA$ in $\mathrm{Na}_{1} \mathrm{~V}_{2}\left(\mathrm{PO}_{4}\right)_{3}$, (Figure 7), as the $\mathrm{Na}(1)$ site stays fully occupied $(0.96(4) \rightarrow 0.97(4)$ when $\mathrm{x}$ varies from 4 to 1 in $\left.\mathrm{Na}_{x} \mathrm{~V}_{2}\left(\mathrm{PO}_{4}\right)_{3}\right)$. As a consequence, the $c$ parameter undergoes no significant variation. The main reason for the slight increase in the $c$ parameter may be the stronger repulsion of neighboring between $\mathrm{VO}_{6}$ octahedra within the lantern unit when vanadium is oxidized from $\mathrm{V}^{2.5+}$ to $\mathrm{V}^{4+}$. Therefore, the $\mathrm{V}-\mathrm{V}$ distances within the lantern unit themselves increase from 4.412(4) to 4.511(4) $\AA$ (Figure 7). Similar evolutions of the $a$ and $c$ cell parameters were found in other NASICON positive electrode materials but with a more pronounced increase of the $c$ parameter: $\Delta a / a=-6.1 \%$ and $\Delta c / c=2.4 \%$ in $\mathrm{Na}_{x} \mathrm{MnV}\left(\mathrm{PO}_{4}\right)_{3},{ }^{15}$ and $\Delta a / a=-4.9 \%$ and $\Delta c / c=2.2 \%$ in $\mathrm{Na} \times \mathrm{MnCr}\left(\mathrm{PO}_{4}\right)_{3},{ }^{52}$ when $\mathrm{x}$ varies from 4 to 1 . Unlike the case of $\mathrm{Na}_{x} \mathrm{~V}_{2}\left(\mathrm{PO}_{4}\right)_{3}$, a much depopulated $\mathrm{Na}(1)$ site is observed in $\mathrm{Na} \times \mathrm{MnV}\left(\mathrm{PO}_{4}\right)_{3}$ (from 1 to $0.49(1)$ when $x$ varies from 4 to 1$)$ inducing stronger repulsions between the $(\mathrm{Mn}, \mathrm{V}) \mathrm{O}_{6}$ octahedra through the $\mathrm{Na}(1)$ site, and thus a remarkable increase of the $c$ parameter. ${ }^{15,55}$ 
Overall, the value of $V / Z$ gradually decreases with a decreasing number of $\mathrm{Na}^{+}$ions in the structure (driving a progressive oxidation of vanadium), from 246.585(7), 239.682(10), 231.02(2), and to 220.105(8) $\AA^{3}$ when $x$ varies from 4 to 1 in $\mathrm{Na}_{x} \mathrm{~V}_{2}\left(\mathrm{PO}_{4}\right)_{3}$. The lattice mismatch in the phase transition between $\mathrm{Na}_{3} \mathrm{~V}_{2}\left(\mathrm{PO}_{4}\right)_{3}$ and $\mathrm{Na}_{1} \mathrm{~V}_{2}\left(\mathrm{PO}_{4}\right)_{3}(\Delta V / V=8.2 \%)$ is noticeably reduced when $\mathrm{Na}_{2} \mathrm{~V}_{2}\left(\mathrm{PO}_{4}\right)_{3}$ is invoked $\left(\Delta V / V=3.6\right.$, and $4.7 \%$, for $\mathrm{Na}_{3} \mathrm{~V}_{2}\left(\mathrm{PO}_{4}\right)_{3} \rightarrow$ $\mathrm{Na}_{2} \mathrm{~V}_{2}\left(\mathrm{PO}_{4}\right)_{3}$, and $\mathrm{Na}_{2} \mathrm{~V}_{2}\left(\mathrm{PO}_{4}\right)_{3} \rightarrow \mathrm{Na}_{1} \mathrm{~V}_{2}\left(\mathrm{PO}_{4}\right)_{3}$, respectively). The reduced lattice mismatch enables a rapid phase transition between $\mathrm{Na}_{3} \mathrm{~V}_{2}\left(\mathrm{PO}_{4}\right)_{3}$ and $\mathrm{Na}_{1} \mathrm{~V}_{2}\left(\mathrm{PO}_{4}\right)_{3}$ via $\mathrm{Na}_{2} \mathrm{~V}_{2}\left(\mathrm{PO}_{4}\right)_{3}$ by lowering their nucleation energies. ${ }^{30}$

The average $\mathrm{V}-\mathrm{O}$ bond distances consequently show a gradual decrease from 2.076(14), to 2.02(4), to 1.99(9), and to 1.91(2) $\AA$ when $\mathrm{x}$ in $\mathrm{Na}_{x} \mathrm{~V}_{2}\left(\mathrm{PO}_{4}\right)_{3}$ changes from 4 to 1 . The details of (not average but individual) V-O bond distances in $\mathrm{Na}_{x} \mathrm{~V}_{2}\left(\mathrm{PO}_{4}\right)_{3}$ are shown in Table S2. Also, the volumes of the $\mathrm{VO}_{6}$ octahedra decrease in parallel from 11.69 , to 10.73 , to 10.16 , and to $9.15 \AA^{3}$, respectively $\left(\Delta V_{\text {oct }} / V_{\text {oct }}=21.7 \%\right)$. As a comparison, the volume of the $(\mathrm{Mn}, \mathrm{V}) \mathrm{O}_{6}$ octahedra decreases about $23.8 \%$ when $x$ varies from 4 to 1 in $\mathrm{Na} \times \mathrm{MnV}\left(\mathrm{PO}_{4}\right)_{3}{ }^{15}$ Furthermore, as $\mathrm{x}$ in $\mathrm{Na}_{x} \mathrm{~V}_{2}\left(\mathrm{PO}_{4}\right)_{3}$ decreases from 4 to 1 , the average oxidation states of vanadium obtained by BVS calculation are 2.44(4), 2.92(11), 3.3(3) and 3.87(8), respectively, showing a good agreement with the average vanadium oxidation states expected for each composition (i.e., 2.5, 3, 3.5, and 4, respectively).

When it comes to the number of $\mathrm{Na}^{+}$in the $\mathrm{Na}(1)$ and $\mathrm{Na}(2)$ sites per formula unit (Table 3), our findings establish that the $\mathrm{Na}(1)$ site is almost fully occupied in all compositions except for $\mathrm{Na}_{3} \mathrm{~V}_{2}\left(\mathrm{PO}_{4}\right)_{3}$ as the occupancy factor of $\mathrm{Na}(1)$ site is $0.679(14)$. For the $\mathrm{Na}(2)$ site, when the $\mathrm{Na}^{+}$content changes from $\mathrm{x}=4$ to 1 in $\mathrm{Na}_{x} \mathrm{~V}_{2}\left(\mathrm{PO}_{4}\right)_{3}$, the occupancy factor gradually decreases from almost $100 \%$ down to 0 \%. This evidence appears in good agreement with the computational analysis on $\mathrm{Na}(1)$ and $\mathrm{Na}(2)$ sites at room temperature. ${ }^{49}$ Other NASICON-type materials also show similar trends, i.e. the $\mathrm{Na}(1)$ site tends to keep its high occupancies while the $\mathrm{Na}(2)$ site is populated or depopulated depending on the compositions. ${ }^{8,9,14-16}$ Overall, the refined total number of $\mathrm{Na}^{+}$per formula unit shows very good agreement with the expected compositions. 
The detailed evolution on the $\mathrm{Na}^{+}$distributions around the lantern units of the four compositions $\left(\mathrm{Na}_{\mathrm{x}} \mathrm{V}_{2}\left(\mathrm{PO}_{4}\right)_{3}\right.$, with $\mathrm{x}=1,2,3$, and 4) is illustrated in Figure 7. The $\mathrm{Na}(2)$ site in $\mathrm{Na}_{4} \mathrm{~V}_{2}\left(\mathrm{PO}_{4}\right)_{3}(R 3 c)$ splits into the two $\mathrm{Na}(2)$ positions, $\mathrm{Na}(2 \mathrm{a})$ and $\mathrm{Na}(2 \mathrm{~b})$, in $\mathrm{Na}_{3} \mathrm{~V}_{2}\left(\mathrm{PO}_{4}\right)_{3}$ $(C 2 / c)$. Then, from $\mathrm{Na}_{3} \mathrm{~V}_{2}\left(\mathrm{PO}_{4}\right)_{3}$ to $\mathrm{Na}_{2} \mathrm{~V}_{2}\left(\mathrm{PO}_{4}\right)_{3}\left(P 2_{1} / c\right)$, the $\mathrm{Na}(1)$ site splits into the $\mathrm{Na}(1 \mathrm{a})$ and $\mathrm{Na}(1 \mathrm{~b})$ positions that are almost fully occupied in $\mathrm{Na}_{2} \mathrm{~V}_{2}\left(\mathrm{PO}_{4}\right)_{3}$. The $\mathrm{Na}(2 \mathrm{a})$ position also further splits into $\mathrm{Na}\left(2 \mathrm{a}_{1}\right)$ and $\mathrm{Na}\left(2 \mathrm{a}_{2}\right)$ in $\mathrm{Na}_{2} \mathrm{~V}_{2}\left(\mathrm{PO}_{4}\right)_{3}$, but the $\mathrm{Na}\left(2 \mathrm{a}_{2}\right)$ is found to be empty. Finally, from $\mathrm{Na}_{2} \mathrm{~V}_{2}\left(\mathrm{PO}_{4}\right)_{3}$ to $\mathrm{Na}_{1} \mathrm{~V}_{2}\left(\mathrm{PO}_{4}\right)_{3}$, the structure is back to rhombohedral unit cell (R3c), having the $\mathrm{Na}(2)$ site fully emptied. It is interesting that from $\mathrm{Na}_{4} \mathrm{~V}_{2}\left(\mathrm{PO}_{4}\right)_{3}$ to $\mathrm{Na}_{2} \mathrm{~V}_{2}\left(\mathrm{PO}_{4}\right)_{3}$, the $\mathrm{Na}(2 \mathrm{~b})$ position tends to be more occupied than the $\mathrm{Na}(2 \mathrm{a})$ positions. This may be related to different connectivities of $\mathrm{Na}(2 \mathrm{a})$ and $\mathrm{Na}(2 \mathrm{~b})$ with the $\mathrm{Na}(1)$ site. Figure 8 shows the polyhedra constructed from $\mathrm{Na}$ and $\mathrm{O}$ atoms in $\mathrm{Na}_{3} \mathrm{~V}_{2}\left(\mathrm{PO}_{4}\right)_{3}$ or $\mathrm{Na}_{2} \mathrm{~V}_{2}\left(\mathrm{PO}_{4}\right)_{3}$. The connectivity between $\mathrm{Na}(2 \mathrm{a})$ and $\mathrm{Na}(1)$ forms distinct $2 \mathrm{D} \mathrm{Na}{ }^{+}$diffusion paths parallel to the (100) plane, while the connectivity between $\mathrm{Na}(2 \mathrm{~b})$ and $\mathrm{Na}(1)$ results in $1 \mathrm{D} \mathrm{Na}^{+}$diffusion chains along the [101] direction. This suggests that $\mathrm{Na}^{+}$ions in $\mathrm{Na}(2 \mathrm{a})$ position may show easier migration than those in $\mathrm{Na}(2 \mathrm{~b})$ position, and therefore explaining the lower occupancy factor observed for $\mathrm{Na}(2 \mathrm{a})$ than $\mathrm{Na}(2 \mathrm{~b})$. 


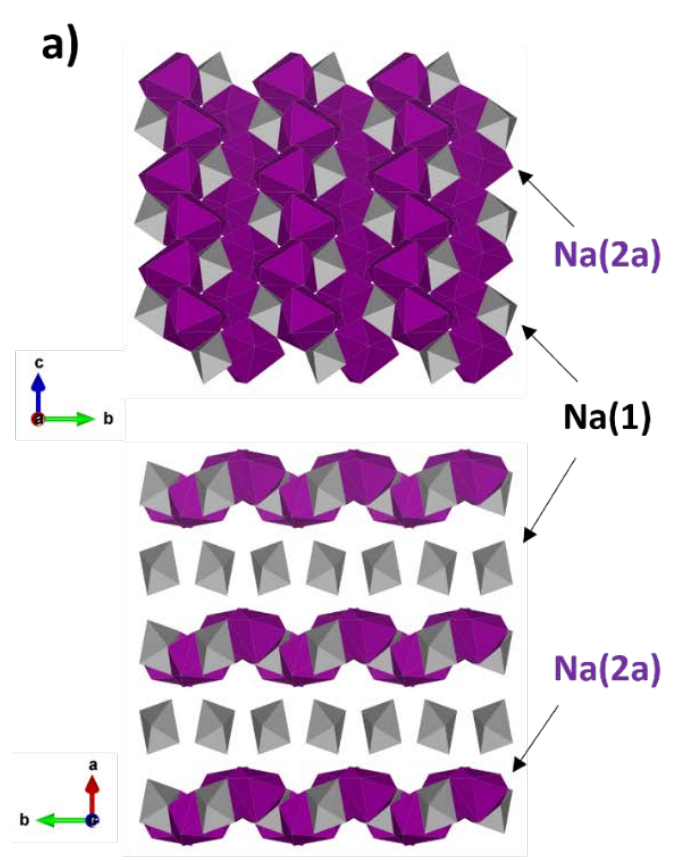

2D Na+ diffusion path (parallel to (100) plane)

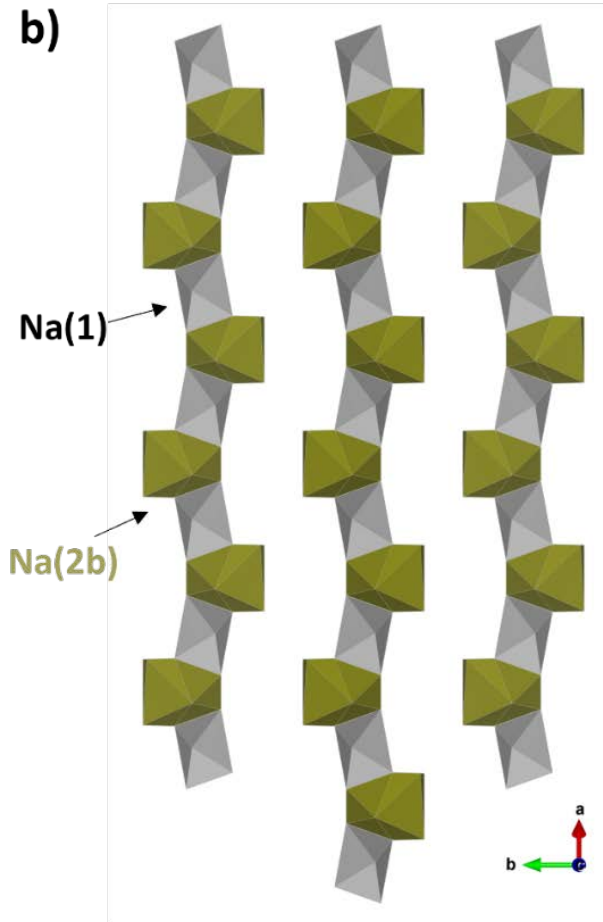

1D $\mathrm{Na}^{+}$diffusion path (along [101] direction)

Figure 8. Different connectivities of (a) $\mathrm{Na}(2 \mathrm{a})$ with $\mathrm{Na}(1)$, and (b) $\mathrm{Na}(2 \mathrm{~b})$ with $\mathrm{Na}$ (1) in $\mathrm{Na}_{3} \mathrm{~V}_{2}\left(\mathrm{PO}_{4}\right)_{3}$ or $\mathrm{Na}_{2} \mathrm{~V}_{2}\left(\mathrm{PO}_{4}\right)_{3}$. The polyhedra are constructed from $\mathrm{Na}$ and $\mathrm{O}$ atoms.

\section{Conclusions}

In this study, we report for the first time the crystal chemistry of the new intermediate $\mathrm{Na}_{2} \mathrm{~V}_{2}\left(\mathrm{PO}_{4}\right)_{3}$ composition as well as the electrochemical reaction mechanisms of $\mathrm{Na}_{\times} \mathrm{V}_{2}\left(\mathrm{PO}_{4}\right)_{3}$ $(1 \leq x \leq 4)$ including the intermediate phase. The appearance of the $\mathrm{Na}_{2} \mathrm{~V}_{2}\left(\mathrm{PO}_{4}\right)_{3}$ phase occurs in a non-equilibrium battery operation and it is better observed with a higher current density (i.e., non-equilibrium state). The results of Rietveld refinement suggest that the crystal structure of $\mathrm{Na}_{2} \mathrm{~V}_{2}\left(\mathrm{PO}_{4}\right)_{3}$ crystalizes in a primitive (monoclinic) cell with the possible space groups of $P 2_{1} / c$ (Model 1) or $P 2 / c$ (Model 2) rather than rhombohedral (R3c) or monoclinic $(C 2 / c)$ cells of other $\mathrm{Na}_{x} \mathrm{~V}_{2}\left(\mathrm{PO}_{4}\right)_{3}(\mathrm{x}=1,3$, and 4) compositions. The main difference between the two structure models proposed for $\mathrm{Na}_{2} \mathrm{~V}_{2}\left(\mathrm{PO}_{4}\right)_{3}$ is ascribed to different vanadium environments. As a symmetry is reduced in the $\mathrm{Na}_{2} \mathrm{~V}_{2}\left(\mathrm{PO}_{4}\right)_{3}$, the vanadium site splits into two Wyckoff positions. The structure with the space group $P 2_{1} / c$ 
(Model 1) contains a single lantern unit with a random distribution of $\mathrm{V}^{3+}$ and $\mathrm{V}^{4+}$ types over two vanadium positions. The structure with the space group $P 2 / c$ (Model 2) contains two different lantern units, each vanadium position forming its own lantern unit, with a possible charge ordering between $\mathrm{V}^{3+}$ and $\mathrm{V}^{4+}$. For the sodium sites, the $\mathrm{Na}(1)$ site is almost fully occupied for both structure models. The $\mathrm{Na}(2)$ site splits into several positions, in which one of the splitting $\mathrm{Na}(2)$ position $\left[\mathrm{Na}\left(2 \mathrm{a}_{2}\right)\right]$ is found to be a vacancy in the structure Model 1 whereas the four splitting $\mathrm{Na}(2)$ positions are all partially filled in the structure Model 2. The structure independently predicted by our DFT simulations at $0 \mathrm{~K}$ also shows a vanadium charge ordering as well as a full $\mathrm{Na}^{+} /$vacancy ordering. A fully ordered $\mathrm{Na}^{+}$at $0 \mathrm{~K}$ becomes partially ordered at room temperature. These different $\mathrm{Na}^{+}$distributions suggest that the $\mathrm{Na}_{2} \mathrm{~V}_{2}\left(\mathrm{PO}_{4}\right)_{3}$ phase can have possible phase transitions versus temperature due to $\mathrm{Na}^{+}$ order/disorder phenomena. Furthermore, $\mathrm{Na}^{+}$ions in $\mathrm{Na}(2 \mathrm{a})$ position can diffuse more easily than those in $\mathrm{Na}(2 \mathrm{~b})$ position due to different connectivities with $\mathrm{Na}(1)$ site. The intermediate $\mathrm{Na}_{2} \mathrm{~V}_{2}\left(\mathrm{PO}_{4}\right)_{3}$ phase appears by reducing the lattice mismatch between $\mathrm{Na}_{3} \mathrm{~V}_{2}\left(\mathrm{PO}_{4}\right)_{3}$ and $\mathrm{Na}_{1} \mathrm{~V}_{2}\left(\mathrm{PO}_{4}\right)_{3}$ phases lowering their nucleation energy thus beneficial for a high-rate performance. This study opens the door to a better understanding of the behavior of $\mathrm{Na}_{3} \mathrm{~V}_{2}\left(\mathrm{PO}_{4}\right)_{3}$ electrode upon cycling when the intermediate phase is involved. We believe our findings in this work will encourage researchers to further investigate the nature of the new $\mathrm{Na}_{2} \mathrm{~V}_{2}\left(\mathrm{PO}_{4}\right)_{3}$ phase.

\section{Supporting Information}

SEM images, TGA, synchrotron powder XRD patterns, operando XRD data, and detailed crystallographic information 


\section{Acknowledgements}

The authors thank Emmanuel Petit (ICMCB) for SEM measurements, and Matthieu Courty (LRCS) for the TGA analysis. The authors also acknowledge ALBA (Barcelona, Spain) for synchrotron X-ray diffraction experiments on the MSPD beamline (proposal number 20200024218). S. P. acknowledges Jon Serrano for a fruitful discussion on Rietveld refinements. The authors are grateful to the ANRT and TIAMAT for the funding (CIFRE grant) of S. P.'s PhD thesis. We acknowledge the financial support of Région Nouvelle Aquitaine and of the French National Research Agency (STORE-EX Labex Project ANR-10-LABX-76-01). P. C., C. M., J.-N. C. and Z. D. are grateful to the ANR-NRF NRF2019-NRF-ANR073 NaMASTER. P. C. and Z. D. acknowledge funding from the National Research Foundation under the NRF Fellowship NRFF12-2020-0012. Part of the computational work was performed using resources of the National Supercomputing Centre, Singapore (https://www.nscc.sg). 


\section{References}

(1) Masquelier, C.; Croguennec, L. Polyanionic (Phosphates, Silicates, Sulfates) Frameworks as Electrode Materials for Rechargeable Li (or Na) Batteries. Chem. Rev. 2013, 113 (8), 6552-6591. https://doi.org/10.1021/cr3001862.

(2) Hasa, I.; Mariyappan, S.; Saurel, D.; Adelhelm, P.; Koposov, A. Y.; Masquelier, C.; Croguennec, L.; Casas-Cabanas, M. Challenges of Today for Na-Based Batteries of the Future: From Materials to Cell Metrics. J. Power Sources 2021, 482 (August 2020), 228872. https://doi.org/10.1016/j.jpowsour.2020.228872.

(3) Jian, Z.; Hu, Y. S.; Ji, X.; Chen, W. NASICON-Structured Materials for Energy Storage. Adv. Mater. 2017, 29 (20), 1-16. https://doi.org/10.1002/adma.201601925.

(4) Chen, S.; Wu, C.; Shen, L.; Zhu, C.; Huang, Y.; Xi, K.; Maier, J.; Yu, Y. Challenges and Perspectives for NASICON-Type Electrode Materials for Advanced Sodium-Ion Batteries. Adv. Mater. 2017, 29 (48), 1-21. https://doi.org/10.1002/adma.201700431.

(5) Rajagopalan, R.; Zhang, Z.; Tang, Y.; Jia, C.; Ji, X.; Wang, H. Understanding Crystal Structures, Ion Diffusion Mechanisms and Sodium Storage Behaviors of NASICON Materials. Energy Storage Mater. 2021, 34 (May 2020), 171-193. https://doi.org/10.1016/j.ensm.2020.09.007.

(6) Singh, B.; Wang, Z.; Park, S.; Gautam, G. S.; Chotard, J. N.; Croguennec, L.; Carlier, D.; Cheetham, A. K.; Masquelier, C.; Canepa, P. A Chemical Map of NaSICON Electrode Materials for Sodium-Ion Batteries. J. Mater. Chem. A 2021, 9 (1), 281-292. https://doi.org/10.1039/d0ta10688g.

(7) Zhang, B.; Ma, K.; Lv, X.; Shi, K.; Wang, Y.; Nian, Z.; Li, Y.; Wang, L.; Dai, L.; He, Z. Recent Advances of NASICON-Na $\mathrm{V}_{2}\left(\mathrm{PO}_{4}\right)_{3}$ as Cathode for Sodium-Ion Batteries: Synthesis, Modifications, and Perspectives. J. Alloys Compd. 2021, 867, 159060. https://doi.org/10.1016/j.jallcom.2021.159060.

(8) Bui, K. M.; Dinh, V. A.; Okada, S.; Ohno, T. Hybrid Functional Study of the NASICONType $\mathrm{Na}_{3} \mathrm{~V}_{2}\left(\mathrm{PO}_{4}\right)_{3}$ : Crystal and Electronic Structures, and Polaron-Na Vacancy Complex Diffusion. Phys. Chem. Chem. Phys. 2015, 17 (45), 30433-30439. https://doi.org/10.1039/c5cp05323d.

(9) Song, W.; Cao, X.; Wu, Z.; Chen, J.; Huangfu, K.; Wang, X.; Huang, Y.; Ji, X. A Study into 
the Extracted Ion Number for NASICON Structured $\mathrm{Na}_{3} \mathrm{~V}_{2}\left(\mathrm{PO}_{4}\right)_{3}$ in Sodium-Ion Batteries. Phys. Chem. Chem. Phys. 2014, 16 (33), 17681-17687. https://doi.org/10.1039/c4cp01821d.

(10) Saravanan, K.; Mason, C. W.; Rudola, A.; Wong, K. H.; Balaya, P. The First Report on Excellent Cycling Stability and Superior Rate Capability of $\mathrm{Na}_{3} \mathrm{~V}_{2}\left(\mathrm{PO}_{4}\right)_{3}$ for Sodium Ion Batteries. Adv. Energy Mater. 2013, 3 (4), 444-450. https://doi.org/10.1002/aenm.201200803.

(11) Zheng, Q.; Yi, H.; Li, X.; Zhang, H. Progress and Prospect for NASICON-Type $\mathrm{Na}_{3} \mathrm{~V}_{2}\left(\mathrm{PO}_{4}\right)_{3}$ for Electrochemical Energy Storage. J. Energy Chem. 2018, 27 (6), 15971617. https://doi.org/10.1016/j.jechem.2018.05.001.

(12) Zhang, X.; Rui, X.; Chen, D.; Tan, H.; Yang, D.; Huang, S.; Yu, Y. $\mathrm{Na}_{3} \mathrm{~V}_{2}\left(\mathrm{PO}_{4}\right)_{3}$ : An Advanced Cathode for Sodium-Ion Batteries. Nanoscale 2019, 11 (6), 2556-2576. https://doi.org/10.1039/c8nr09391a.

(13) Lim, S. Y.; Kim, H.; Shakoor, R. A.; Jung, Y.; Choi, J. W. Electrochemical and Thermal Properties of NASICON Structured $\mathrm{Na}_{3} \mathrm{~V}_{2}\left(\mathrm{PO}_{4}\right)_{3}$ as a Sodium Rechargeable Battery Cathode: A Combined Experimental and Theoretical Study . J. Electrochem. Soc. 2012, 159 (9), A1393-A1397. https://doi.org/10.1149/2.015209jes.

(14) Kabbour, H.; Coillot, D.; Colmont, M.; Masquelier, C.; Mentré, O. $\alpha-\mathrm{Na}_{3} \mathrm{M}_{2}\left(\mathrm{PO}_{4}\right)_{3}(\mathrm{M}=$ Ti, Fe): Absolute Cationic Ordering in NASICON-Type Phases. J. Am. Chem. Soc. 2011, 133 (31), 11900-11903. https://doi.org/10.1021/ja204321y.

(15) Chen, F.; Kovrugin, V. M.; David, R.; Mentré, O.; Fauth, F.; Chotard, J.-N.; Masquelier, C. A NASICON-Type Positive Electrode for Na Batteries with High Energy Density: $\mathrm{Na}_{4} \mathrm{MnV}\left(\mathrm{PO}_{4}\right)_{3} \quad$. Small Methods 2018, 1800218, 1800218. https://doi.org/10.1002/smtd.201800218.

(16) Wang, Q.; Zhang, M.; Zhou, C.; Chen, Y. Concerted Ion-Exchange Mechanism for Sodium Diffusion and Its Promotion in $\mathrm{Na}_{3} \mathrm{~V}_{2}\left(\mathrm{PO}_{4}\right)_{3}$ Framework. J. Phys. Chem. C 2018, 122 (29), 16649-16654. https://doi.org/10.1021/acs.jpcc.8b06120.

(17) Zhang, G.; Xiong, T.; Yan, M.; Xu, Y.; Ren, W.; Xu, X.; Wei, Q.; Mai, L. In Operando Probing of Sodium-Incorporation in NASICON Nanomaterial: Asymmetric Reaction and Electrochemical Phase Diagram. Chem. Mater. 2017, 29 (19), 8057-8064. 
https://doi.org/10.1021/acs.chemmater.7b00957.

(18) Yao, X.; Zhu, Z.; Li, Q.; Wang, X.; Xu, X.; Meng, J.; Ren, W.; Zhang, X.; Huang, Y.; Mai, L. 3.0 v High Energy Density Symmetric Sodium-Ion Battery: $\mathrm{Na}_{4} \mathrm{~V}_{2}\left(\mathrm{PO}_{4}\right)_{3} \| \mathrm{Na}_{3} \mathrm{~V}_{2}\left(\mathrm{PO}_{4}\right)_{3}$. ACS Appl. Mater. Interfaces 2018, $10 \quad$ (12), 10022-10028. https://doi.org/10.1021/acsami.7b16901.

(19) Wei, C.; Luo, F.; Zhang, C.; Gao, H.; Niu, J.; Ma, W.; Bai, Y.; Zhang, Z. Voltage WindowDependent Electrochemical Performance and Reaction Mechanisms of $\mathrm{Na}_{3} \mathrm{~V}_{2}\left(\mathrm{PO}_{4}\right)_{3}$ Cathode for High-Capacity Sodium Ion Batteries. Ionics (Kiel). 2020, 26 (5), 23432351. https://doi.org/10.1007/s11581-019-03363-0.

(20) Zakharkin, M. V; Drozhzhin, O. A.; Ryazantsev, S. V; Chernyshov, D.; Kirsanova, M. A.; Mikheev, I. V; Pazhetnov, E. M.; Antipov, E. V; Stevenson, K. J. Electrochemical Properties and Evolution of the Phase Transformation Behavior in the NASICON-type $\mathrm{Na}_{3+\mathrm{x}} \mathrm{Mn}_{\mathrm{x}} \mathrm{V}_{2-\mathrm{x}}\left(\mathrm{PO}_{4}\right)_{3}(0 \leq \mathrm{x} \leq 1)$ Cathodes for Na-lon Batteries. J. Power Sources 2020, 470 (February), 228231. https://doi.org/10.1016/j.jpowsour.2020.228231.

(21) Jian, Z.; Han, W.; Lu, X.; Yang, H.; Hu, Y. S.; Zhou, J.; Zhou, Z.; Li, J.; Chen, W.; Chen, D.; et al. Superior Electrochemical Performance and Storage Mechanism of $\mathrm{Na}_{3} \mathrm{~V}_{2}\left(\mathrm{PO}_{4}\right)_{3}$ Cathode for Room-Temperature Sodium-Ion Batteries. Adv. Energy Mater. 2013, 3 (2), 156-160. https://doi.org/10.1002/aenm.201200558.

(22) Mirza, S.; Song, Z.; Zhang, H.; Hussain, A.; Zhang, H.; Li, X. A Simple Pre-Sodiation Strategy to Improve the Performance and Energy Density of Sodium Ion Batteries with $\mathrm{Na}_{3} \mathrm{~V}_{2}\left(\mathrm{PO}_{4}\right)_{3}$ as the Cathode Material. J. Mater. Chem. A 2020, 8 (44), 2336823375. https://doi.org/10.1039/d0ta08186h.

(23) UEBOU, Y.; KIYABU, T.; OKADA, S.; YAMAKI, J. Electrochemical Sodium Insertion into the 3D-Framework of $\mathrm{Na}_{3} \mathrm{M}_{2}\left(\mathrm{PO}_{4}\right)_{3}(\mathrm{M}=\mathrm{Fe}, \mathrm{V})$. reports Inst. Adv. Mater. Study Kyushu Univ. 2002, 16, 1-5.

(24) Li, G.; Jiang, D.; Wang, H.; Lan, X.; Zhong, H.; Jiang, Y. Glucose-Assisted Synthesis of $\mathrm{Na}_{3} \mathrm{~V}_{2}\left(\mathrm{PO}_{4}\right)_{3} / \mathrm{C}$ Composite as an Electrode Material for High-Performance Sodium-Ion Batteries. J. Power Sources 2014, 265, 325-334. https://doi.org/10.1016/j.jpowsour.2014.04.054. 
(25) Lim, S. J.; Han, D. W.; Nam, D. H.; Hong, K. S.; Eom, J. Y.; Ryu, W. H.; Kwon, H. S. Structural Enhancement of $\mathrm{Na}_{3} \mathrm{~V}_{2}\left(\mathrm{PO}_{4}\right)_{3} / \mathrm{C}$ Composite Cathode Materials by Pillar Ion Doping for High Power and Long Cycle Life Sodium-Ion Batteries. J. Mater. Chem. A 2014, 2 (46), 19623-19632. https://doi.org/10.1039/c4ta03948c.

(26) Jian, Z.; Sun, Y.; Ji, X. A New Low-Voltage Plateau of $\mathrm{Na}_{3} \mathrm{~V}_{2}\left(\mathrm{PO}_{4}\right)_{3}$ as an Anode for NaIon Batteries. Chem. Commun. 2015, 51 (29), 6381-6383. https://doi.org/10.1039/c5cc00944h.

(27) Jian, Z.; Zhao, L.; Pan, H.; Hu, Y. S.; Li, H.; Chen, W.; Chen, L. Carbon Coated $\mathrm{Na}_{3} \mathrm{~V}_{2}\left(\mathrm{PO}_{4}\right)_{3}$ as Novel Electrode Material for Sodium Ion Batteries. Electrochem. commun. 2012, 14 (1), 86-89. https://doi.org/10.1016/j.elecom.2011.11.009.

(28) Delacourt, C.; Poizot, P.; Tarascon, J. M.; Masquelier, C. The Existence of a Temperature-Driven Solid Solution in $\mathrm{Li}_{x} \mathrm{FePO}_{4}$ for $0 \leq \mathrm{x} \leq 1$. Nat. Mater. 2005, 4 (3), 254-260. https://doi.org/10.1038/nmat1335.

(29) Malik, R.; Zhou, F.; Ceder, G. Kinetics of Non-Equilibrium Lithium Incorporation in LiFePO 4 . Nat. Mater. 2011, 10 (8), 587-590. https://doi.org/10.1038/nmat3065.

(30) Orikasa, Y.; Maeda, T.; Koyama, Y.; Murayama, H.; Fukuda, K.; Tanida, H.; Arai, H.; Matsubara, E.; Uchimoto, Y.; Ogumi, Z. Direct Observation of a Metastable Crystal Phase of $\mathrm{Li}_{x} \mathrm{FePO}_{4}$ under Electrochemical Phase Transition. J. Am. Chem. Soc. 2013, 135 (15), 5497-5500. https://doi.org/10.1021/ja312527x.

(31) Orikasa, Y.; Maeda, T.; Koyama, Y.; Murayama, H.; Fukuda, K.; Tanida, H.; Arai, H.; Matsubara, E.; Uchimoto, Y.; Ogumi, Z. Transient Phase Change in Two Phase Reaction between $\mathrm{LiFePO}_{4}$ and $\mathrm{FePO}_{4}$ under Battery Operation. Chem. Mater. 2013, 25 (7), 1032-1039. https://doi.org/10.1021/cm303411t.

(32) Hao Liu, Fiona C. Strobridge, Olaf J. Borkiewicz, Kamila M. Wiaderek, Karena W. Chapman, Peter J. Chupas, C. P. G. Capturing Metastable Structures during High-Rate Cycling of $\mathrm{LiFePO}_{4}$ Nanoparticle Electrodes. Science (80-. ). 2014, 344 (6191), 14511452. https://doi.org/10.1126/science.1255819.

(33) Nishimura, S. I.; Natsui, R.; Yamada, A. Superstructure in the Metastable Intermediate-Phase $\mathrm{Li}_{2 / 3} \mathrm{FePO}_{4}$ Accelerating the Lithium Battery Cathode Reaction. Angew. Chemie - Int. Ed. 2015, 54 (31), 8939-8942. 
https://doi.org/10.1002/anie.201501165.

(34) Lu, J.; Oyama, G.; Nishimura, S. I.; Yamada, A. Increased Conductivity in the Metastable Intermediate in $\mathrm{Li}_{x} \mathrm{FePO}_{4}$ Electrode. Chem. Mater. 2016, 28 (4), 11011106. https://doi.org/10.1021/acs.chemmater.5b04508.

(35) Takahashi, I.; Mori, T.; Yoshinari, T.; Orikasa, Y.; Koyama, Y.; Murayama, H.; Fukuda, K.; Hatano, M.; Arai, H.; Uchimoto, Y.; et al. Irreversible Phase Transition between $\mathrm{LiFePO}_{4}$ and $\mathrm{FePO}_{4}$ during High-Rate Charge-Discharge Reaction by Operando X-Ray Diffraction. J. Power Sources 2016, 309, 122-126. https://doi.org/10.1016/j.jpowsour.2016.01.077.

(36) Yoshinari, T.; Mori, T.; Otani, K.; Munesada, T.; Yamamoto, K.; Uchiyama, T.; Fukuda, K.; Koyama, Y.; Hagiwara, R.; Orikasa, Y.; et al. Quantitative Elucidation of the NonEquilibrium Phase Transition in $\mathrm{LiFePO}_{4}$ via the Intermediate Phase. Chem. Mater. 2019, 31 (18), 7160-7166. https://doi.org/10.1021/acs.chemmater.9b00834.

(37) Fauth, F.; Peral, I.; Popescu, C.; Knapp, M. The New Material Science Powder Diffraction Beamline at ALBA Synchrotron. Powder Diffr. 2013, 28 (September), S360S370.

(38) Herklotz, M.; Weiß, J.; Ahrens, E.; Yavuz, M.; Mereacre, L.; Kiziltas-Yavuz, N.; Dräger, C.; Ehrenberg, H.; Eckert, J.; Fauth, F.; et al. A Novel High-Throughput Setup for in Situ Powder Diffraction on Coin Cell Batteries. J. Appl. Crystallogr. 2016, 49, 340-345. https://doi.org/10.1107/S1600576715022165.

(39) Kresse, G.; Furthmüller, J. Efficiency of Ab-Initio Total Energy Calculations for Metals and Semiconductors Using a Plane-Wave Basis Set. Comput. Mater. Sci. 1996, 6 (1), 15-50. https://doi.org/10.1016/0927-0256(96)00008-0.

(40) Vargas-Hernández, R. A. Bayesian Optimization for Calibrating and Selecting HybridDensity Functional Models. J. Phys. Chem. A 2020, 124 (20), 4053-4061. https://doi.org/10.1021/acs.jpca.0c01375.

(41) Sun, J.; Ruzsinszky, A.; Perdew, J. Strongly Constrained and Appropriately Normed Semilocal Density Functional. Phys. Rev. Lett. 2015, 115 (3). https://doi.org/10.1103/PhysRevLett.115.036402.

(42) Long, O. Y.; Sai Gautam, G.; Carter, E. A. Evaluating Optimal U for 3d Transition-Metal 
Oxides within the SCAN+ U Framework. Phys. Rev. Mater. 2020, 4 (4), 1-15. https://doi.org/10.1103/PhysRevMaterials.4.045401.

(43) Joubert, D. From Ultrasoft Pseudopotentials to the Projector Augmented-Wave Method. Phys. Rev. B - Condens. Matter Mater. Phys. 1999, 59 (3), 1758-1775. https://doi.org/10.1103/PhysRevB.59.1758.

(44) Chotard, J.-N.; Rousse, G.; David, R.; Mentré, O.; Courty, M.; Masquelier, C. Discovery of a Sodium-Ordered Form of $\mathrm{Na}_{3} \mathrm{~V}_{2}\left(\mathrm{PO}_{4}\right)_{3}$ below Ambient Temperature . Chem. Mater. 2015, 27 (17), 5982-5987. https://doi.org/10.1021/acs.chemmater.5b02092.

(45) Saurel, D.; Pendashteh, A.; Jáuregui, M.; Reynaud, M.; Fehse, M.; Galceran, M.; Casas-Cabanas, M. Experimental Considerations for Operando Metal-Ion Battery Monitoring Using X-ray Techniques. Chemistry-Methods 2021, 1 (6), 249-260. https://doi.org/10.1002/cmtd.202100009.

(46) Boultif, A.; Louër, D. Powder Pattern Indexing with the Dichotomy Method. J. Appl. Crystallogr. 2004, 37 (5), 724-731. https://doi.org/10.1107/S0021889804014876.

(47) Laugier, J. and Bochu, B. CHEKCELL. "LMGP-Suite Suite of Programs for the interpretation of X-ray. Experiments," (ENSP/ Laboratoire des Matériaux et du Génie Physique, BP 46. 38042, Saint Martin d'Hères, France). 2002, http://www.inpg.fr/LMGP and http://www. ccp14.ac.uk/tutorial/Imgp/

(48) Kraus, W.; Nolze, G. POWDER CELL - A Program for the Representation and Manipulation of Crystal Structures and Calculation of the Resulting X-Ray Powder Patterns. J. Appl. Crystallogr. 1996, 29 (3), 301-303. https://doi.org/10.1107/S0021889895014920.

(49) Wang, Z.; Park, S.; Deng, Z.; Carlier, D.; Chotard, J.-N.; Croguennec, L.; Gautam, G. S.; Cheetham, A. K.; Masquelier, C.; Canepa, P. Phase Stability and Sodium-Vacancy Orderings in a NaSICON Electrode. 2021.

(50) Park, S.; Chotard, J. N.; Carlier, D.; Moog, I.; Courty, M.; Duttine, M.; Fauth, F.; Iadecola, A.; Croguennec, L.; Masquelier, C. Crystal Structures and Local Environments of NASICON-Type $\mathrm{Na}_{3} \mathrm{FeV}\left(\mathrm{PO}_{4}\right)_{3}$ and $\mathrm{Na}_{4} \mathrm{FeV}\left(\mathrm{PO}_{4}\right)_{3}$ positive Electrode Materials for $\mathrm{Na}$ Ion Batteries. Chem. Mater. 2021, 33 (13), 5355-5367. https://doi.org/10.1021/acs.chemmater.1c01457. 
(51) Lalère, F.; Seznec, V.; Courty, M.; David, R.; Chotard, J. N.; Masquelier, C. Improving the Energy Density of $\mathrm{Na}_{3} \mathrm{~V}_{2}\left(\mathrm{PO}_{4}\right)_{3}$-Based Positive Electrodes through $\mathrm{V} / \mathrm{Al}$ Substitution. J. Mater. Chem. A 2015, 3 (31), 16198-16205. https://doi.org/10.1039/c5ta03528g.

(52) Wang, J.; Wang, Y.; Seo, D. H.; Shi, T.; Chen, S.; Tian, Y.; Kim, H.; Ceder, G. A HighEnergy NASICON-Type Cathode Material for Na-Ion Batteries-Supporiting. Adv. Energy Mater. 2020, 10 (10). https://doi.org/10.1002/aenm.201903968.

(53) Lalère, F.; Seznec, V.; Courty, M.; Chotard, J. N.; Masquelier, C. Coupled X-Ray Diffraction and Electrochemical Studies of the Mixed Ti/V-Containing NASICON: $\mathrm{Na}_{2} \mathrm{TiV}\left(\mathrm{PO}_{4}\right)_{3}$. J. Mater. Chem. A 2018, 6 (15), 6654-6659. https://doi.org/10.1039/c7ta10689k.

(54) Bianchini, M.; Ateba-Mba, J. M.; Dagault, P.; Bogdan, E.; Carlier, D.; Suard, E.; Masquelier, C.; Croguennec, L. Multiple Phases in the $\varepsilon-\mathrm{VPO}_{4} \mathrm{O}-\mathrm{LiVPO}_{4} \mathrm{O}-\mathrm{Li}_{2} \mathrm{VPO}_{4} \mathrm{O}$ System: A Combined Solid State Electrochemistry and Diffraction Structural Study. J. Mater. Chem. A 2014, 2 (26), 10182-10192. https://doi.org/10.1039/c4ta01518e.

(55) Masquelier, C.; Wurm, C.; Rodríguez-Carvajal, J.; Gaubicher, J.; Nazar, L. A Powder Neutron Diffraction Investigation of the Two Rhombohedral NASICON Analogues: $\gamma$ $\mathrm{Na}_{3} \mathrm{Fe}_{2}\left(\mathrm{PO}_{4}\right)_{3}$ and $\mathrm{Li}_{3} \mathrm{Fe}_{2}\left(\mathrm{PO}_{4}\right)_{3}$. Chem. Mater. 2000, 12 (2), 525-532. https://doi.org/10.1021/cm991138n.

(56) Liu, R.; Xu, G.; Li, Q.; Zheng, S.; Zheng, G.; Gong, Z.; Li, Y.; Kruskop, E.; Fu, R.; Chen, Z.; et al. Exploring Highly Reversible 1.5-Electron Reactions $\left(\mathrm{V}^{3+} / \mathrm{V}^{4+} / \mathrm{V}^{5+}\right)$ in $\mathrm{Na}{ }_{3} \mathrm{VCr}\left(\mathrm{PO}_{4}\right)_{3}$ Cathode for Sodium-Ion Batteries . ACS Appl. Mater. Interfaces 2017, 9 (50), 4363243639. https://doi.org/10.1021/acsami.7b13018.

(57) Gaubicher, J.; Wurm, C.; Goward, G.; Masquelier, C.; Nazar, L. Rhombohedral Form of $\mathrm{Li}_{3} \mathrm{~V}_{2}\left(\mathrm{PO}_{4}\right)_{3}$ as a Cathode in Li-lon Batteries. Chem. Mater. 2000, 12 (11), 3240-3242. https://doi.org/10.1021/cm000345g. 


\title{
Supplementary Information
}

\section{Crystal Structure of the Intermediate $\mathrm{Na}_{2} \mathrm{~V}_{2}\left(\mathrm{PO}_{4}\right)_{3}$ Phase and Electrochemical Reaction Mechanisms in $\mathrm{Na}_{x} \mathrm{~V}_{2}\left(\mathrm{PO}_{4}\right)_{3}(1 \leq \mathrm{x} \leq 4)$ System}

\author{
Sunkyu Park ${ }^{1,2,3}$, Ziliang Wang ${ }^{4}$, Zeyu Deng ${ }^{4}$, lona Moog ${ }^{3}$, Pieremanuele \\ Canepa ${ }^{4,5 *}$, François Fauth ${ }^{6}$, Dany Carlier ${ }^{2,7}$, Laurence Croguennec ${ }^{2,7}$, \\ Christian Masquelier ${ }^{1,7}$ and Jean-Noël Chotard $1,7, \&$
}

${ }^{1}$ Laboratoire de Réactivité et de Chimie des Solides, Université de Picardie Jules Verne, CNRS-UMR 7314, F-80039 Amiens Cedex 1, France

${ }^{2}$ CNRS, Univ. Bordeaux, Bordeaux INP, ICMCB UMR 5026, F-33600 Pessac, France

${ }^{3}$ TIAMAT, 15 Rue Baudelocque, 80000 Amiens

${ }^{4}$ Department of Materials Science and Engineering, National University of Singapore, Singapore 117575, Singapore

${ }^{5}$ Chemical and Biomolecular Engineering, National University of Singapore, 4 Engineering Drive 4, Singapore 117585

${ }^{6}$ CELLS-ALBA Synchrotron, Cerdanyola del Vallès, E-08290 Barcelona, Spain ${ }^{7} R S 2 E$, Réseau Français sur le Stockage Electrochimique de l'Energie, FR CNRS 3459, F-80039 Amiens Cedex 1, France

Corresponding authors:

*pcanepa@nus.edu.sg \&jean-noel.chotard@u-picardie.fr 

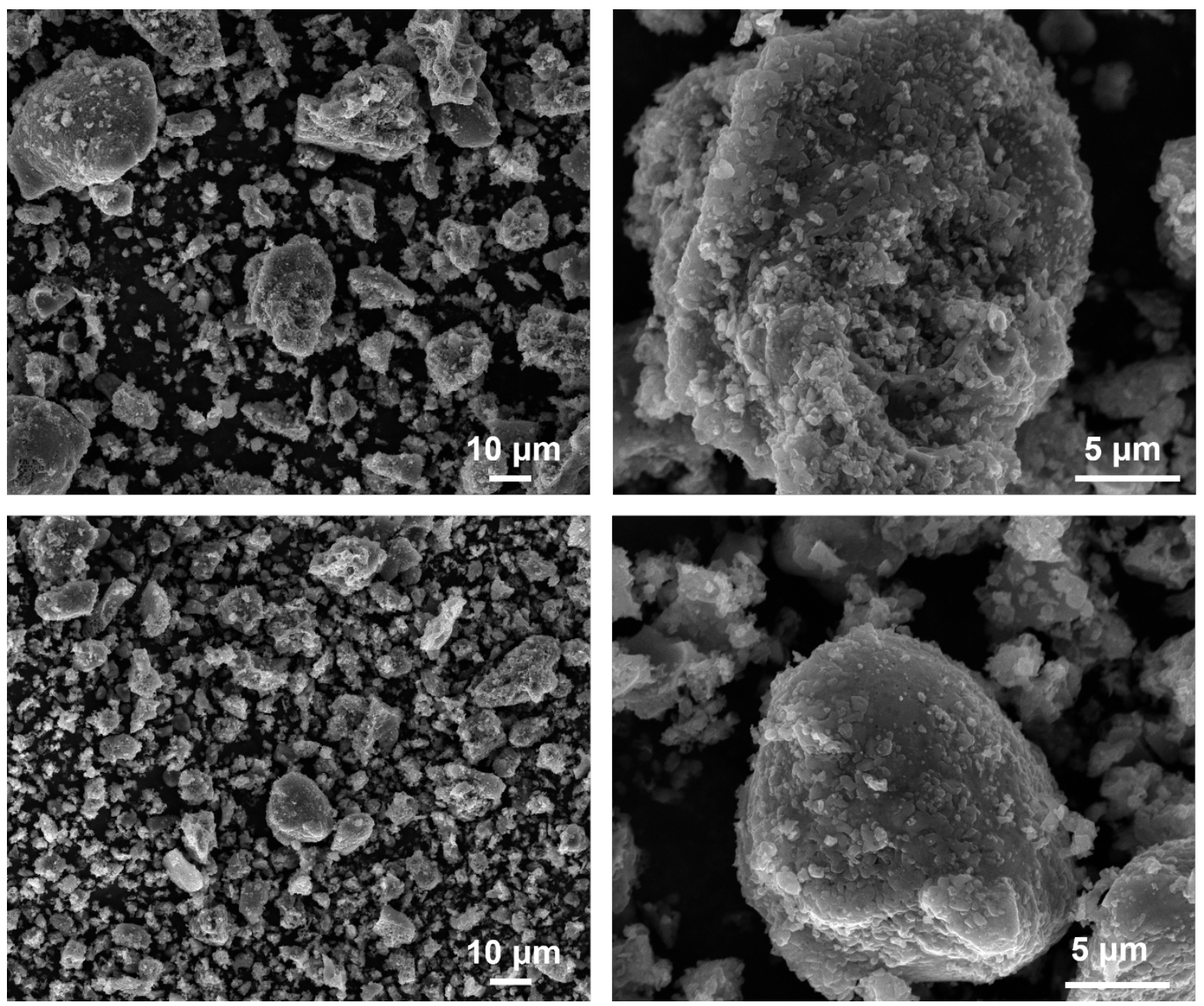

Figure S1. SEM images of the as-synthesized $\mathrm{Na}_{3} \mathrm{~V}_{2}\left(\mathrm{PO}_{4}\right)_{3}$ powder. 


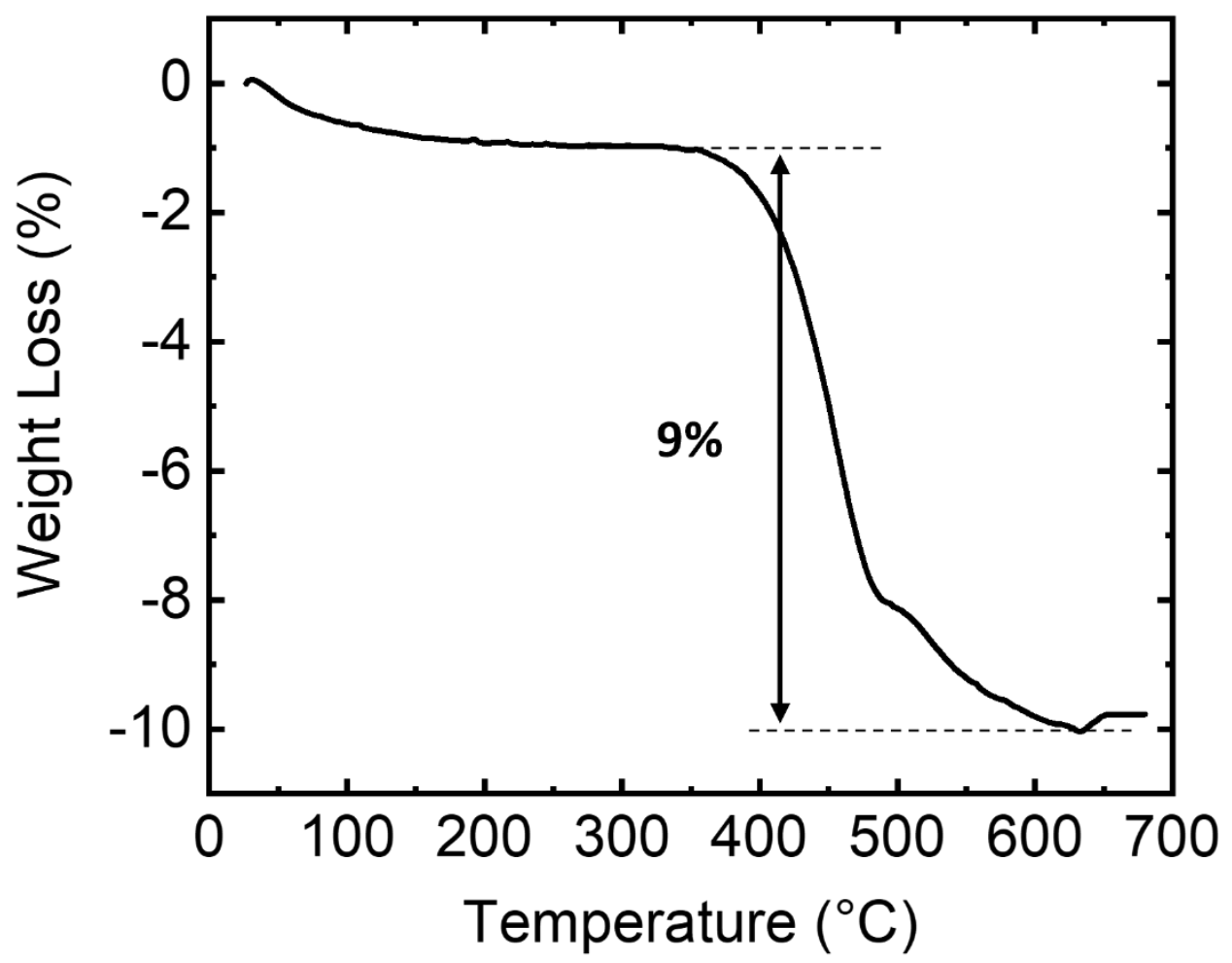

Figure S2. TGA data of the as-synthesized $\mathrm{Na}_{3} \mathrm{~V}_{2}\left(\mathrm{PO}_{4}\right)_{3}$ powder. 


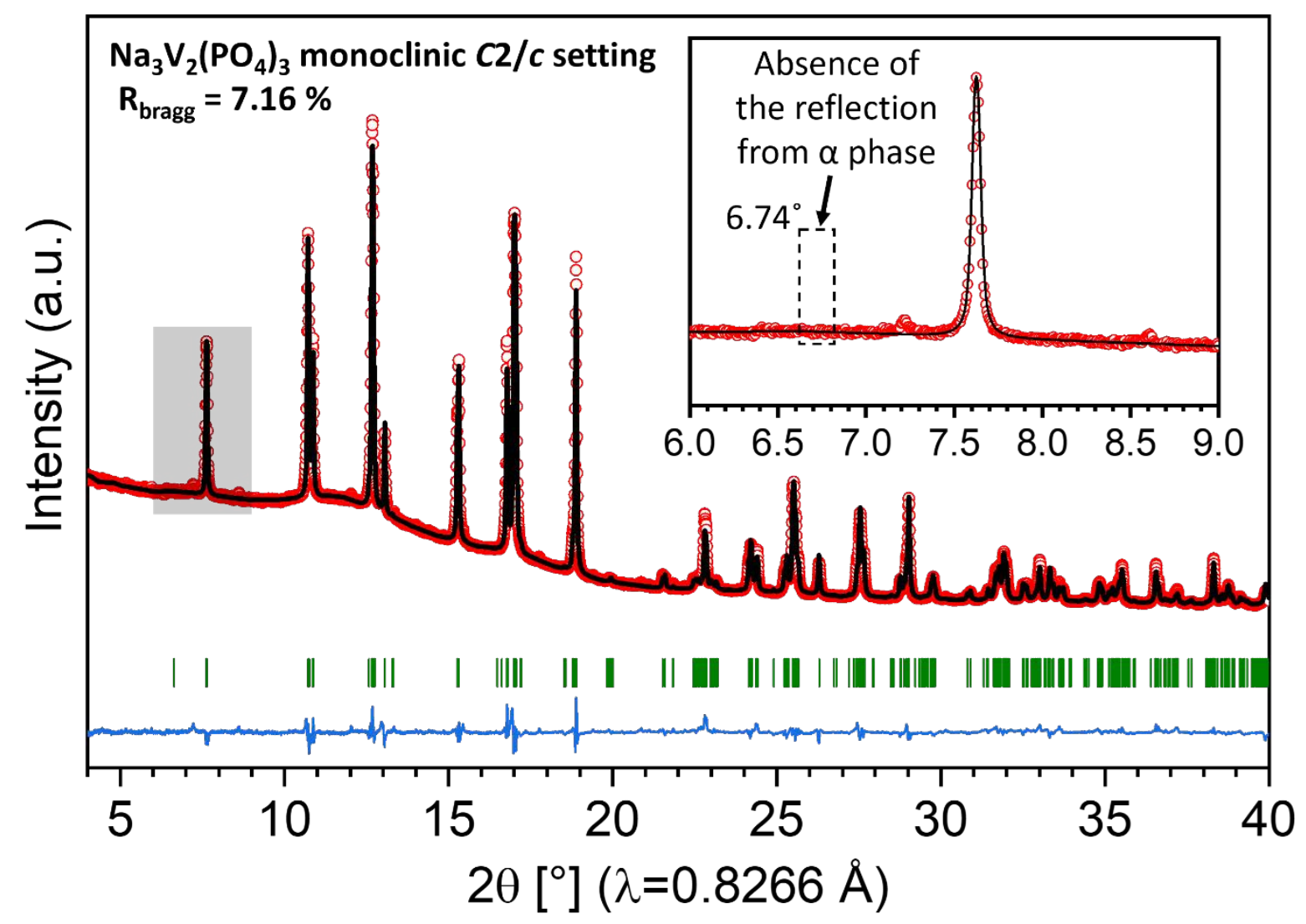

Figure S3. Rietveld refinement results of the as-synthesized $\mathrm{Na}_{3} \mathrm{~V}_{2}\left(\mathrm{PO}_{4}\right)_{3}$ powder at $298 \mathrm{~K}$, highlighting that the $\alpha$ phase structure can be excluded here as reflection at $6.74^{\circ}$ (a clear signature from the $\alpha$ phase) was not observed. 


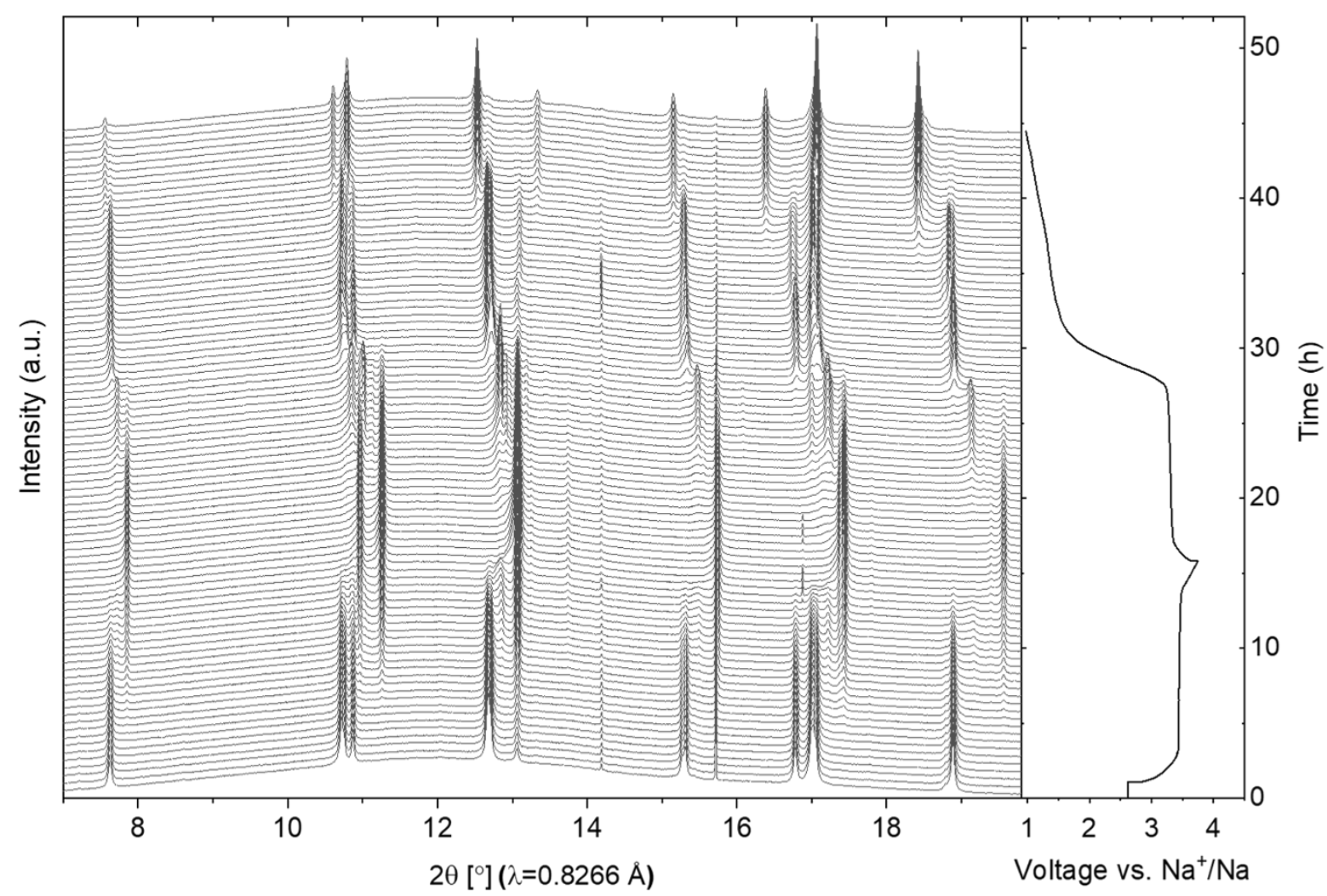

Figure S4. Wider $2 \theta$ ranged operando SPXRD patterns of $\mathrm{Na}_{3} \mathrm{~V}_{2}\left(\mathrm{PO}_{4}\right)_{3}$ during first cycle with a voltage window of $1.0-3.75 \mathrm{~V}$ vs. $\mathrm{Na}^{+} / \mathrm{Na}$ at the $\mathrm{C}$-rate of $0.11 \mathrm{C}\left(=1 \mathrm{Na}^{+}\right.$in $\left.9 \mathrm{~h}\right)$. The same data with the counter plot with the narrower $2 \theta$ range of $7.4-8.0^{\circ}$ is shown in Figure 2 . 


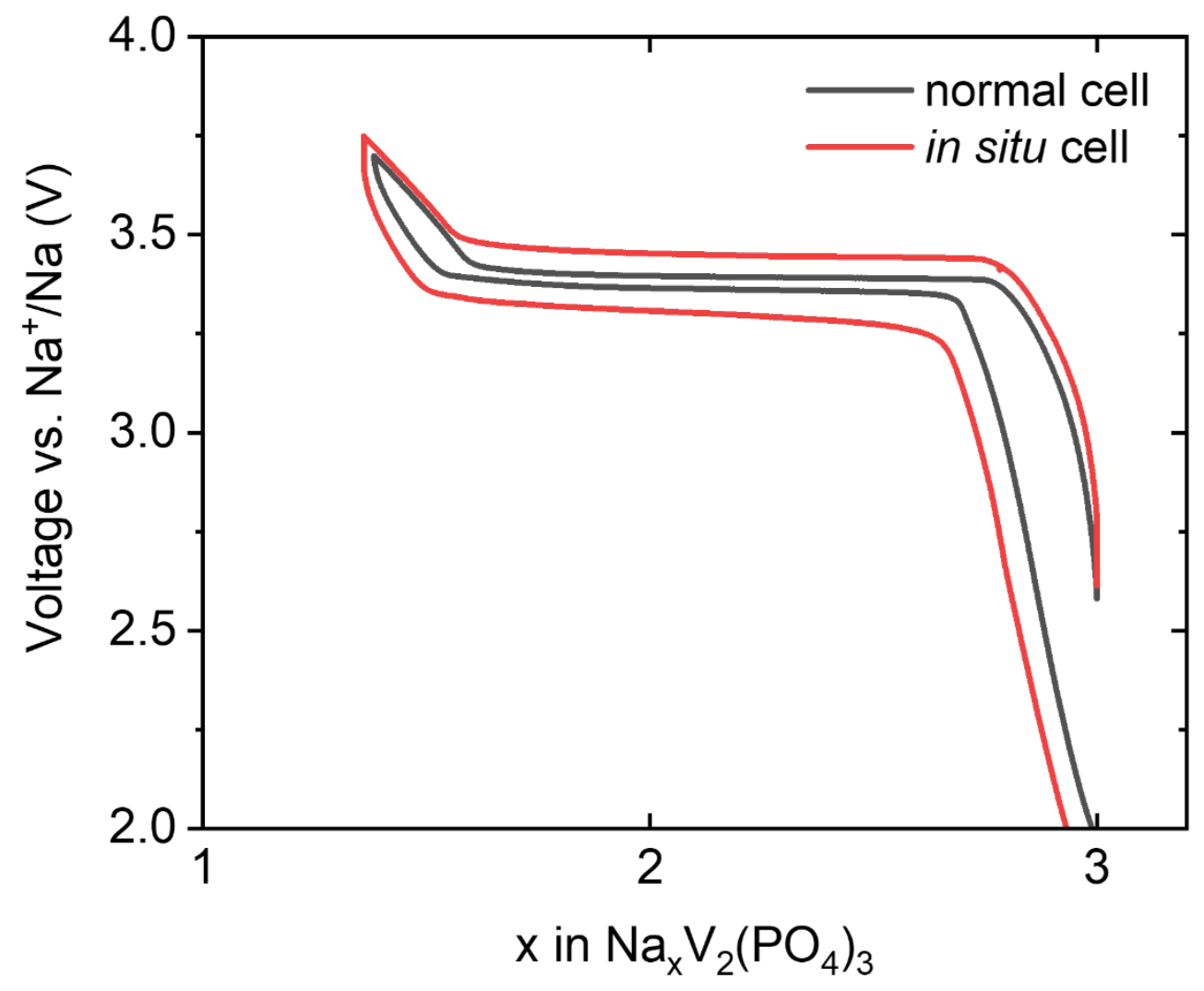

Figure S5. Comparison of a polarization between the first in situ cell (shown in Figure 2) and a normal coin cell cycled with the same C-rate of $0.11 \mathrm{C}$. The assembly of the normal coin cell is done with the same way as the in situ coin cell. The polarization of the in situ coin cell is about $150 \mathrm{mV}$ while that of the normal coin cell is about $30 \mathrm{mV}$. 

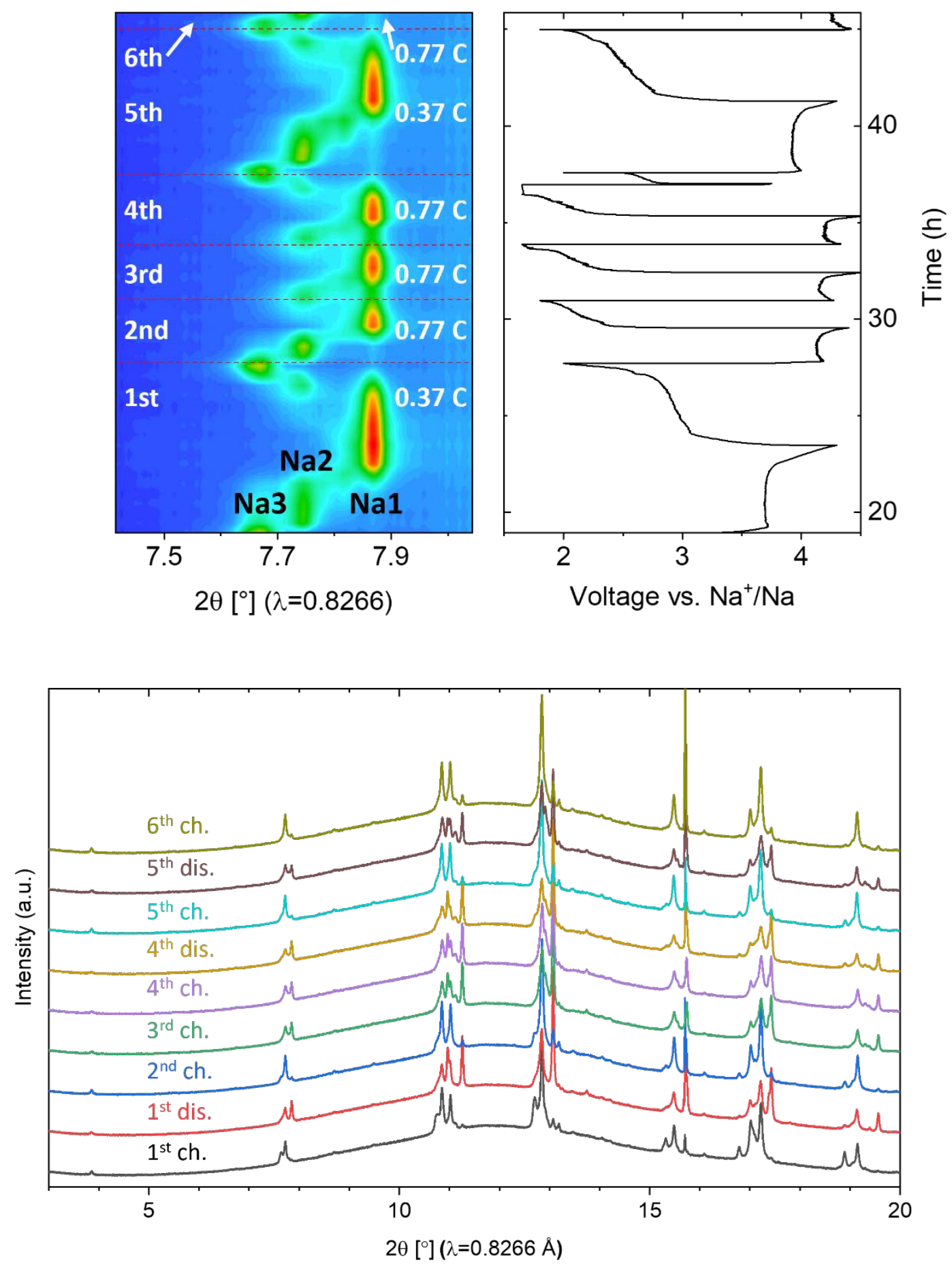

Figure S6 Top: Operando SPXRD measurements performed upon cycling of $\mathrm{Na}_{3} \mathrm{~V}_{2}\left(\mathrm{PO}_{4}\right)_{3}$ as positive electrode material in a half-cell versus $\mathrm{Na}$ metal, during six cycles at C-rates of 0.37 or $0.77 \mathrm{C}$. The voltage windows of each cycle are given in details in Table S2. Bottom: the SPXRD patterns containing the most $\mathrm{Na}_{2} \mathrm{~V}_{2}\left(\mathrm{PO}_{4}\right)_{3}$ phase during each cycle. Note that the $\mathrm{Na}_{3} \mathrm{~V}_{2}\left(\mathrm{PO}_{4}\right)_{3}$ phase during $2^{\text {nd }}$ and $3^{\text {rd }}$ discharge was not observed as data point missing (fewer data points) due to higher C-rate. 
Table S1. Changes in voltage windows and C-rates during operando XRD measurements performed upon cycling of the second cell (Figure S5). The measurement was stopped in the middle of charge during the sixth cycle.

\begin{tabular}{cccc} 
Cycle number & C-rate & $\begin{array}{c}\text { Lower cut-off } \\
\text { (V) }\end{array}$ & $\begin{array}{c}\text { Upper cut-off } \\
\text { (V) }\end{array}$ \\
1 & 0.37 C & 2 & 4.3 \\
2 & 0.77 C & 1.8 & 4.4 \\
3 & 0.77 C & 1.65 & 4.5 \\
4 & 0.77 C & 1.65 & 4.5 \\
5 & 0.37 C & 2 & 4.3 \\
$6^{*}$ & 0.77 C & 1.65 & 4.5 \\
\hline
\end{tabular}




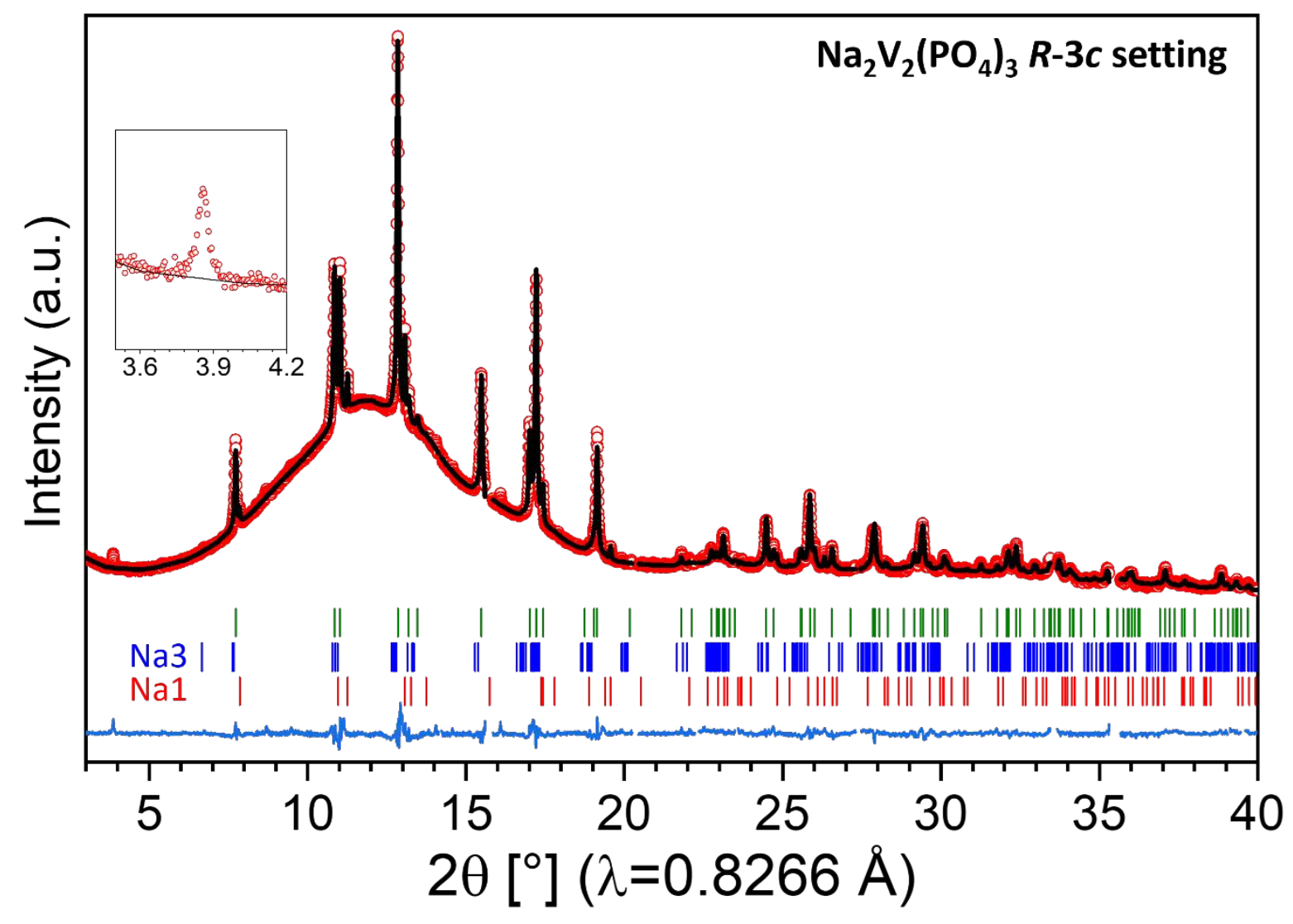

Figure S7. Rietveld refinement results of $\mathrm{Na}_{2} \mathrm{~V}_{2}\left(\mathrm{PO}_{4}\right)_{3}$ with the space group $R 3 \mathrm{c}$. The reflection at $3.85^{\circ}$ is not explained with the current structural model. 


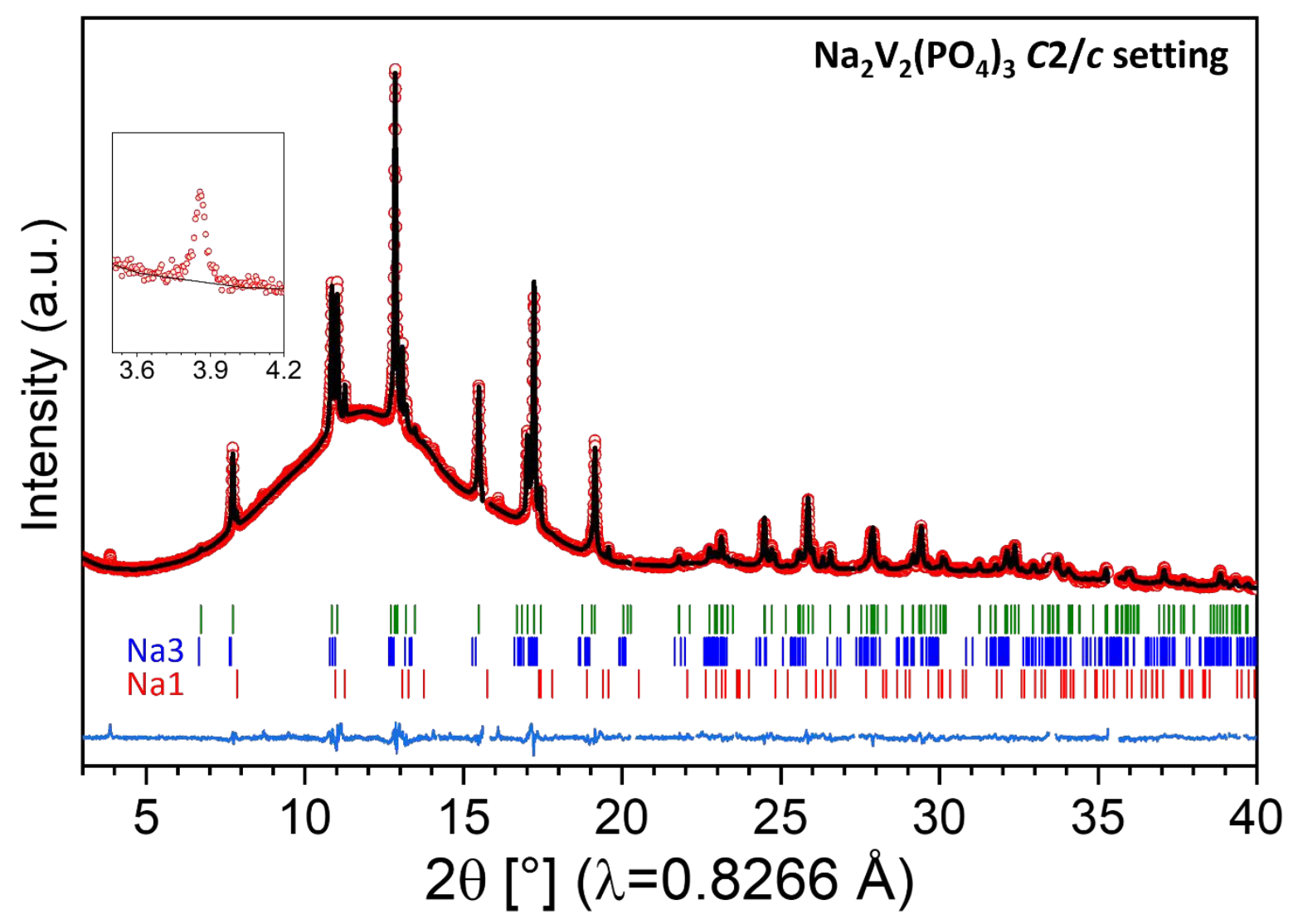

Figure S8. Rietveld refinement results of $\mathrm{Na}_{2} \mathrm{~V}_{2}\left(\mathrm{PO}_{4}\right)_{3}$ with the space group $\mathrm{C2} / \mathrm{c}$. The reflection at $3.85^{\circ}$ is not explained with the current structural model. 
Table S2. V-O bond distances obtained from Rietveld refinement of the four compositions $\mathrm{Na}_{x} \mathrm{~V}_{2}\left(\mathrm{PO}_{4}\right)_{3}(\mathrm{x}=1,2,3$, and 4).

\begin{tabular}{|c|c|c|c|c|c|c|c|c|c|c|c|c|c|c|}
\hline \multicolumn{3}{|c|}{$\begin{array}{c}\mathrm{Na}_{4} \mathrm{~V}_{2}\left(\mathrm{PO}_{4}\right)_{3} \\
R 3 \mathrm{C}\end{array}$} & \multicolumn{3}{|c|}{$\begin{array}{c}\mathrm{Na}_{3} \mathrm{~V}_{2}\left(\mathrm{PO}_{4}\right)_{3} \\
\mathrm{C} 2 / \mathrm{c}\end{array}$} & \multicolumn{3}{|c|}{$\begin{array}{c}\mathrm{Na}_{2} \mathrm{~V}_{2}\left(\mathrm{PO}_{4}\right)_{3} \\
\mathrm{P2}_{1} / \mathrm{c} \text { (Model 1) }\end{array}$} & \multicolumn{3}{|c|}{$\begin{array}{c}\mathrm{Na}_{2} \mathrm{~V}_{2}\left(\mathrm{PO}_{4}\right)_{3} \\
\mathrm{P} 2 / \mathrm{c}(\mathrm{Model} 2)\end{array}$} & \multicolumn{3}{|c|}{$\begin{array}{c}\mathrm{Na}_{1} \mathrm{~V}_{2}\left(\mathrm{PO}_{4}\right)_{3} \\
R 3 \mathrm{c}\end{array}$} \\
\hline \multirow[t]{14}{*}{$V(1)$} & $O(1)$ & $2.065(14) \times 3$ & $V(1)$ & $\mathrm{O}(1)$ & $1.89(3)$ & $V(1 a)$ & $O(1 b)$ & $2.05(9)$ & $V(1 a)$ & $O(1 b)$ & $1.98(9)$ & $V(1)$ & $O(1)$ & $1.931(16) \times 3$ \\
\hline & $O(2)$ & $2.087(14) \times 3$ & & $\mathrm{O}(2)$ & $2.00(4)$ & & $O(1 d)$ & $1.70(10)$ & & $O(1 d)$ & $1.62(9)$ & & $O(2)$ & $1.88(2) \times 3$ \\
\hline & & & & $\mathrm{O}(3)$ & $2.01(3)$ & & $\mathrm{O}(1 \mathrm{e})$ & $1.93(7)$ & & $\mathrm{O}(1 \mathrm{e})$ & $1.87(6)$ & & & \\
\hline & & & & $\mathrm{O}(4)$ & $2.04(4)$ & & $O(2 b)$ & $2.17(10)$ & & $O(2 b)$ & $2.18(10)$ & & & \\
\hline & & & & $\mathrm{O}(5)$ & $2.09(3)$ & & $\mathrm{O}(2 \mathrm{c})$ & $2.03(8)$ & & $O(2 c)$ & $1.801(5)$ & & & \\
\hline & & & & $\mathrm{O}(6)$ & $2.06(4)$ & & $O(2 f)$ & $2.06(9)$ & & $O(2 f)$ & $2.06(8)$ & & & \\
\hline & & & & & & avg. $V$ & 1a)-0 & $1.99(9)$ & avg. $\mathrm{V}$ & 1a) -0 & $1.92(8)$ & & & \\
\hline & & & & & & $V(1 b)$ & $O(1 a)$ & $2.04(9)$ & $V(1 b)$ & $\mathrm{O}(1 \mathrm{a})$ & $2.10(8)$ & & & \\
\hline & & & & & & & $\mathrm{O}(1 \mathrm{c})$ & $1.85(10)$ & & $O(1 c)$ & $1.91(10)$ & & & \\
\hline & & & & & & & $O(1 f)$ & $2.17(7)$ & & $O(1 f)$ & $2.24(5)$ & & & \\
\hline & & & & & & & $O(2 a)$ & $2.01(10)$ & & $\mathrm{O}(2 \mathrm{a})$ & $2.04(8)$ & & & \\
\hline & & & & & & & $O(2 d)$ & $1.82(8)$ & & $O(2 d)$ & $1.95(7)$ & & & \\
\hline & & & & & & & $O(2 e)$ & $2.08(11)$ & & $O(2 e)$ & $1.99(8)$ & & & \\
\hline & & & & & & avg. $V$ & 1b)-0 & $1.99(9)$ & avg. $V$ & 1b) -0 & $2.04(8)$ & & & \\
\hline Avg. & & $2.076(14)$ & & & $2.02(4)$ & & & $1.99(9)$ & & & $1.98(8)$ & & & $1.91(2)$ \\
\hline
\end{tabular}


Table S3. Refined structural parameters of the intermediate phase $\mathrm{Na}_{2} \mathrm{~V}_{2}\left(\mathrm{PO}_{4}\right)_{3}$ using the space group $P 2 / C$ (Model 2). a Refined and fixed at the last stages of refinement.

\begin{tabular}{|c|c|c|c|c|c|c|}
\hline \multicolumn{7}{|c|}{$\begin{array}{c}\mathrm{Na}_{\mathbf{2}} \mathbf{V}_{\mathbf{2}}\left(\mathrm{PO}_{4}\right)_{\mathbf{3}} \\
\text { Space group: } P 2 / c(\# 13) ; Z=4 \\
\mathrm{a}=15.2380(5) \AA ; \quad b=8.6090(5) \AA ; c=8.7390(4) ; b=126.289(5) \\
\mathrm{V}=924.05(7) \AA^{3} ; \mathrm{V} / \mathrm{Z}=231.01(2) \AA^{3} \\
R_{\mathrm{wp}}=12.8 \% ; R_{\mathrm{p}}=18.0 \% ; R_{\mathrm{bragg}}=7.50 \%\end{array}$} \\
\hline Atom & Wyckoff position & $x / a$ & $y / b$ & $z / c$ & Uiso, $\AA^{2}$ & Occ. \\
\hline$V(1 a)$ & $4 g$ & $0.600(2)$ & $0.243(4)$ & $0.649(4)$ & $0.026(3)$ & 1 \\
\hline$V(1 b)$ & $4 g$ & $0.108(2)$ & $0.741(4)$ & $0.645(4)$ & $0.026(3)$ & 1 \\
\hline$P(1 a)$ & $4 g$ & $0.8498(10)$ & $0.113(2)$ & $0.932(2)$ & $0.029(3)$ & 1 \\
\hline$P(1 b)$ & $4 g$ & $0.3569(10)$ & $0.605(2)$ & $0.958(2)$ & $0.029(3)$ & 1 \\
\hline $\mathrm{P}(2 \mathrm{a})$ & $2 \mathrm{e}$ & 0 & $0.534(2)$ & 0.25 & $0.029(3)$ & 1 \\
\hline$P(2 b)$ & $2 f$ & 0.5 & $0.021(2)$ & 0.25 & $0.029(3)$ & 1 \\
\hline$O(1 a)$ & $4 g$ & $0.143(6)$ & $0.149(10)$ & $0.389(7)$ & $0.012(3)$ & 1 \\
\hline$O(1 b)$ & $4 g$ & $0.660(7)$ & $0.643(10)$ & $0.389(10)$ & $0.012(3)$ & 1 \\
\hline $\mathrm{O}(2 \mathrm{a})$ & $4 g$ & $0.072(6)$ & $0.451(10)$ & $0.204(10)$ & $0.012(3)$ & 1 \\
\hline $\mathrm{O}(2 \mathrm{~b})$ & $4 g$ & $0.553(6)$ & $0.888(5)$ & $0.214(10)$ & $0.012(3)$ & 1 \\
\hline$O(3 a)$ & $4 g$ & $0.458(4)$ & $0.678(10)$ & $0.990(10)$ & $0.012(3)$ & 1 \\
\hline$O(3 b)$ & $4 g$ & $0.937(4)$ & $0.184(7)$ & $0.919(10)$ & $0.012(3)$ & 1 \\
\hline $\mathrm{O}(4 \mathrm{a})$ & $4 g$ & $0.157(7)$ & $0.064(2)$ & $0.082(10)$ & $0.012(3)$ & 1 \\
\hline$O(4 b)$ & $4 g$ & $0.635(7)$ & $0.573(2)$ & $0.020(4)$ & $0.012(3)$ & 1 \\
\hline$O(5 a)$ & $4 g$ & $0.734(3)$ & $0.840(10)$ & $0.265(7)$ & $0.012(3)$ & 1 \\
\hline$O(5 b)$ & $4 g$ & $0.259(5)$ & $0.325(10)$ & $0.273(7)$ & $0.012(3)$ & 1 \\
\hline$O(6 a)$ & $4 g$ & $0.085(6)$ & $0.364(10)$ & $0.920(7)$ & $0.012(3)$ & 1 \\
\hline$O(6 b)$ & $4 g$ & $0.581(6)$ & $0.882(10)$ & $0.929(7)$ & $0.012(3)$ & 1 \\
\hline $\mathrm{Na}(1)$ & $4 g$ & $0.275(4)$ & $0.280(7)$ & $0.050(7)$ & $0.030(13)$ & $0.98(3)$ \\
\hline $\mathrm{Na}\left(2 \mathrm{a}_{1}\right)$ & $4 g$ & $0.695^{a}$ & $0.937^{a}$ & $0.603^{a}$ & $0.030(13)$ & $0.17(7)$ \\
\hline $\mathrm{Na}\left(2 \mathrm{a}_{2}\right)$ & $4 g$ & $0.172^{\mathrm{a}}$ & $0.446^{a}$ & $0.570^{\mathrm{a}}$ & $0.030(13)$ & $0.21(7)$ \\
\hline $\mathrm{Na}\left(2 \mathrm{~b}_{1}\right)$ & $2 e$ & 0 & $0.916(10)$ & 0.25 & $0.030(13)$ & $0.63(11)$ \\
\hline $\mathrm{Na}\left(2 \mathrm{~b}_{2}\right)$ & $2 f$ & 0.5 & $0.362(13)$ & 0.25 & $0.030(13)$ & $0.68(11)$ \\
\hline
\end{tabular}




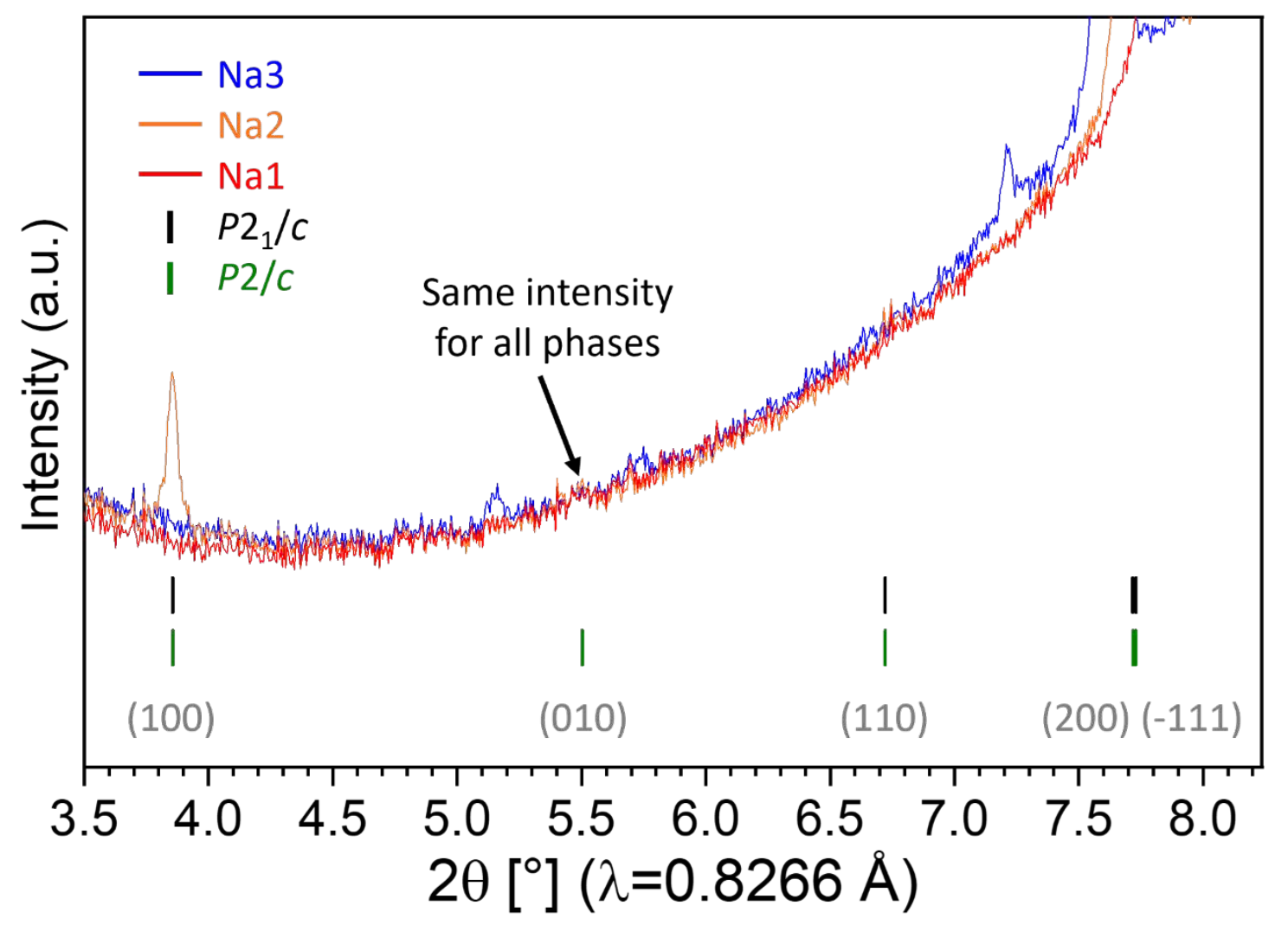

Figure S9. Comparison of the space group $P 2_{1} / c$ and $P 2 / c$ for the structural determination of $\mathrm{Na}_{2} \mathrm{~V}_{2}\left(\mathrm{PO}_{4}\right)_{3}$ phase. The same intensity for the possible (010) reflection (from the $P 2 / c$ structural model) was observed in the XRD patterns of $\mathrm{Na}_{3} \mathrm{~V}_{2}\left(\mathrm{PO}_{4}\right)_{3}, \mathrm{Na}_{2} \mathrm{~V}_{2}\left(\mathrm{PO}_{4}\right)_{3}$, and $\mathrm{Na}_{1} \mathrm{~V}_{2}\left(\mathrm{PO}_{4}\right)_{3}$, suggesting it is not a peak but noisy background. 


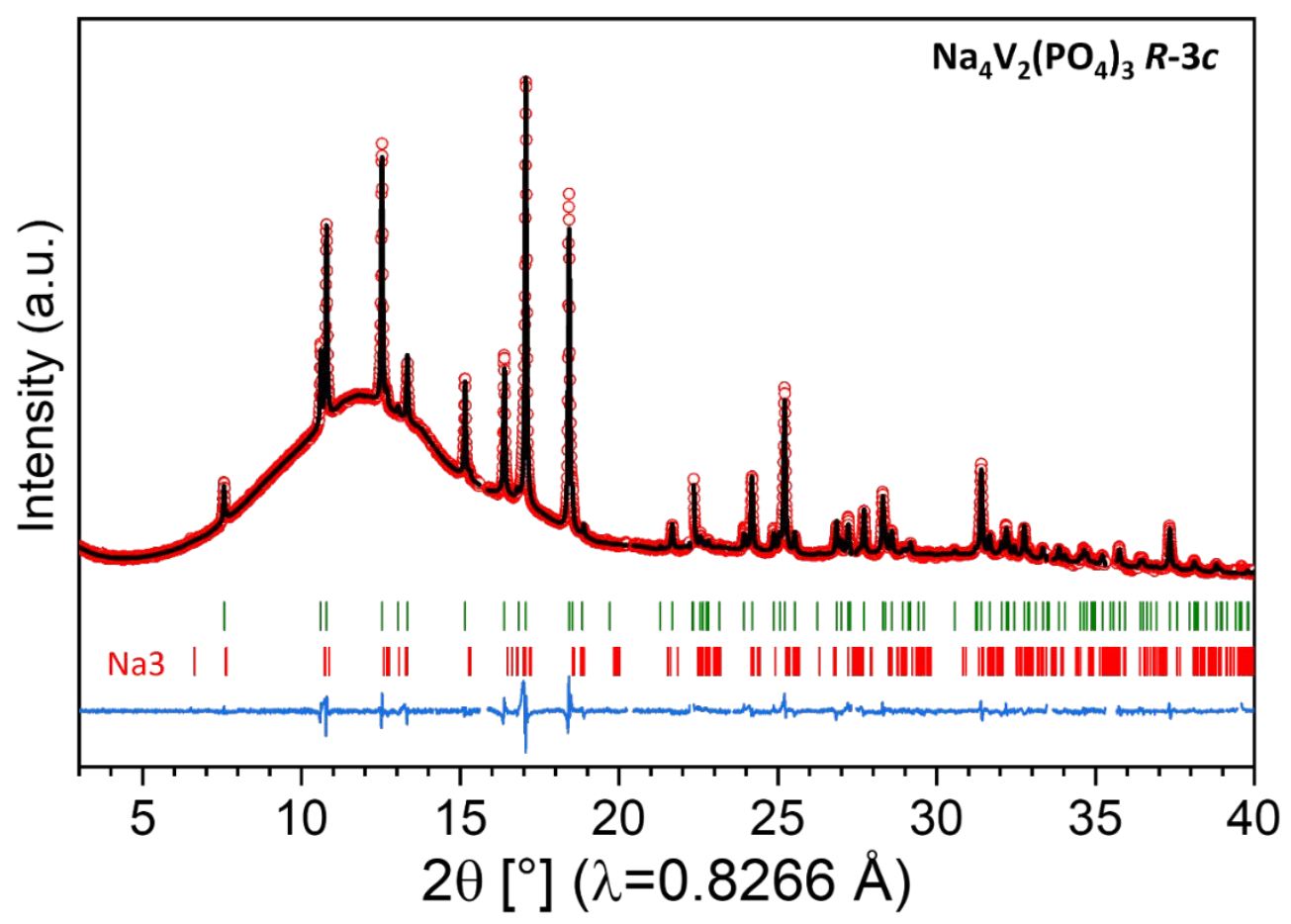

Figure S10. Rietveld refinement results of $\mathrm{Na}_{4} \mathrm{~V}_{2}\left(\mathrm{PO}_{4}\right)_{3}$. The XRD pattern was obtained from operando measurements. The contributions from $\mathrm{Na}$ metal and Al foil are removed

Table S4. Refined structural parameters of the $\mathrm{Na}_{4} \mathrm{~V}_{2}\left(\mathrm{PO}_{4}\right)_{3}$ using the space group $R 3 c$.

\begin{tabular}{|c|c|c|c|c|c|c|}
\hline \multicolumn{7}{|c|}{$\begin{array}{c}\mathrm{Na}_{\mathbf{4}} \mathbf{V}_{\mathbf{2}}\left(\mathbf{P O}_{4}\right)_{\mathbf{3}} \\
\text { Space group: } R 3 c(\# 167) ; Z=6 \\
a=8.94302(10) \AA ; c=21.3609(4) \AA ; c / a=2.389 \\
V=1479.51(4) \AA^{3} ; V / Z=246.585(7) \AA^{3} \\
R_{\mathrm{wp}}=14.1 \% ; R_{\mathrm{p}}=19.5 \% ; R_{\text {bragg }}=4.2 \%\end{array}$} \\
\hline Atom & $\begin{array}{l}\text { Wyckoff } \\
\text { position }\end{array}$ & $x / a$ & $y / b$ & $z / c$ & Uiso, $\AA^{2}$ & Occ. \\
\hline $\mathrm{V}(1)$ & $12 c$ & 0 & 0 & $0.1467(3)$ & $0.014(2)$ & 1 \\
\hline$P(1)$ & $18 \mathrm{e}$ & $0.2970(11)$ & 0 & 0.25 & $0.021(4)$ & 1 \\
\hline $\mathrm{Na}(1)$ & $6 b$ & 0 & 0 & 0 & $0.031(9)$ & $0.97(4)$ \\
\hline $\mathrm{Na}(2)$ & $18 \mathrm{e}$ & $0.6461(14)$ & 0 & 0.25 & $0.021(8)$ & $0.92(2)$ \\
\hline $\mathrm{O}(1)$ & $36 f$ & $0.013(2)$ & $0.2099(14)$ & $0.1921(5)$ & $0.020(5)$ & 1 \\
\hline $\mathrm{O}(2)$ & $36 f$ & $0.1827(14)$ & $0.1713(14)$ & $0.0833(7)$ & $0.024(4)$ & 1 \\
\hline
\end{tabular}




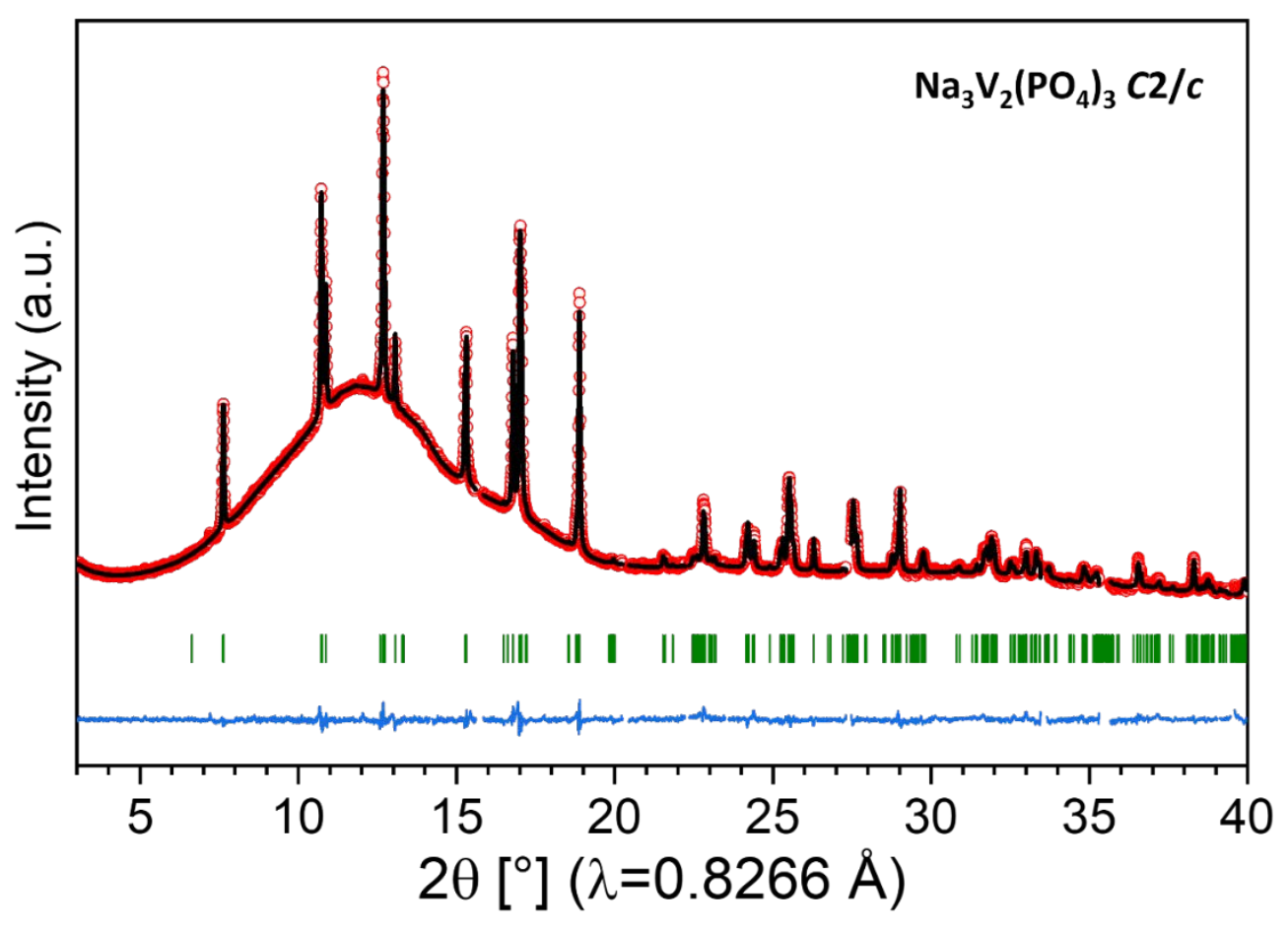

Figure S11. Rietveld refinement results of $\mathrm{Na}_{3} \mathrm{~V}_{2}\left(\mathrm{PO}_{4}\right)_{3}$. The XRD pattern was obtained from operando measurements. The contributions from $\mathrm{Na}$ metal and Al foil are removed 
Table S5. Refined structural parameters of the intermediate phase $\mathrm{Na}_{3} \mathrm{~V}_{2}\left(\mathrm{PO}_{4}\right)_{3}$ using the space group $C 2 / c$. The XRD pattern was obtained from operando measurements.

\begin{tabular}{|c|c|c|c|c|c|c|}
\hline \multicolumn{7}{|c|}{$\begin{array}{c}\mathrm{Na}_{\mathbf{3}} \mathbf{V}_{\mathbf{2}}\left(\mathrm{PO}_{4}\right)_{\mathbf{3}} \\
\text { Space group: } C 2 / c(\# 15) ; Z=4 \\
\mathrm{a}=15.4065(3) \AA ; \quad b=8.7288(2) \AA ; c=8.8243(2) ; b=126.1091(16) \\
\mathrm{V}=958.73(4) \AA^{3} ; \mathrm{V} / \mathrm{Z}=239.682(10) \AA^{3} \\
R_{\mathrm{wp}}=11.2 \% ; R_{\mathrm{p}}=17.5 \% ; R_{\text {bragg }}=7.17 \%\end{array}$} \\
\hline Atom & $\begin{array}{l}\text { Wyckoff } \\
\text { position }\end{array}$ & $x / a$ & $y / b$ & $z / c$ & Uiso, $\AA^{2}$ & Occ. \\
\hline $\mathrm{V}(1)$ & $8 f$ & $0.6029(6)$ & $0.253(3)$ & $0.6500(14)$ & $0.015(2)$ & 1 \\
\hline$P(1)$ & $8 f$ & $0.8514(11)$ & $0.0999(14)$ & $0.9620(14)$ & $0.021(3)$ & 1 \\
\hline$P(2)$ & $4 e$ & 0 & $0.532(2)$ & 0.25 & $0.021(3)$ & 1 \\
\hline$O(1)$ & $8 f$ & $0.138(2)$ & $0.126(4)$ & $0.357(3)$ & $0.011(2)$ & 1 \\
\hline$O(2)$ & $8 f$ & $0.0763(18)$ & $0.450(3)$ & $0.221(3)$ & $0.011(2)$ & 1 \\
\hline$O(3)$ & $8 f$ & $0.4510(18)$ & $0.670(3)$ & $0.987(4)$ & $0.011(2)$ & 1 \\
\hline$O(4)$ & $8 f$ & $0.156(2)$ & $0.076(2)$ & $0.066(4)$ & $0.011(2)$ & 1 \\
\hline$O(5)$ & $8 f$ & $0.7587(18)$ & $0.828(4)$ & $0.275(3)$ & $0.011(2)$ & 1 \\
\hline$O(6)$ & $8 f$ & $0.073(2)$ & $0.361(3)$ & $0.919(3)$ & $0.011(2)$ & 1 \\
\hline $\mathrm{Na}(1)$ & $4 c$ & 0.25 & 0.25 & 0 & $0.059(9)$ & $0.679(14)$ \\
\hline $\mathrm{Na}(2 \mathrm{a})$ & $8 f$ & $0.665(2)$ & $0.927(5)$ & $0.634(5)$ & $0.059(9)$ & $0.70(3)$ \\
\hline $\mathrm{Na}(2 \mathrm{~b})$ & $4 \mathrm{e}$ & 0 & $0.877(6)$ & 0.25 & $0.059(9)$ & $0.87(2)$ \\
\hline
\end{tabular}




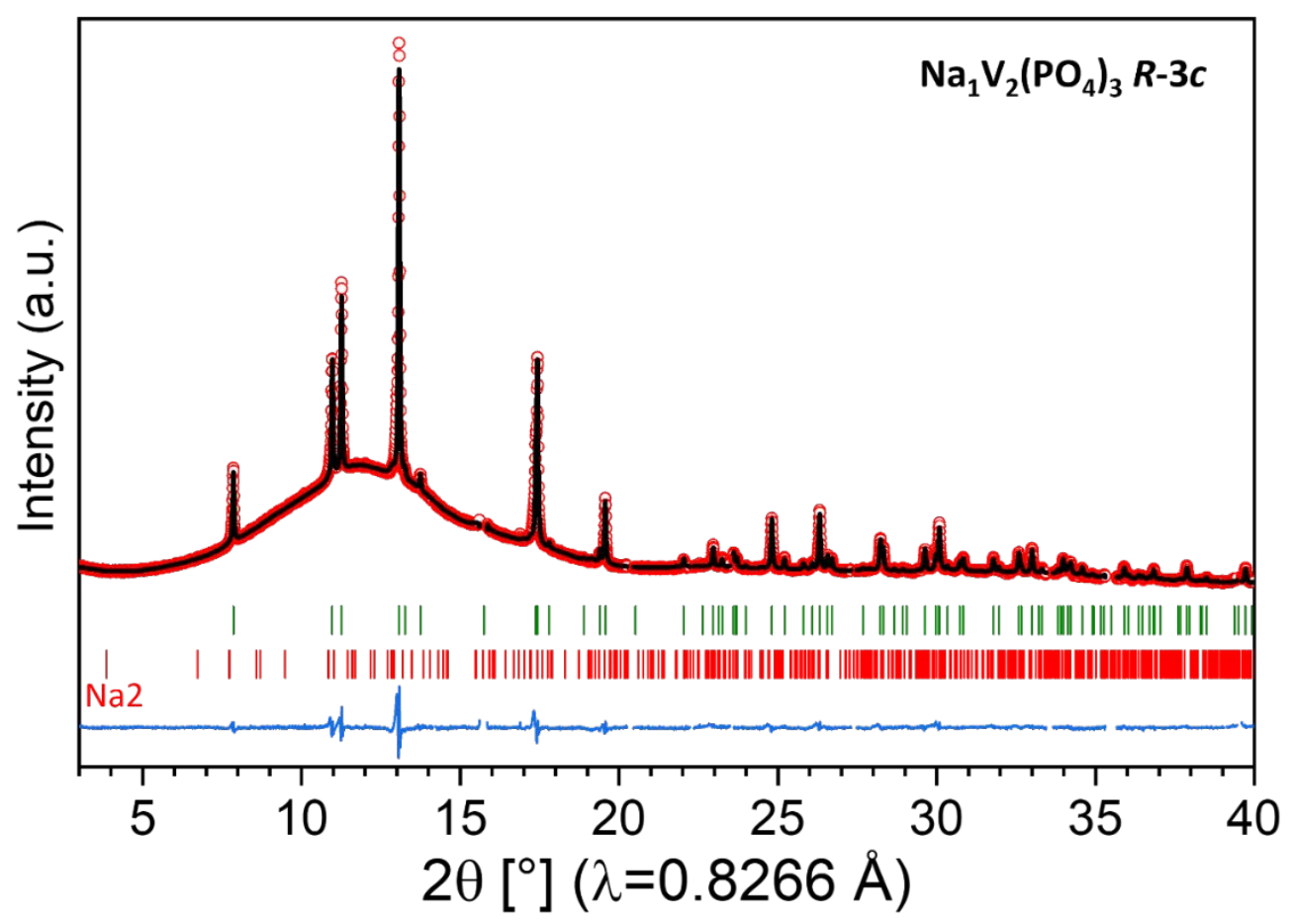

Figure S12. Rietveld refinement results of $\mathrm{Na}_{1} \mathrm{~V}_{2}\left(\mathrm{PO}_{4}\right)_{3}$. The XRD pattern was obtained from operando measurements. The contributions from $\mathrm{Na}$ metal and Al foil are removed.

Table S6. Refined structural parameters of the $\mathrm{Na}_{4} \mathrm{~V}_{2}\left(\mathrm{PO}_{4}\right)_{3}$ using the space group $R 3 \mathrm{c}$.

\begin{tabular}{|c|c|c|c|c|c|c|}
\hline \multicolumn{7}{|c|}{$\begin{array}{c}\mathrm{Na}_{\mathbf{1}} \mathbf{V}_{\mathbf{2}}\left(\mathrm{PO}_{4}\right)_{\mathbf{3}} \\
\text { Space group: } R 3 c(\# 167) ; Z=6 \\
a=8.42631(12) \AA ; c=21.4772(6) \AA ; c / a=2.549 \\
V=1320.63(5) \AA^{3} ; V / Z=220.105(8) \AA^{3} \\
R_{\mathrm{wp}}=15.8 \% ; R_{\mathrm{p}}=24.3 \% ; R_{\text {bragg }}=7.69 \%\end{array}$} \\
\hline Atom & $\begin{array}{l}\text { Wyckoff } \\
\text { position }\end{array}$ & $x / a$ & $y / b$ & $z / c$ & Uiso, $\AA^{2}$ & Occ. \\
\hline $\mathrm{V}(1)$ & $12 c$ & 0 & 0 & $0.1450(4)$ & $0.024(3)$ & 1 \\
\hline$P(1)$ & $18 \mathrm{e}$ & $0.285(1)$ & 0 & 0.25 & $0.023(4)$ & 1 \\
\hline $\mathrm{Na}(1)$ & $6 b$ & 0 & 0 & 0 & $0.034(0)$ & $0.96(4)$ \\
\hline $\mathrm{O}(1)$ & $36 f$ & $0.187(2)$ & $0.160(2)$ & $0.087(1)$ & $0.017(5)$ & 1 \\
\hline$O(2)$ & $36 f$ & $0.023(3)$ & $0.198(2)$ & $0.192(1)$ & $0.014(5)$ & 1 \\
\hline
\end{tabular}

